UNIVERSIDADE DE SÃO PAULO

FACULDADE DE FILOSOFIA, LETRAS E CIÊNCIAS HUMANAS DEPARTAMENTO DE FILOSOFIA

PROGRAMA DE PÓS-GRADUAÇÃO EM FILOSOFIA

Modelagem causal da astronomia antiga

Rodrigo Cristino de Faria 
UNIVERSIDADE DE SÃO PAULO

FACULDADE DE FILOSOFIA, LETRAS E CIÊNCIAS HUMANAS

DEPARTAMENTO DE FILOSOFIA

PROGRAMA DE PÓS-GRADUAÇÃO EM FILOSOFIA

\section{Modelagem causal da astronomia antiga}

Rodrigo Cristino de Faria

Dissertação apresentada ao Programa de Pós-Graduação em Filosofia, do Departamento de Filosofia da Faculdade de Filosofia, Letras e Ciências Humanas da Universidade de São Paulo, sob a orientação do Prof. Dr. Osvaldo Pessoa Jr., como parte dos requisitos para a obtenção do título de Mestre em Filosofia.

São Paulo 
Autorizo a reprodução e divulgação total ou parcial deste trabalho, por qualquer meio, para fins de estudo e pesquisa, desde que citada a fonte.

\section{Catalogação da publicação}

Faculdade de Filosofia, Letras e Ciências Humanas da Universidade de São Paulo Faria, Rodrigo Cristino de.

Modelagem causal da astronomia antiga. São Paulo, 2014.

Dissertação (Mestrado). Universidade de São Paulo, 2014.

1. Astronomia antiga

2. Modelos causais

3.Causalidade 4. historiografia 


\section{Agradecimentos}

Ao professor Osvaldo Pessoa Jr., pelo exemplo do que é ser filósofo e pela paciência quase infinita desde os tempos de iniciação científica.

Aos professores das bancas de qualificação e defesa, pelas leituras atentas do meu texto e pelas sugestões valiosas: Prof. Dra. Sara Albieri, Prof. Dr. Claudemir Tossato e Prof. Dr. Valter Bezerra.

A CAPES, pela bolsa de mestrado.

À minha mãe e à Rita, sine quibus non.

À Marina, pelo amor e pela história.

Deo gloria et imperium in saecula saeculorum. 
felix, qui potuit rerum cognoscere causas.

Virgílio (Geórgicas, II, 490) 


\section{Resumo}

FARIA, R. C. Modelagem causal da astronomia antiga. 2014. 129f. Dissertação (Mestrado). Faculdade de Filosofia, Letras e Ciências Humanas. Departamento de Filosofia, Universidade de São Paulo, 2014.

Esta dissertação tem como objetivo apresentar a Modelagem Causal em História da Ciência (MCHC), e aplicá-la ao período da história da astronomia que vai dos primórdios ao século III AEC. Na primeira parte, exponho o método e discorro sobre algumas de suas implicações filosóficas - especialmente aquelas relacionadas com a noção de avanço - e historiográficas, ao mesmo tempo em que procuro inseri-lo no panorama da filosofia da ciência. Na segunda parte, que já é uma aplicação da MCHC, apresento uma pequena história da astronomia antiga, mostrando os principais avanços dos egípcios, babilônios e gregos, até Aristarco de Samos. Na última parte, utilizo os conceitos mobilizados na primeira parte e os avanços da segunda para apresentar o modelo causal da astronomia antiga e as conclusões dele derivadas.

Palavras-chave: astronomia antiga, modelos causais, causalidade, historiografia 


\begin{abstract}
FARIA, R. C. Causal modeling of ancient astronomy. 2014. 129 pgs. Thesis (Master Degree). Faculdade de Filosofia, Letras e Ciências Humanas. Departamento de Filosofia, Universidade de São Paulo, 2014.

This thesis aims at presenting the Causal Modeling of the History of Science (MCHC), and applying it to the period of the history of astronomy comprising its beginning until the 3rd century BCE. In the first part, the method is discussed and some of its philosophical and historiographical implications are analyzed - especially those related to the notion of advance. In the second part, an application of $\mathrm{MCHC}$, a short history of ancient, is presented, showing the main advances of the Egyptians, Babylonians, and Greeks, up to Aristarchus of Samos. In the final part, I use the concepts deployed in the first part and the advances discussed in the second part to present a causal model of ancient astronomy and the conclusions therefrom derived.
\end{abstract}

Keywords: ancient astronomy, causal models, causation, historiography 


\section{Sumário}

Introdução. 1

Capítulo 1. A Modelagem Causal em História da Ciência........................................... 3

1. Modelagem Causal em História da Ciência (MCHC).............................................. 3

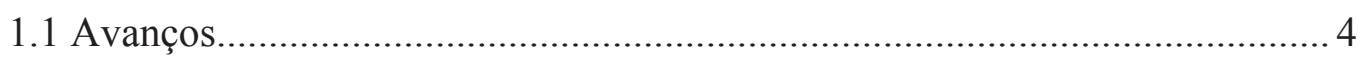

1.1.1 Avanços são unidades de conhecimento............................................. 6

1.1.2 Avanços são passados de cientista para cientista................................. 9

1.1.3 Os avanços abrangem uma ampla gama de práticas dos

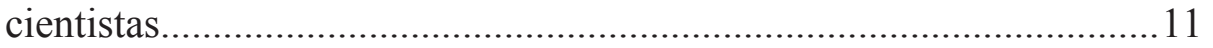

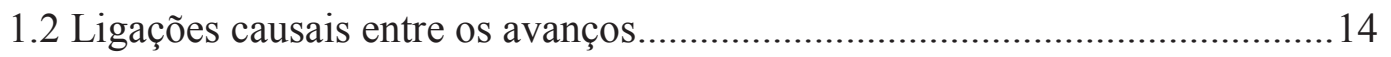

1.2.1 A causalidade na historiografia...................................................... 15

1.2.1.1 A historiografia whig e a MCHC.......................................... 21

1.2.2 Força causal dos avanços........................................................... 27

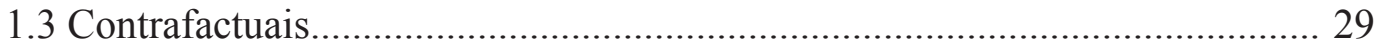

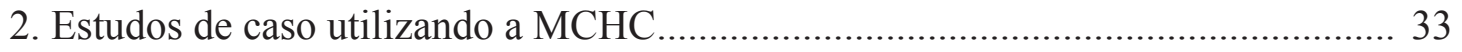

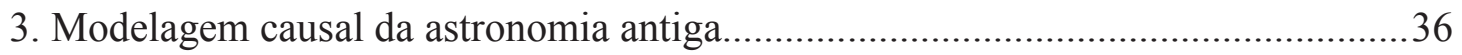

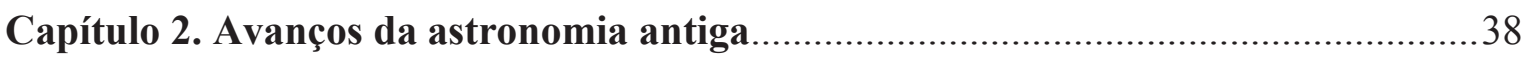

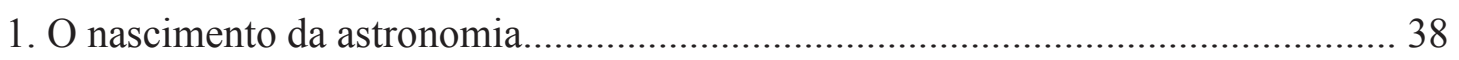

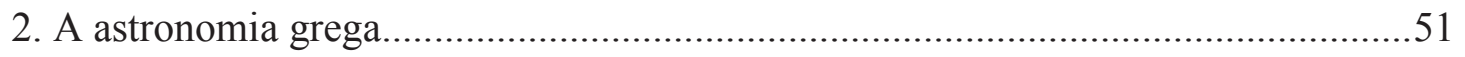

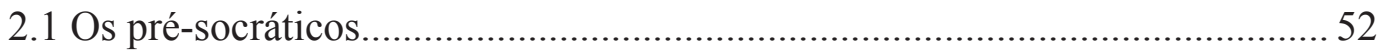

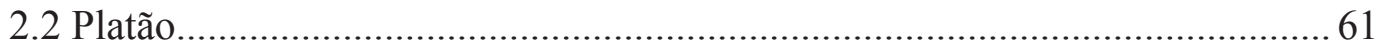

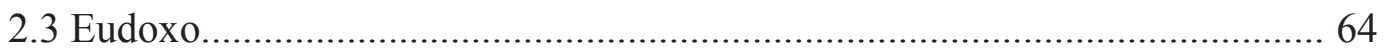

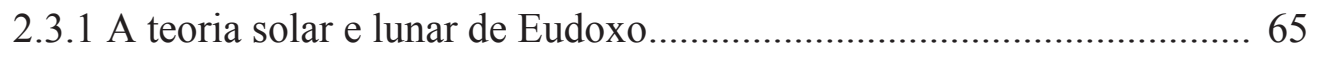

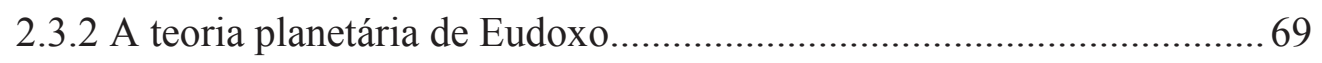

2.3.3 As modificações do modelo de Eudoxo por Cálipo.............................73

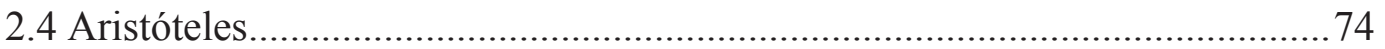

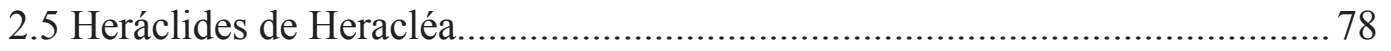

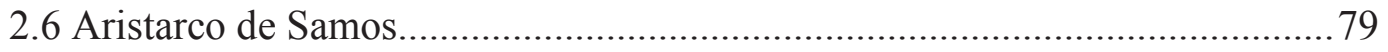

2.6.1 O cálculo de Aristarco dos tamanhos e distâncias do Sol e da Lua 


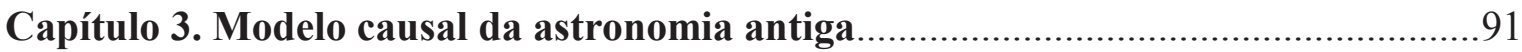

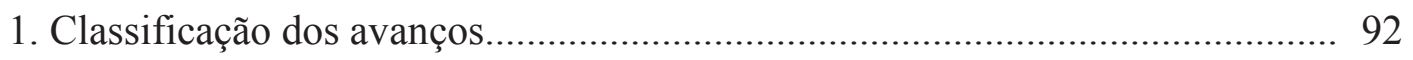

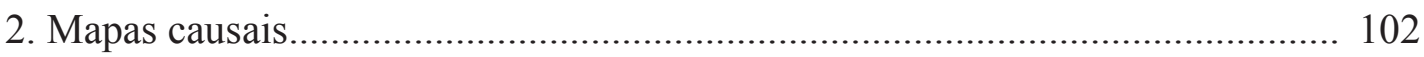

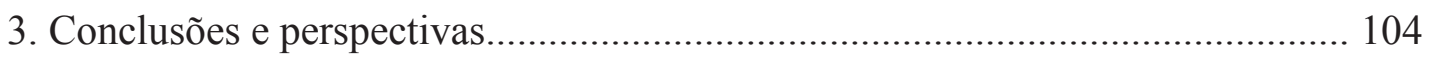

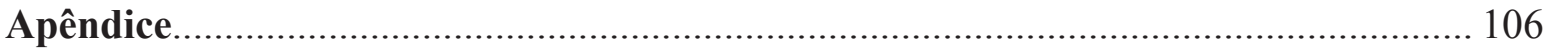

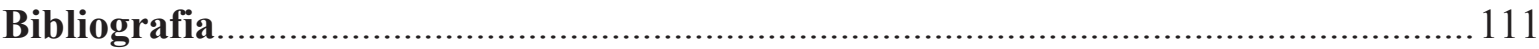




\section{Introdução}

O objetivo desta dissertação é utilizar uma abordagem filosófico-historiográfica chamada Modelagem Causal em História da Ciência (MCHC) na análise da astronomia produzida até o século III AEC no Egito, Babilônia e Grécia. Esse período de tempo é fértil em ideias e desenvolvimentos na astronomia. Dos primeiros olhares curiosos para os fenômenos celestes até o desenvolvimento da teoria heliocêntrica de Aristarco de Samos, é nesse intervalo temporal que são lançadas algumas das bases da ciência astronômica, que irão fundamentar a visão do homem sobre os céus, e sobre seu lugar no Universo, até o início da modernidade na Europa.

A MCHC é um método que pretende descrever a ciência e possibilitar intuições sobre como ela se desenvolve no tempo, e se baseia no estabelecimento de conexões causais entre avanços. Os avanços são as unidades a partir das quais são analisadas as mudanças na ciência. Coletados a partir de fontes primárias e secundárias do caso científico ou período da história da ciência estudado, os avanços são classificados em diversos tipos: teorias, observações, manifestações culturais, etc. Suas ligações causais podem ser representadas num mapa causal, que representa graficamente como um avanço ajuda a produzir outro. De acordo com o caso estudado, é possível postular histórias contrafactuais, caminhos alternativos a partir dos quais a ciência poderia ter sido produzida.

No primeiro capítulo, apresento a MCHC, destacando três aspectos da abordagem: a noção de avanço, a causalidade e os contrafactuais. Em relação ao primeiro aspecto, procuro apontar em que sentido um avanço é uma unidade de conhecimento, e quais são as vantagens do seu uso na análise da ciência. Essas unidades de conhecimento não são, entretanto, conceitos abstratos sem ligação com a maneira pela qual a ciência é produzida, mas pretendem espelhar a prática real da ciência, vale dizer, a maneira como os conhecimentos são passados de cientista para cientista. O reconhecimento do caráter social da ciência faz com que seja necessário mostrar como o conceito de avanço pode abranger uma ampla gama de práticas encontradas na ciência, de forma a tornar flexível e compreensiva sua utilização como instrumento de análise.

O segundo aspecto da MCHC que abordo no primeiro capítulo é a causalidade, já que o método pretende indicar a ligação causal entre os avanços. Trata-se de saber qual conceito de causalidade é o mais adequado para o uso com avanços tirados da história da ciência. Analiso dois tipos de causalidade: a que se baseia na regularidade, de David Hume, e a 
abordagem condicional de causalidade, de John Mackie. A escolha que faço pelo segundo tipo gera a questão de quais fatores são ou não relevantes num relato historiográfico, e, assim, de possíveis critérios de seleção do que deve ser incluído ou não na historiografia - ou de quais avanços devem ser escolhidos. Na história da ciência, os critérios utilizados dependerão do posicionamento do pesquisador em dois eixos: o papel causal de fatores intelectuais e não intelectuais, e a finalidade da pesquisa, isto é, em que medida o anacronismo é aceito. Com isso, passo a considerar aquelas características do anacronismo que a $\mathrm{MCHC}$ procura evitar e aponto para outras que me parecem inevitáveis.

$\mathrm{Na}$ última seção de apresentação da $\mathrm{MCHC}$, exponho a possibilidade das histórias contrafactuais, apontando para dois tipos de contrafactual: um que deriva do conceito de causalidade utilizado, e outro que leva em consideração as alternativas consideradas pelos contemporâneos da situação sob análise. Apresentada a MCHC, apresento alguns estudos já feitos com a abordagem.

O segundo capítulo consiste numa apresentação dos avanços da astronomia antiga, dos primórdios até o século III, apresentados em ordem cronológica e explicados, com a finalidade de serem analisados e incluídos no modelo causal do capítulo 3. Esse capítulo é uma pequena história da astronomia antiga até Aristarco, incluindo avanços egípcios, babilônios e gregos.

Por fim, o capítulo 3 contém o mapeamento causal e a análise dos avanços apresentados no capítulo 2. Esses avanços são classificados e incluídos em mapas causais, que mostram como se conectam entre si. Faço também algumas considerações sobre o modo de se praticar ciência que caracteriza a astronomia antiga.

Esta dissertação é uma apresentação, uma defesa e um exemplo da utilização da MCHC, ao mesmo tempo em que é um estudo da astronomia antiga. Espero, assim, mostrar a fertilidade da abordagem e auguro que outros estudos que a utilizem possam surgir. 


\section{Capítulo 1}

\section{A Modelagem Causal em História da Ciência}

Esta dissertação pretende aplicar uma abordagem filosófico-historiográfica chamada Modelagem Causal em História da Ciência (MCHC) à astronomia antiga, com foco nos desenvolvimentos babilônicos, gregos e helenísticos. Meu objetivo é criar uma fundamentação filosófica e historiográfica para a $\mathrm{MCHC}$, para, em seguida, aplicá-la à astronomia antiga. Assim, pretendo tanto mostrar uma forma nova de representar a história da astronomia, quanto fazer algumas considerações sobre o desenvolvimento dessa ciência na Antiguidade ${ }^{1}$.

Mas, o que é, afinal, a MCHC? Neste capítulo, apresentarei a MCHC e examinarei algumas questões historiográficas relativas a ela, como o uso da causalidade e dos contrafactuais. A seguir, darei alguns exemplos de estudos feitos com a MCHC e, por fim, darei mais detalhes sobre os objetivos da presente dissertação.

\section{Modelagem Causal em História da Ciência (MCHC)}

A MCHC é um método filosófico-historiográfico que pretende descrever a História da Ciência. "Filosófico" porque, partindo de certa concepção ontológica acerca dos "átomos" da ciência, as unidades a partir das quais o conhecimento é gerado e transmitido, procura analisar a dinâmica da ciência na história; "histórico" porque trabalha todo o tempo com a História da Ciência, que é o seu objeto.

A MCHC procura descrever a história da ciência através da ligação causal entre avanços $^{2}$. A partir disso, a abordagem pode utilizar contrafactuais para postular caminhos

\footnotetext{
${ }^{1}$ Minha intenção não é fazer um trabalho filológico com a utilização dos textos babilônicos e greco-romanos originais.

${ }^{2}$ Vale deixar claro desde já que a palavra "avanço" é usada na MCHC como um termo técnico, sem qualquer compromisso com uma visão progressista, racionalista e cumulativa de ciência. Tal visão teria dificuldades em assumir a importância de aspectos ditos "não racionais" no desenvolvimento da ciência, por exemplo, o papel da astrologia como fator motivador do aperfeiçoamento dos métodos de cálculo de posições dos planetas na astronomia grega do período anterior a Hiparco, dificuldade essa que a noção de avanço, tal como apresentarei, não tem.
} 
históricos alternativos. De fato, como veremos, o recurso aos contrafactuais já está embutido na própria noção de causa. Outro conceito da MCHC é o de força causal.

Os avanços são representados graficamente nos mapas causais, que mostram as suas relações causais através de "diagramas estruturais (grafos acíclicos direcionados ${ }^{3}$ ) cujos nodos representam variáveis (avanços) e cujas flechas (ligando os nodos) representam dependências causais entre as variáveis" (PESSOA JR., 2010a, p. 14). Quando as flechas apontam para o mesmo nodo, indicam uma disjunção de causas; quando unidas pelo símbolo "\&”, uma conjunção de causas. A representação gráfica dos avanços permite a visão sintética deles e de suas relações causa-efeito, permitindo a análise da estrutura causal do caso estudado. $\mathrm{Na}$ figura 1, abaixo, os avanços A e B causam, conjuntamente, o avanço C.

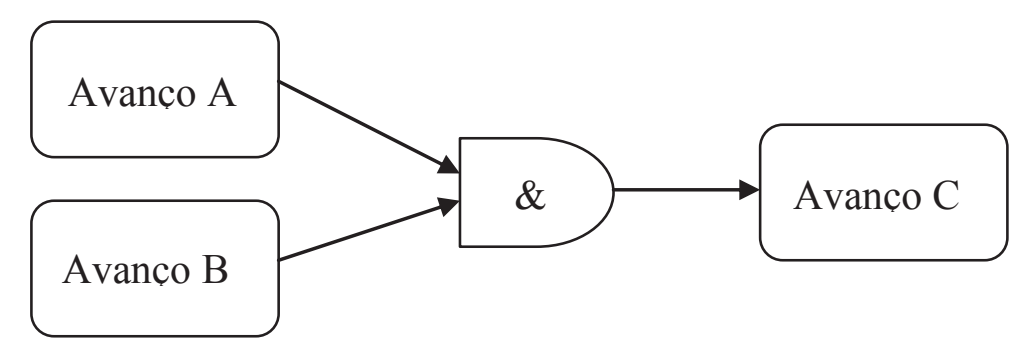

Figura 1. Modelo causal representando uma conjunção de causas.

\subsection{Avanços}

A MCHC faz ligações causais entre avanços. Avanços são

[...] as unidades que são passadas de cientista para cientista, são os elementos que são adicionados ao conjunto de ideias, dados, leis, informações, conhecimentos tácitos, etc., disponíveis para um certo cientista em uma época específica (PESSOA, 2000, p. 179).

Se partirmos dessa caracterização da noção de avanços, podemos notar alguns pontos importantes: os avanços (i) são unidades do conhecimento científico, (ii) são passados de cientista para cientista, (iii) abrangem uma ampla gama de práticas dos cientistas em um determinado período histórico.

\footnotetext{
3 "O gráfico deve ser acíclico - isto é, não há sequência conectada de flechas na mesma direção que entra e sai do mesmo vértice [nodo]" (Glymour, 2001, p. 25). Deve ser assim para que um avanço não seja causa de si mesmo.
} 
Alguns exemplos podem ser úteis para indicar a utilização da noção de avanço. No caso da astronomia antiga, tema da presente dissertação, a ideia da Terra no centro dos Cosmos é creditada por Aristóteles ao filósofo jônico Anaximandro, contemporâneo mais jovem de Tales de Mileto (Dreyer, 1953, p. 14). Para Anaximandro, a Terra estaria em equilíbrio no centro por não ter tendência a cair para nenhuma parte, já que está no meio. Se quisermos classificar esse avanço, podemos considerá-lo uma visão de mundo, já que não se baseia na observação, mas em concepções culturais e metafísicas.

Outro exemplo de avanço é a ideia da forma esférica da Terra, atribuída a Parmênides ou a Pitágoras ${ }^{4}$ (EvAns, 1998, p. 47). Até então, considerava-se a Terra como plana ou cilíndrica. Novamente, podemos considerar o avanço como uma visão de mundo por ser baseado primordialmente em razões de ordem metafísica, ainda que seja provável que os dois filósofos conhecessem os relatos dos navegadores da época sobre estrelas que se tornavam circumpolares quando eles iam para o norte (DREYER, 1953, p. 20, 37-38).

DREYER (ibidem, p. 31) afirma que a ordenação dos planetas, tal como seria usada por Platão e Aristóteles, foi feita por Anaxágoras, que os arranjou nesta ordem: Lua, Sol, Vênus, Mercúrio, Marte, Júpiter e Saturno ${ }^{5}$ (Lua e Sol eram considerados pelos gregos como planetas, no sentido etimológico grego da palavra, viajante). Como a existência dos sete planetas já era conhecida, o que Anaxágoras fez foi uma classificação teórica.

A ideia de um Universo formado por duas esferas (tal como Kuhn denomina a cosmologia que consiste na "Terra [...] suspensa estacionada no centro geométrico de uma esfera rotatória muito maior que carrega as estrelas" [KUHN, 1957, p. 27]) aparece - ou, ao menos, se consolida - em Platão como efeito das ideias anteriores. Anaximandro já assumia a existência de uma esfera externa à Terra, que, no entanto, não era considerada esférica; Pitágoras considerava que tanto essa esfera externa quanto a Terra fossem esféricas, mas em seu sistema a última não ocupava o centro ${ }^{6}$; Anaxágoras, que deu a ordem dos planetas, acreditava que a Terra era plana. Parmênides considerava que a Terra esférica estava no centro de uma esfera externa, mas adotava outra ordem para os planetas, posicionando o Sol acima das estrelas (algo que DREYER considera "um estranho erro" [1953, p. 21]). Assim, o

\footnotetext{
${ }^{4}$ A tradição clássica atribui o avanço ora a um, ora a outro desses filósofos. Teofrasto o atribui a Parmênides; Diógenes Laércio, a Pitágoras. Ver a seção 2.1 do capítulo 2.

${ }^{5}$ Ptolomeu adotará ordem Lua, Mercúrio, Vênus, Sol, Marte, Júpiter e Saturno, que é creditada aos pitagóricos (EVANS, 1998, p. 348).

${ }^{6}$ De acordo com a visão do pitagórico Filolau de Crotona. Não se sabe ao certo a opinião dos primeiros pitagóricos acerca da posição da Terra no Cosmos. Ver a seção 2.1 do capítulo 2.
} 
avanço que surge em Platão, o Universo de Duas Esferas, com a ordenação dos planetas dada por Anaxágoras, a Terra esférica e suspensa no centro do Cosmos, é um efeito dos avanços anteriores considerados como causas. Isso pode ser representado através do mapa causal abaixo:

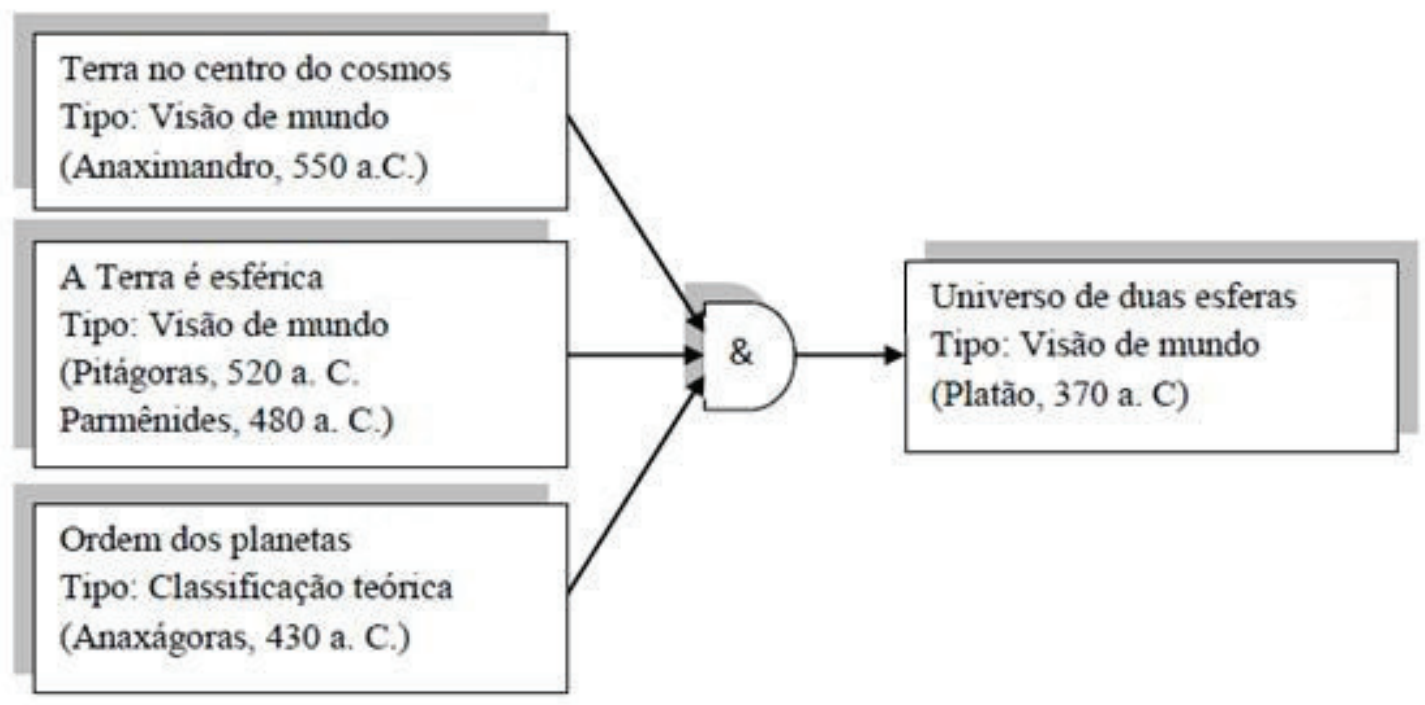

Figura 2. Exemplo de modelo causal, com as causas do avanço "Universo de duas esferas".

Passo agora a analisar cada um dos pontos da definição de avanço dada acima.

\subsubsection{Avanços são unidades de conhecimento}

Falar em unidades de conhecimento equivale a criar uma ontologia da ciência. Sem entrar em longas discussões, podemos assumir por ora que ciência é a atividade que os cientistas fazem. Mas, o que, afinal, fazem os cientistas? A resposta a essa questão parece simples: os cientistas observam a natureza, fazem experimentos, criam hipóteses, formulam teorias, etc. Mas, obviamente, a ciência não se reduz a um amontoado caótico de observações, experimentos, hipóteses e teorias: deve haver um método - o chamado método científico que dê coesão às várias atividades dos cientistas, de forma a gerar conhecimento que seja transmissível e criticável. Mas, além das atividades dos cientistas e do método, existem determinadas visões de mundo que guiam a pesquisa. Assim, por exemplo, a assunção da continuidade temporal das leis naturais é uma visão de mundo. Esses fatores - a lista pode ser 
sempre ampliada, com proveito para a $\mathrm{MCHC}$ - podem ser entendidos como vários tipos de avanços, que são os blocos constituintes do fazer científico. Abandonando agora a assunção que fizemos a respeito da natureza da ciência, e seja qual for a posição que se tenha a respeito daquilo que constitui a sua especificidade (ou a sua não especificidade), sempre se pode usar a noção de avanço como a unidade básica na metaciência. A noção de avanço é puramente formal; o elemento material, histórico e real advém da pesquisa histórica e irá depender da concepção do historiador ou filósofo acerca dos elementos atuantes na produção da ciência. Por isso, os avanços são escolhidos através do exame de fontes primárias e secundárias. Como os avanços são unidades formais, eles podem abranger vários tipos de práticas científicas. A classificação desses avanços depende do período histórico sob investigação, com determinados tipos de avanço aparecendo mais ou menos em cada época. Veremos mais adiante sobre a relação entre os avanços e as práticas científicas tais como se encontram na historiografia.

O conceito de avanço pode ser útil na análise de como os vários aspectos da ciência se relacionam, tanto no nível normativo da filosofia quanto no nível descritivo-interpretativo da história da ciência. A filosofia da ciência pode avaliar a afirmação de que um avanço de tipo experimental sempre se segue a um avanço de tipo teórico, e a história da ciência pode utilizar o conceito como uma espécie de guia para a atenção do historiador. William Whewell tentou algo semelhante a isso ao usar a história da ciência como fonte para a descoberta de uma lógica da ciência. A intenção de Whewell era a de criar uma filosofia da ciência a partir da história, e com isso ensinar os cientistas de sua época sobre formas melhores de se obter conhecimento científico. De fato, ele afirma que "deduzir essas lições a partir da história passada do conhecimento humano foi a intenção que deu origem à presente obra [a História das Ciências Indutivas]" (WheWell, 1857, p. 4). Ainda que a obra de Whewell possa gerar discordância em alguns aspectos (a história da ciência como fonte do método científico, o seu platonismo que faz com que as leis da natureza sejam derivadas das Ideias, etc.), a questão da possibilidade de se inferir a estrutura da ciência a partir de sua história é válida e ainda está aberta $^{7}$. Se a MCHC será capaz de fornecer uma teoria ampla sobre a estrutura da ciência (ou sobre a inexistência de uma estrutura única) é algo que só se poderá saber após uma ampla gama de estudos de caso.

Outra vantagem do uso do conceito de avanço refere-se à possibilidade do teste das teorias da mudança científica da chamada "escola histórica" (Thomas Kuhn, Imre Lakatos,

\footnotetext{
${ }^{7}$ Sobre isso, ver HALL (1970) e MAUSKopf \& SCHMALTZ (2012).
} 
Paul Feyerabend, Stephen Toulmin, Larry Laudan, etc.,). A filosofia da ciência da primeira metade do século XX foi dominada pela visão positivista-lógica, segundo a qual a ciência é diferente de outras atividades humanas devido ao método próprio (o método científico); é idealmente livre de valores políticos, morais e religiosos; é cumulativa em sua base empírica (que seria mais fundamental do que as elaborações teóricas); e a avaliação das teorias se dá através da simples comparação entre elas e os dados - comparação esta permitida e facilitada pela distinção entre enunciados teóricos e enunciados observacionais.

Essa visão da ciência começou a ser questionada a partir da metade do século. Algumas objeções eram de caráter filosófico: problemas em se trabalhar a lógica da confirmação, dificuldades em relação à distinção entre observação e teoria, e ambiguidades no teste de afirmações científicas isoladas. Outras objeções eram de caráter histórico: a história da ciência não autorizava o retrato positivista-lógico que dela se fazia (LAUDAN et al., 1993, p. 4). Então, ou a ciência, tal como praticada por séculos, estava errada, ou a filosofia que procurava entender essa ciência não o fazia muito bem.

É nesse contexto que surgem várias filosofias que procuram resgatar a história da ciência, focando-se, sobretudo, em períodos históricos de mudança científica. Os autores da “escola histórica" publicam textos em que procuram criar uma alternativa à visão positivistalógica da ciência, e para isso se baseiam na história. Uma característica comum desses autores é "a convicção de que qualquer teoria da mudança científica precisa se acomodar ao impressionante corpo de evidência sobre o rumo da ciência reunido pelos historiadores" (ibidem, p.5).

Porém, essas teorias da mudança científica não foram testadas sistematicamente contra o registro histórico. Como apontam LAUDAN et al.

[...] nenhuma dessas teorias "pós-positivistas" foi testada de uma maneira que não fosse a mais perfunctória e superficial. Nada semelhante aos padrões de teste que esses próprios autores sustentam dentro da ciência foi alguma vez satisfeito por qualquer uma de suas teorias sobre a ciência (ibidem, p. 2).

O conceito de avanço, entendido como a unidade básica de análise da ciência, pode facilitar a comparação e avaliação das várias teses propostas pelos filósofos da ciência da escola histórica, utilizando a MCHC. Convém notar, entretanto, que a relação entre história e filosofia da ciência não é unívoca, no sentido de que os filósofos da ciência devam sempre se curvar ao que dizem os historiadores. Isso seria assumir tanto que os historiadores são agentes neutros, capazes de produzir relatos imparciais e que contêm toda a verdade sobre a ciência, 
quanto assumir que os julgamentos dos cientistas sobre a ciência estão sempre corretos. A avaliação das teses filosóficas sobre as mudanças científicas e das motivações dos historiadores só pode ser feita dentro de uma metodologia em que filosofia e história atuem conjuntamente ${ }^{8}$.

Essa comparação e avaliação de teorias filosóficas sobre a ciência pode ser feita, em principio, a partir de estudos de caso utilizando a MCHC. Com a modelagem causal de um ou mais períodos pronta, poder-se-ia "traduzir" as teses dos vários filósofos para a linguagem dos avanços causalmente ligados da MCHC. De fato, LAUDAN et al. (1993) e DonOvAn et al. (1988) estabeleceram um programa de pesquisa que consiste em "testar" algumas das filosofias da ciência. A MCHC pode ser útil nessa linha de pesquisas ao proporcionar uma base comum para a efetuação de testes entre vários estudos de caso. Pretendo tratar mais profundamente desse tema em outra ocasião.

\subsubsection{Avanços são passados de cientista para cientista}

O fato de que os avanços são passados de cientista para cientista indica a natureza social da prática científica. A ciência é uma atividade essencialmente colaborativa, em que um cientista constrói sua pesquisa sobre os resultados da pesquisa de outros cientistas, usa instrumentos criados por outras pessoas, e procura divulgar os seus resultados para o escrutínio coletivo. Já Ptolomeu reconhece isso no início do Almagesto, quando diz que

[...] assim também nós tentamos aumentar continuamente nosso amor pela disciplina das coisas que são sempre as mesmas [...] aprendendo o que já foi descoberto em tais ciências por aqueles que realmente se aplicaram a elas, e também fazendo pequenas contribuições originais (Ptolomeu, 1984, p. 37).

O reconhecimento do caráter social da prática da ciência pode chegar até a opinião de que a própria ciência é totalmente determinada por fatores sociais. Essa é a abordagem da sociologia do conhecimento do chamado Programa Forte de David Bloor e outros (BARNES, BLOOR \& HENRY, 1996).

\footnotetext{
${ }^{8}$ Para Hasok Chang, existem três modos de interação entre história e filosofia da ciência: (i) a história como fornecedora do próprio objeto dos filósofos, (ii) a filosofia como criadora da estrutura conceitual usada pelos historiadores, e (iii) a interação crítica e conjunta de história e filosofia da ciência (CHANG, 2012, p. 123). A partir disso, Chang propõe o estudo conjunto da história e da filosofia da ciência, através do que ele chama de "ciência complementar" (ibidem, p. 235).
} 
Existem dois modelos que buscam entender como se dá a interação social dos cientistas e o modo com que essa interação afeta o conhecimento científico: (i) o modelo da formalização, e (ii) o modelo da expertise (SISMONDO, 2010, p. 143-144). No primeiro modelo, os conhecimentos científicos são passados de cientista para cientista dentro de uma estrutura. Essa estrutura pode se referir tanto às normas de conduta ética dos cientistas e ao fato de que "o objetivo institucional da ciência é a extensão do conhecimento certificado" (Merton, 1973, p. 270), quanto a uma explicação de ciência baseada na translação regrada entre os vários níveis de conhecimento, desde a descoberta pessoal de alguma regularidade na natureza até a criação de uma teoria abrangente. Enquanto a primeira interpretação do modelo da formalização foca-se principalmente nos valores morais que, sendo seguidos universalmente pelos cientistas, gerariam o sucesso da ciência, a segunda preocupa-se em mostrar que esse sucesso deve-se sobretudo à criação de redes de conhecimento, redes essas que irão determinar o próprio método e a conduta científica. Assim, Bruno Latour, um dos proponentes dessa segunda interpretação, diz que

A história da tecnociência é, em grande parte, a história dos recursos espalhados ao longo das redes para acelerar a mobilidade, a fidedignidade, a combinação e a coesão dos traçados que possibilitam a ação à distância (LATOUR, 1998, p. 424).

O modelo da expertise ou conhecimento tácito é aquele que advoga que os cientistas transmitem conhecimento, muitas vezes não formalizável, entre si e para seus alunos. Esse modelo aparece com Michael Polanyi, que afirma que o conhecimento tácito está presente quando alguém executa tarefas complexas regradas sem ter o conhecimento explícito ou consciente dessas regras. Para Polanyi, o conhecimento tácito atua também na ciência, de modo que

um cientista pode aceitar [...] a mais inadequada e enganosa formulação dos seus próprios princípios científicos sem sequer compreender o que está sendo dito, porque ele automaticamente a suplementa com seu conhecimento tácito do que a ciência realmente é [...] (POLANYI, 1962, p.179).

Boa parte da motivação desse modelo é o reconhecimento das dificuldades que o modelo da formalização apresenta: ambas as versões deste último apresentam regras que devem ser interpretadas. Em situações de grande complexidade, ambiguidade, novidade ou instabilidade, "regras formais não podem substituir com sucesso a expertise" (SISMONDO, 
2010, p. 143). O problema do modelo da expertise é aquele do conteúdo da transmissão: o que cientistas transmitem entre si? Esse é um problema que o modelo da formalização não tem, já que as interações entre os cientistas são guiadas por normas éticas e metodológicas.

Seja qual for o modelo adotado, a noção de avanço se mostra útil. No caso do modelo da expertise, os avanços seriam o conhecimento tácito transmitido entre os cientistas; no caso do modelo da formalização, os vários avanços podem mostrar tanto o modo como a estrutura institucional da ciência se manifesta, quanto as regras de translação entre os diversos conhecimentos - pode-se mostrar, por exemplo, como vários avanços de tipo observacionais “desembocam" em avanços teóricos. Em ambos os casos, portanto, o conceito de avanço pode ser usado para descrever o que é passado de um cientista a outro.

\subsubsection{Os avanços abrangem uma ampla gama de práticas dos cientistas}

Vimos que os avanços são unidades de conhecimento passadas de cientista para cientista, e que o elemento material advém do período histórico cuja ciência se estuda. Isso significa que a classificação dos avanços irá depender de como a ciência era praticada em determinada época, com alguns tipos de avanço sendo mais ou menos frequentes.

Num artigo sobre o surgimento da Física Quântica, Osvaldo Pessoa Jr. divide os avanços em dez classes: técnica experimental, dados experimentais, desenvolvimento da teoria, trabalho teórico, conceitos \& definições, leis \& fatos, comparação dados-teoria, explicações, problemas \& críticas e, por fim, motivações \& valores (PESSOA JR., 2000, p. 182). Já para a astronomia do período anterior à Hiparco, os avanços de tipo cultural, metodológico e de teorias rudimentares parecem, a princípio, ser a maioria, enquanto a partir dele outros tipos de avanço começam a aparecer, pois "enquanto seus predecessores se contentaram com explicação física geral, ele [Hiparco] insistiu em precisão" (EVANS, 1998, p. 213). Logo, os tipos de avanços que aparecem com maior frequência dependerão do período histórico estudado. Para o presente trabalho, parto da classificação proposta por Pessoa Jr, fazendo alterações onde necessárias ${ }^{9}$.

A alteração na frequência do aparecimento de certos tipos de avanços, segundo a época estudada, indica que as práticas dos cientistas são variáveis na história. Podemos

\footnotetext{
${ }^{9}$ Talvez a própria tipologia dos avanços possa mudar de uma época para outra. No entanto, a classificação acima, com alguns ajustes, me parece bastante abrangente para incluir avanços de boa parte da história da ciência.
} 
relacionar ciência e prática em dois sentidos: (i) a ciência enquanto prática macro-social, uma atividade realizada e reconhecida coletivamente, e (ii) as micro-práticas dos cientistas nos laboratórios e locais de pesquisa.

O primeiro sentido reconhece a ciência como algo mais do que a criação de teorias, levando em conta aspectos "não racionais" como a cultura, a economia e os valores. Essa abordagem foi salientada especialmente por Thomas Kuhn, que através do conceito de "matriz disciplinar" procura abranger a "posse comum aos praticantes de uma disciplina particular; 'matriz' porque é composta de elementos ordenados de várias espécies" (KUHN, 2001, p. 226). Peter Galison advoga que as práticas científicas estão longe de serem monolíticas, e se dispersam em várias sub-culturas (GALISON, 1995, p. 23), e certa flexibilidade interpretativa torna-se necessária para o estudo do que os cientistas fazem e de como se relacionam entre si e com a sociedade.

O segundo sentido da relação ciência-prática é aquele dos estudos etnográficos em laboratórios, como, por exemplo, o de LATOUR \& WoOLGAR (1997). Esses estudos tendem a concluir que os resultados científicos são dependentes das interações locais e pessoais entre os cientistas. Essa abordagem é praticamente inviável para estudos da ciência de épocas passadas, como é o caso do presente trabalho.

O foco na prática científica pode ser entendido também dentro da discussão sobre a distinção entre o contexto da descoberta e o contexto da justificação, feita por Hans REICHENBACH (1959) ${ }^{10}$. O contexto da descoberta diz respeito ao modo como as teorias são criadas, levando em conta as várias práticas que o cientista realizou até chegar à sua formulação. Já o contexto da justificação é aquele dos procedimentos metodológicos através dos quais uma teoria é avaliada. Para Reichenbach, apenas o segundo é o domínio próprio da filosofia, enquanto o primeiro é irrelevante para a criação de uma teoria da ciência. Essa distinção é destacada por Karl Popper em seu Logic der Forschung (Lógica da Investigação Científica). Para Popper, os problemas relacionados ao contexto da descoberta são objeto da psicologia empírica e, dessa forma, "a etapa inicial, o ato de conceber ou inventar uma teoria, não me parece exigir uma análise nem ser suscetível dela” (POPPER, 1975, p. 266).

\footnotetext{
${ }^{10}$ A distinção entre, de um lado, os processos de descoberta e formulação de leis e teorias e, de outro, os critérios de aceitabilidade das teorias (portanto, entre um contexto da descoberta e um contexto da justificação) aparece já em John Herschel, em seu A Preliminary Discourse on the Study of Natural Philosophy, de 1831. No entanto, diversamente de Reichenbach, Herschel não considera que apenas o contexto da justificação é passível de estudo filosófico, e analisa também os "processos para a descoberta daquelas leis elementares em que as teorias de alto nível estão fundamentadas" (HERSCHEL, 1831, p. 199).
} 
Nesse sentido, tanto Reichenbach quanto Popper desenvolveram suas teorias filosóficas como contribuições normativas, e não descritivas, do processo científico real, tal como ocorreu na história. Com a revalorização da história da ciência a partir dos anos 50, autores como Kuhn e Paul Feyerabend passam a desconsiderar a distinção entre os dois contextos. Para Kuhn, "tais noções não se adaptavam às exigências do empreendimento apresentado pelo estudo histórico" (KUHN, 2001, p, 10). Também Feyerabend, motivado pelo estudo histórico da ciência de Galileu, diz que

Os resultados até agora conseguidos trazem em seu bojo a sugestão de abolir a distinção entre contexto da descoberta e contexto da justificação e de pôr de parte a distinção correlata entre termos observacionais e termos teoréticos. Nenhuma dessas distinções tem papel a desempenhar na prática científica. Tentativas de dar-lhes força trariam consequências desastrosas (FEYERABEND, 1977, p. 257).

E quais seriam essas consequências? Augustine Brannigan afirma que a distinção entre os contextos de descoberta e justificação era uma resposta de Reichenbach e Popper à sociologia do conhecimento de Karl Mannheim (BRANNIGAN, 1984, p. 68). Essa sociologia indicava que o conhecimento é dependente do contexto socioeconômico em que surge, o que implica o relativismo. Para evitar essa "contaminação" social do conhecimento, o contexto da justificação surge como o antídoto correto: esse contexto é aquele em que a veracidade da uma ideia pode ser aferida sem qualquer menção à sua origem. O contexto da descoberta torna-se, então, justamente onde surgem as ideias - desde que se considere que o surgimento das ideias é uma questão puramente psicológica, e não socioeconômica ou política ${ }^{11}$. Assim, a negação da importância do modo como a ciência se faz e a atribuição à psicologia do seu estudo fazem com que se perca de vista aspectos importantes que podem influenciar o surgimento de vários aspectos da ciência, incluindo as teorias.

Dentro da MCHC, a valorização da prática dos cientistas é, dessa forma, uma tentativa de levar em conta quaisquer fatores que influenciem o conhecimento e o trabalho dos cientistas. Por isso, ela pode resgatar os aspectos que Reichenbach e Popper consideravam supérfluos para a filosofia da ciência. Não é à toa que autores como Norwood HANSON (1958) e Richard BlaCKWELl (1969) falaram em uma "lógica da descoberta", que é a formulação das etapas que levam até uma descoberta científica. Se levarmos em conta outros aspectos da

\footnotetext{
${ }^{11}$ A atribuição do estudo do contexto da descoberta à psicologia indica que qualquer fator social ou político reduz-se, em última instância, a ela.
} 
ciência que não apenas as descobertas, mas também a criação de hipóteses, experimentos, observações, etc., e se tentarmos mostrar as etapas necessárias e suficientes para essa criação, podemos utilizar a MCHC. O objetivo é mostrar como os vários avanços surgem a partir de outros, de maneira descritiva. Dessa forma, a MCHC é naturalizada no sentido de Quine:

[Minha] posição é naturalística; eu vejo a filosofia não como uma propedêutica a priori ou uma fundamentação para a ciência, mas como contínua com a ciência. [...] Não há ponto de vantagem externo, não há filosofia primeira (QUINE, 1969, p. 11).

A insistência nas práticas dos cientistas na criação de hipóteses, experimentos e teorias é validada também pela possibilidade de se reconhecer as ligações, continuidades e mudanças entre as ideias científicas. Em um estudo sobre o surgimento da "lei dos quadrados" de Galileu, W. C. Humphreys volta-se para as anotações e trabalhos de juventude do italiano a fim de mostrar como ele chegou ao resultado. Para Humphreys, essa abordagem pode mostrar que há "uma profunda continuidade" (HuMPHREYs, 1967, p. 225) entre as primeiras e as últimas pesquisas de Galileu e entre seu pensamento e o de autores de períodos anteriores. Ao estudar as práticas dos cientistas e os caminhos que os levaram até os avanços, podemos compreender os vários nexos entre essas práticas.

\subsection{Ligações causais entre os avanços}

Os avanços são unidades de conhecimento passadas de cientista para cientista. Essa passagem pode ser entendida através de uma relação causal: um avanço (ou um grupo de avanços) provoca o surgimento de outro, ou seja, quando um cientista faz uma observação, descobre alguma regularidade, faz algum experimento, cria uma teoria, etc., ele irá influenciar tanto o seu próprio trabalho quanto o de outros cientistas, produzindo novos avanços.

Há duas razões para o uso do conceito de causalidade na MCHC: em primeiro lugar, esse uso é uma escolha metodológica coerente com a pretensão da MCHC de ser "uma contribuição para a "ciência da ciência"” (PESSOA JR., 2010a, p. 1), e por isso, tal como qualquer outra ciência, ela utiliza a noção de causa. Em segundo lugar, o uso da ideia de causa é bastante comum nas narrativas historiográficas, que são feitas de "uma miríade de ligações causais que conectam descrições de processos ou eventos históricos" (TUCKER, 2009, p. 98). Como a MCHC é um método filosófico-historiográfico que trabalha com a História da Ciência, o uso da causalidade também aparece nela. 
Há que se notar, entretanto, que a noção de causalidade pode ser caracterizada de várias formas. No caso da MCHC, essa caracterização deve ser baseada no uso do conceito na historiografia. No que se segue, tentarei mostrar qual é o conceito de causalidade que a MCHC utiliza.

\subsubsection{A causalidade na historiografia}

Embora a causalidade apareça em muitos trabalhos historiográficos, seu uso não é unanimidade entre os historiadores. Aviezer TUCKER (2009) reconhece duas atitudes em relação a ela: de um lado estão os excepcionalistas; de outro, os unificacionistas. Os primeiros argumentam a favor da excepcionalidade do uso da causalidade na história, enquanto os segundos defendem a identidade desse conceito em todas as ciências. Caracterizemos essas duas abordagens.

A afirmação de que a história e as demais ciências humanas são radicalmente diferentes das ciências da natureza por causa do seu objeto, o homem, é o principal ponto daqueles que defendem a especificidade (ou, no caso dos mais radicais, a extirpação) da causalidade da historiografia, os excepcionalistas. Para eles, existem causas em ação na história, mas essas são de um tipo diferente daquele que ocorre nas ciências naturais. Uma das correntes dessa abordagem afirma que a causalidade na história é do tipo teleológica, em que os eventos acontecem para se chegar a determinado fim. Essa é, por exemplo, a ideia de Hegel, para o qual a história humana é um desenvolvimento que "busca um resultado de conteúdo inequívoco. Esta finalidade [...] é o espírito em sua essência, o conceito de liberdade" (HEGEL, 2001, p. 107).

Outra abordagem excepcionalista afirma que as causas na história podem ser melhor identificadas como razões pessoais para que os atores históricos façam ou deixem de fazer algo. Como o historiador pode reconhecer essas razões pessoais, Robin Collingwood afirma que a história é "a reencenação do pensamento passado, na mente do próprio historiador" (COLlingwoOd, 1980, p. 215).

A posição excepcionalista extrema é aquela que propõe a exclusão da causalidade da historiografia. Para os defensores desse ponto de vista, falar em causalidade histórica é o mesmo que fechar o ser humano na prisão de um determinismo estrito que nega a liberdade do homem e torna os eventos históricos tão passíveis de predição quanto os fenômenos naturais. Ainda que o mundo - inclusive a história - possa ser determinista, essa posição ataca 
especificamente a ideia do uso de leis gerais para a explicação de eventos do passado, tal como Carl Hempel (1942) propunha. Seu modelo nomológico-dedutivo dizia que a explicação de qualquer evento se dava através de dois conjuntos de premissas - as condições antecedentes e as leis gerais - dos quais se deduz o evento. Como as leis gerais exprimiriam relações causais, a negação da possibilidade dessas leis gerais transforma-se, em última instância, em negação da aplicação do conceito de causalidade na historiografia.

Já os unificacionistas afirmam a unidade do conceito de causalidade em todas as ciências e na historiografia. Para eles, o mesmo tipo de análise causal feita, por exemplo, na física, pode ser aplicado à história. Existem duas visões básicas de causalidade dentro dessa abordagem: a de David Hume e a chamada concepção condicional.

Já foi dito que Hume queria ser o "Newton das ciências morais" 12" (GARRET, 2008, p. 55), em reconhecimento da importância que a obra do cientista tem para o filósofo escocês. De fato, um dos temas preferidos de Hume era o da explicação de como a ciência opera, partindo do princípio de que as ideias são derivadas da experiência. Nesse campo de problemas, a causalidade era um de seus alvos preferidos, principalmente em suas tentativas de eliminar os traços metafísicos do conceito e de reduzi-lo à regularidade: Hume não considera que a causa tenha alguma força oculta que produza o efeito; antes, nosso estabelecimento da conexão causa-efeito é fruto do hábito. Se vejo uma chama e infiro, após muitas experiências, que haverá calor nela e ao seu redor, passo a chamar a primeira de causa e o segundo de efeito. Nada me garante que isso será assim amanhã, dado que a ideia de uma necessidade dessa relação é fruto apenas de uma conjunção constante.

Com base nisso, Hume define a causa como "um objeto, seguido de outro, tal que todos os objetos semelhantes ao primeiro serão seguidos por objetos semelhantes ao segundo" (HuME, 2009, p. 115). Detalhando um pouco mais, a causalidade é uma relação regular entre duas coisas ou eventos em que: (i) as causas precedem os efeitos, (ii) os efeitos são próximos às causas, e (iii) causas iguais produzem efeitos iguais.

Esta mesma concepção de causalidade se aplicaria à história. Logo de início, entretanto, impõe-se uma consideração: a história não parece apresentar casos de conjunções constantes de causa e efeito, e os escritos historiográficos geralmente atribuem um conjunto de causas, em vez de uma causa simples, para um determinado evento. Os acontecimentos da

\footnotetext{
12 Para Hume, as ciências morais são "o estudo do que hoje nós entendemos como história, economia e teoria política, lógica, epistemologia e metafísica, estética, e ética” (BELL, 2009, p. 148).
} 
história parecem ser singulares, relacionados à época e às várias condições em que ocorrem. Parece, então, que a causalidade histórica é diferente da causalidade das ciências da natureza.

Hume evita esse problema ao apelar para a noção de "natureza humana". Esse é o fator que permite a compreensão da causalidade história como regularidade - e, portanto, como igual à causalidade das ciências naturais. $\mathrm{O}$ escocês procura uma teoria geral da natureza humana, que lhe permita entender como os homens pensam, sentem e agem, e é a universalidade dessa natureza que garantirá o mesmo tipo de fator causal em todos os acontecimentos da história. De fato, a natureza humana é bastante utilizada pelos autores das "ciências do homem" do século XVIII para explicar os diferentes costumes dos povos e sua história $^{13}$. Um exemplo do uso da noção de natureza humana na historiografia pode ser encontrado num trecho do próprio Hume, na sua História da Inglaterra, acerca das campanhas militares de Eduardo III:

E realmente, a partir do desafortunado estado da natureza humana, irá acontecer comumente que um soberano de gênio [sovereign of genius], como Eduardo, que usualmente tem facilidade no seu governo doméstico, irá se voltar para os empreendimentos militares, onde unicamente pode encontrar oposição e onde pode exercitar plenamente sua indústria [industry] e capacidade (HuME, 2004, p. 540).

Caracterizada a uniformidade causal na história e nas ciências naturais, surge outra questão: como diferenciar uma conjunção causal de eventos de uma conjunção não causal ${ }^{14}$ ? Há casos em que dois fenômenos aparecem conjugados sem que ambos sejam um a causa do outro, como, por exemplo, o dia e a noite. Como, então, diferenciar os casos em que um objeto/evento é causa de outro dos casos em que dois objetos/eventos, embora próximos, são efeitos de um terceiro objeto/evento?

A resposta está numa concepção contrafactual da causalidade. A noção contrafactual da causalidade estabelece uma relação entre os objetos/eventos tal que "se o primeiro não existisse, o segundo jamais existiria” (Hume, 2009, p. 115). Com essa concepção é possível distinguir, pelo menos em teoria, os casos de causalidade dos casos de simples conjunção.

\footnotetext{
13 “Os pensadores newtonianos do século XVIII já reconheciam especificidades no estudo do homem, como, por exemplo, a impossibilidade de realizar experimentos controlados ou da verificação repetida de resultados. Contudo, parecia-lhes experiência suficiente a observação dos homens em sociedade, somada aos relatos da história e dos povos distantes, sobre a qual ancoravam generalizações raciocinadas sobre o comportamento humano, os costumes, as instituições e as leis. Dessa forma, tanto os newtonianos da física como aqueles da cultura, partilhavam um mesmo espírito científico experimental" (ALBIERI, 2010, p. 291).

${ }^{14}$ Essa é a falácia lógica conhecida como post hoc, propter hoc.
} 
No entanto, essa capacidade de distinção entre os casos acaba por não ser relevante para a história tal como Hume a concebe, e isso por causa do fator causal atuante, a natureza humana. Já que essa é o grande fator causal na história, faria pouco sentido tratar de outras causas e condições - ou, no máximo, essas outras causas e condições ocupariam um lugar secundário na historiografia. Aplicar o critério contrafactual a uma abordagem que reconhece apenas - ou principalmente - a natureza humana como causa teria como resultado uma interpretação subjetivista e personalista da história, em que os eventos ocorrem apenas por causa de vícios e virtudes de um ou outro ator histórico. Contra isso, autores como John Stuart Mill notaram que a singularidade causal é algo "raro, se é que isso acontece alguma vez" (MILL, 1974, p. 181), e é por isso que as diversas condições presentes na produção do efeito devem ser consideradas na análise causal.

Exatamente para levar em conta as diversas condições que existem num dado período e que levam a um determinado evento, surge a concepção condicional da causalidade. Em geral, quando estuda um período ou evento, o historiador analisa um conjunto de condições e procura, entre essas, quais foram as mais importantes para o desenvolvimento das características do período ou do evento - essas últimas serão as causas. Um exemplo dessa forma de se escrever história aparece num trecho de The History \& Practice of Ancient Astronomy em que o autor James Evans menciona duas causas para o aperfeiçoamento quantitativo da astronomia helenística a partir do século II AEC: em primeiro lugar, o desenvolvimento da trigonometria, e, em segundo lugar, a recepção dos registros astronômicos babilônicos. Evans reconhece, porém, que tais causas só podem atuar dentro de um amplo conjunto de condições, que formam o

[...] cenário político, militar e cultural. A astronomia grega já tinha maturado ao ponto em que podia beneficiar-se grandemente do exemplo babilônico. Além disso, agora o contato era fácil, pois a Mesopotâmia, assim como o Egito, era governada por uma dinastia macedônica falante de grego. Em todo o Oriente Médio, os gregos eram colocados em contato com outros povos. Costumava ser comum falar do "milagre grego", como se os gregos tivessem inventado a ciência de uma só vez, junto com a história, a poesia e a democracia. Embora o feito grego em astronomia e matemática tenha sido realmente marcante, não podemos mais considerá-lo como se não tivesse raízes em outras culturas (EVANS, 1998, p. 23).

Uma sistematização da questão das causas e condições foi proposta por John Mackie em seu artigo "Causes and conditions" (1965). Mackie define a causa como "[...] uma parte insuficiente [Insufficient], mas necessária [Necessary], de uma condição que por si mesma não é necessária [Unnecessary], mas suficiente [Sufficient], para o resultado" (MACKIE, 1965, 
p. 245). As iniciais das palavras inglesas em itálico formam o acrônimo INUS. Mackie exemplifica o uso do esquema INUS através do caso de um incêndio cuja causa é procurada. Supondo que os peritos cheguem à conclusão de que a causa do incêndio foi um curtocircuito, qual é o status dessa causa? Por um lado, o curto-circuito não é uma condição necessária para a produção do incêndio, já que este poderia ser causado por outros eventos; por outro lado, o curto-circuito não é uma condição suficiente para que ocorra um incêndio: é preciso que haja materiais inflamáveis por perto, e que não haja equipamento de segurança que apague o fogo logo no início. Portanto, não se pode dizer que o curto-circuito causou o incêndio, a não ser que se considere a existência de um conjunto de condições dentro das quais ele se torna um fator atuante. Dentro desse conjunto, o curto-circuito é um elemento necessário, pois, mantido todo o resto igual, sem ele não haveria o incêndio; é também insuficiente, já que são necessários outros elementos (presença de materiais inflamáveis, oxigênio, falta de equipamentos de segurança, etc.) para que se produza o efeito. O conjunto das condições é, por sua vez, suficiente para a produção do efeito: se tivermos material inflamável, oxigênio, curtos-circuitos, etc., teremos um incêndio. Esse mesmo conjunto de condições não é, entretanto, necessário, dado que incêndios podem ser causados por vários outros conjuntos de elementos.

Assim, entendo que Mackie apaga a distinção entre causas e condições, ao menos analiticamente. As causas são elementos de um conjunto de condições, de forma que as condições podem ser vistas como causas, e vice-versa. No exemplo de Mackie, o curtocircuito foi considerado a causa do incêndio e poderíamos usar o critério contrafactual humeano para reforçar essa conclusão: nas condições reais, tal como o evento se deu $^{15}$, se não tivesse ocorrido um curto-circuito haveria incêndio? A resposta é: não, não haveria o incêndio. Assim, poderíamos dizer que o curto-circuito foi a causa. No entanto, devemos ter em mente que o critério contrafactual pode ser usado com qualquer elemento do conjunto de condições. Por exemplo, se não houvesse materiais inflamáveis por perto, também não haveria incêndio.

Talvez o conjunto de condições que produz um evento inclua tudo que já tenha ocorrido no mundo, o que nos leva novamente à questão de se o mundo é determinista ou não. Como delimitar, então, um conjunto de elementos que será suficiente para a produção do efeito? Para a historiografia, a questão diz respeito à seleção de eventos e fatores que serão

\footnotetext{
${ }^{15}$ Ou seja, ceteris paribus. A inclusão da cláusula ceteris paribus para os contrafactuais é tema de disputas entre os historiadores. Sobre isso, ver WEINRYB, 2009, p. 112-3.
} 
incluídos dentro do conjunto de condições que levou até o resultado: ou seja, quais são os fatores relevantes? A ênfase no curto-circuito como causa do incêndio - mesmo que se reconheça a necessidade de outros elementos concomitantes - parece refletir considerações pragmáticas: no caso, o fator humanamente controlável. Para a história da ciência, em particular, essa questão diz respeito a quais fatores serão considerados como causas do desenvolvimento científico (se apenas elementos racionais, ou se também outros fatores como influências sociais, econômicas, valores morais, etc.), e a qual será a relevância relativa de cada um deles.

A determinação do que é ou não relevante na história toca na questão da objetividade dos relatos historiográficos e da existência de critérios de seleção absolutos - que independam do historiador - relacionados à relevância dos eventos sob consideração. Helge Kragh afirma que "não é possível identificar eventos que sejam significativos em si próprios, em sentido absoluto" (KRAGH, 2001, p. 59). A inexistência de critérios objetivos parece indicar que a seleção dos elementos que aparecerão num relato historiográfico dependerá da escolha de um sistema de referência subjetivo. Essa subjetividade do sistema de referência não torna, entretanto, a historiografia um empreendimento sem objetividade. Para A. Schaff, assim que o historiador escolhe um determinado sistema de referência - subjetivo -, recebe ao mesmo tempo um conjunto de critérios - objetivos - para a seleção dos materiais históricos, conjunto esse "que não pode ser arbitrário e subjetivo, mas antes tem uma natureza objetiva em função do sistema de referência em questão" (SCHAFF apud KRAGH, 2001, p. 65).

A escolha dos elementos relevantes - e, no nosso caso, dos avanços - dependerá do sistema de referência filosófico e historiográfico adotado pelo pesquisador. Esses sistemas de referência variam grandemente entre si, mas podem ser agrupados em torno de dois eixos (Miller, 2012, p. 43). O primeiro eixo é aquele relacionado ao papel causal de fatores intelectuais e não intelectuais na produção do conhecimento. Miller sugere que esse eixo pode ser representado como uma razão numérica entre os segundos e os primeiros. Assim, a posição internalista extrema (“0”) é aquela que "nega qualquer eficácia causal ao contexto sociocultural no desenvolvimento da ciência", como se essa se desenvolvesse "inteiramente de acordo com sua própria lógica interna" (ibidem). No outro caso limite ("infinito") está a posição externalista extrema, para a qual as mudanças na ciência se devem apenas ao "contexto não intelectual que circunda a atividade científica" (ibidem).

O segundo eixo é o aquele da finalidade da pesquisa. Em um extremo estão aqueles que tentam relatar a história "tal como ela realmente foi" e por isso tentam "[...] imergir no 
passado, com toda a sua embaralhada complexidade, assustados pelo fantasma do anacronismo [...]" (ibidem, 44). No outro fim do espectro está a posição presentista, que assume o anacronismo e tenta relacionar a história aos interesses presentes, sejam de caráter filosófico ou didático. As reconstruções racionais de Lakatos estão nessa posição.

A MCHC não se situa necessariamente em nenhum desses extremos. Em relação ao primeiro eixo, acredito que fatores intelectuais e não intelectuais influenciam, ambos, o desenvolvimento da ciência ${ }^{16}$. Quanto ao segundo eixo, farei algumas considerações sobre o anacronismo na história da ciência e sobre como a MCHC lida com ele.

\subsubsection{A historiografia whig e a MCHC}

O anacronismo é o "erro em que os eventos passados são interpretados de acordo com estruturas que não existiam na época" (NEWALL, 2009, p. 268). Na história da ciência, o anacronismo se manifesta como aquilo a que Herbert Butterfield deu o nome de historiografia whig. Originalmente, Butterfield criticava os historiadores constitucionalistas ingleses que enxergavam a história política inglesa como um avançar ininterrupto até o partido Whig. Esse uso original foi transposto para a historiografia da ciência como a tendência de se escrever a história tal como uma marcha de ideias até a situação atual da ciência. Existem quatro características da historiografia whig da ciência que podem ser criticadas (KRAGH, 2001, p. 105): (i) avaliação e concessão de status, (ii) formalização, (iii) coerência e racionalidade, avaliados de acordo com a concepção contemporânea daquilo que é o trabalho racional de um cientista, e (iv) antecipação.

A utilização da ciência atual como padrão e fim da ciência do passado pode levar a equívocos sobre o conteúdo da ciência e sobre as condições em que as práticas científicas do passado se desenvolveram. Tende-se, assim, a avaliar os eventos do passado com a ideia atual do que seja a ciência e seus fins sociais. Esse tipo de avaliação é perigoso por confundir os conceitos e objetos da ciência do passado e tratar os casos que não levam à ciência atual como

\footnotetext{
${ }^{16} \mathrm{O}$ problema da demarcação entre ciência e não ciência pode ser uma questão empírica dentro da MCHC. Ao ligar causalmente os avanços do caso estudado, teremos um retrato dos fatores que influenciaram o episódio. Se após vários estudos de caso for notado que aspectos sociais influenciam de maneira relativamente uniforme no tempo o desenvolvimento da ciência, pode-se afirmar que esses aspectos não devem ser desconsiderados quando de uma generalização do que é a ciência. A questão da demarcação e a seleção e ligação causal dos avanços são duas faces da mesma moeda, e influenciam uma à outra de maneira circular: o que se pensa sobre uma influenciará a outra. Não creio que isso seja um vício, mas antes uma virtude da MCHC - a possibilidade de unir História e Filosofia da Ciência num todo indissolúvel.
} 
tendo "se comportado mal” (LAKATOS, 1970, p. 107) em relação ao que deveria ter acontecido a partir de um ponto de vista posterior ao período em questão.

A segunda característica da historiografia whig da ciência é a formalização, em geral através de termos matemáticos modernos, de ideias e teorias que não utilizaram a matemática em sua formulação. Kragh dá como exemplo a apresentação através de equações das ideias de Aristóteles sobre o movimento dos corpos. Para ele, tal formalização é errada por ignorar o fato de que o Filósofo não representou suas conclusões através de equações, por introduzir termos que o próprio Aristóteles não utilizava e por sugerir que se pode comparar diretamente a sua ciência com a de Galileu e Newton, através das equações ${ }^{17}$.

Com a aplicação de padrões atuais na ciência do passado, tende-se a buscar, a partir de um ponto de vista historicamente posterior, coerência e racionalidade em todos os escritos de um autor. Isso não quer dizer que os autores do passado sejam incoerentes ou irracionais, mas apenas que a coerência e a racionalidade de seus trabalhos devem ser julgadas não de acordo com parâmetros extemporâneos, mas sim com a medida que é dada pela própria época em que esses trabalhos surgem. De fato, a aplicação de um padrão externo de coerência e racionalidade liga-se ao primeiro aspecto da historiografia whig mencionado acima: a partir da ideia atual do que seja a ciência é feita a classificação do trabalho dos cientistas em dois campos: coerente e racional, por um lado; e incoerente e irracional, por outro. A busca pela racionalidade da ciência atual naquela do passado faz com que os aspectos dessa última que não se encaixam nesses critérios anacrônicos sejam vistos ou como irrelevantes ou como portadores de uma racionalidade científica "cifrada" - exemplos dessas atitudes podem ser encontradas na relação com os escritos astrológicos de Ptolomeu ou aqueles alquímicos de Newton: algumas vezes são considerados reflexos irracionais da época, que devem ser perdoados; noutras, portadores de uma racionalidade "cifrada", algo que pode conter informações "científicas" (de acordo com a visão whig) apesar da aparência "não científica".

A ênfase na ciência atual como ponto de chegada da história da ciência pode intensificar a busca por precursores de ideias atuais. O problema disso não está necessariamente na antecipação de ideias científicas, que pode ocorrer, mas na retirada do precursor de seu contexto histórico. Tal ocorre muitas vezes com Aristarco, encarado como o

\footnotetext{
${ }^{17}$ Didaticamente, a formalização matemática pode ser um recurso valioso, desde que não se perca de vista o conteúdo e o contexto original da idéia. No capítulo 2, apresento uma situação, a de Aristarco de Samos e seu cálculo das distâncias, em que evito as longas provas geométricas originais a favor de uma apresentação mais concisa, porém fiel ao espírito da prova original, utilizando a matemática moderna. Creio que a formalização é um perigo maior em casos nos quais a própria base metafísica do avanço é alterada, como no caso da física aristotélica apresentada através de equações, sendo mais ou menos aceitável em casos de utilização de ferramentas matemáticas mais modernas em casos nos quais a matemática já era usada.
} 
precursor do copernicanismo: poucas vezes se leva em conta os motivos pelo qual sua hipótese heliocêntrica não foi adotada. Uma questão que surge disso é: em que sentido se pode dizer que Aristarco antecipou Copérnico?

O problema da antecipação de ideias científicas pode ser analisado de duas formas distintas. Na primeira, ele refere-se à retomada, em uma determinada época, de uma hipótese ou teoria sugerida no passado, que tenha ou não recebido a devida atenção dos contemporâneos quando de seu surgimento. Ao antecipador é creditado um poder quase sobrenatural de navegar entre o mar de erros dessa ciência superada e chegar, enfim, à verdade que seus contemporâneos não souberam alcançar. Fundamental nessa concepção, como se nota, é (i) a ideia de que a ciência do passado deve ser julgada pela ciência do presente, que contém toda a verdade, ou ao menos a ela se destina por caminhos considerados infalíveis, e (ii) a retomada de uma ideia do passado que tenha sido conhecida e utilizada, ainda que o cientista não cite suas fontes para essa retomada. Essa é uma visão simplista da antecipação - e, talvez por isso, bastante difundida - e se resume, basicamente, a buscar a "sabedoria dos antigos". Exemplos desse uso da antecipação pode ser encontrados em TERESI, $2002^{18}$.

Outra visão da antecipação baseia-se no fato de que a ciência de uma determinada época pode produzir avanços semelhantes a outros do passado, sem a necessidade de que o cientista mais atual sequer saiba que seu avanço já ocorreu em outra época. Nesse caso, a antecipação não se baseia na aceitação de uma hipótese ou teoria obsoleta a partir do ponto de vista da ciência anterior, mas na similitude entre os dois avanços em questão. Essa similitude pode ser avaliada a partir dos seguintes critérios: (i) utilização dos mesmos conceitos, com os mesmos referenciais empíricos, nos dois avanços; (ii) identidade ou quase completa coincidência dos tipos de avanço relacionados a cada um dos dois avanços; e (iii) identidade ou quase completa coincidência dos problemas aos quais os avanços em pauta procuram resolver.

Nesse sentido, a disputa acerca do conhecimento ou não, por parte de Copérnico, das ideias de Aristarco perde interesse para o nosso caso ${ }^{19}$. O que se torna mais interessante, então, é saber se há avanços no trabalho dos dois astrônomos que possam ser considerados

\footnotetext{
${ }^{18}$ Que, apesar disso, considero um bom livro por destruir, através de inúmeros exemplos, a visão de que os antigos não eram capazes de alcançar conhecimento científico, e que, por isso, pode ser útil como uma introdução à história da ciência antiga.

${ }^{19}$ Sobre dois pontos de vista opostos sobre se Copérnico conhecia ou não as ideias de Aristarco, ver AFRICA, 1961, e GINGERICH, 1985.
} 
semelhantes (e assim se poder dizer, de acordo com a segunda concepção de antecipação, que um antecipa o outro), e tal consideração só pode ser feita a partir da rejeição da visão whig da história da ciência, com a reflexão sobre os próprios avanços e os avanços circundantes. No caso de haver essa antecipação, surge o problema de quais sejam os determinantes para o surgimento de um avanço numa época e, posteriormente, numa outra.

A MCHC, tal como a entendo, tenta evitar essas quatro características de uma visão anacrônica da história da ciência. Quanto ao problema da avaliação e concessão de status, a MCHC não considera o estado atual da ciência como o fim da ciência anterior. Isso porque o próprio conceito de avanço exige que o foco seja a ciência tal como praticada em seu próprio contexto histórico. Por outro lado, como os avanços abrangem as várias práticas dos cientistas, com a MCHC podemos considerar aspectos que uma visão whig avaliaria como não científicos ou como eventos que pudessem ser desconsiderados por não levar à ciência atual.

$\mathrm{O}$ mesmo ocorre em relação à formalização: a MCHC pretende mostrar os avanços tais como eram entendidos em sua própria época, de forma que se torna supérfluo apresentálos através da lente posterior da formalização matemática ${ }^{20}$. Com efeito, a formalização da ciência do passado tira-lhe de seu contexto, o que dificulta a análise da sua força causal e de como ela foi gerada.

A pressuposição de um determinado tipo de coerência e de racionalidade, aquele que é considerado como expresso no método científico e no funcionamento das diversas instituições científicas da ciência moderna ou contemporânea - em poucas palavras, certo modo de se fazer ciência - não faz parte da MCHC. Essa pressuposição relaciona-se com a demarcação entre o que é científico e o que não é, ou seja, com o papel causal de fatores "internos" e "externos" na produção do conhecimento. Como vimos, a MCHC aceita a influência de ambos os fatores, e por isso não faz nenhuma pressuposição acerca da coerência e da racionalidade que a ciência de algum período deva apresentar, se comparada à ciência moderna ou contemporânea. Essas considerações são posteriores e não guiam a pesquisa, e a avaliação do caráter racional de uma empresa científica deve referir-se ao período estudado. Isso pode, por um lado, evitar o surgimento de escândalo diante da existência simultânea de aspectos religiosos e racionais na astronomia antiga e, por outro, possibilitar a análise apropriada da complexidade do pensamento antigo.

\footnotetext{
${ }^{20}$ Exceto, claro está, por razões didáticas.
} 
O perigo relacionado à antecipação de ideias científicas, a descontextualização, não ocorre na $\mathrm{MCHC}$, dado que os avanços são ligados causalmente como efeito dos anteriores e como causas dos próximos. Isso pode ser mostrado na figura 3. Um avanço se torna importante para a historiografia whig na medida em que conduz à ciência de um determinado período, de forma que todos os outros que não conduzam a certo estado de coisas são desprezados. Os avanços $A, B, C$ e $D$ representam o estado da ciência num tempo histórico $\mathrm{t}_{1}$; assumamos que os avanços $B$ e $C$ tiveram boa aceitação em t ${ }_{1}$, mas $A$ e $D$, não. $E$ representa a ciência num tempo $\mathrm{t}_{2} ; \mathrm{e} F$, em $\mathrm{t}_{3}$. Consideremos que a historiografia whig de $\mathrm{t}_{2}$ selecione, por qualquer motivo, apenas os avanços $B$ e $C$, que conduzem a $E$, e despreze $A$ e $D^{21}$. Suponhamos que, em $\mathrm{t}_{3}$, por uma mudança na filosofia da ciência e nos padrões historiográficos, o avanço $D$ seja considerado uma das causas, junto com $E$, do avanço $F$. Como $D$ não aparece na historiografia whig de $\mathrm{t}_{2}$, será considerado, na historiografia de $\mathrm{t}_{3}$, uma antecipação de $F$, algo que os historiadores em $\mathrm{t}_{2}$ desprezaram injustamente. Até aí, nenhum problema. $\mathrm{O}$ que se deve evitar em $\mathrm{t}_{3}$ é a consideração isolada de $D$, como se houvesse sido bem aceito em $\mathrm{t}_{1}$, quando não foi, e a desatenção às especificidades de $D$ que o ligam ao tempo em que surgiu, $\mathrm{t}_{1}$. A análise correta de $D$ deverá indicar os motivos pelos quais não foi bem aceito na época em que surgiu ( $\left.\mathrm{t}_{1}\right)$. Na MCHC, podemos mostrar a especificidade de um dado avanço em relação à sua época, ou seja, sua relação com os outros avanços contemporâneos, e indicar a força causal do avanço em questão ${ }^{22}$.

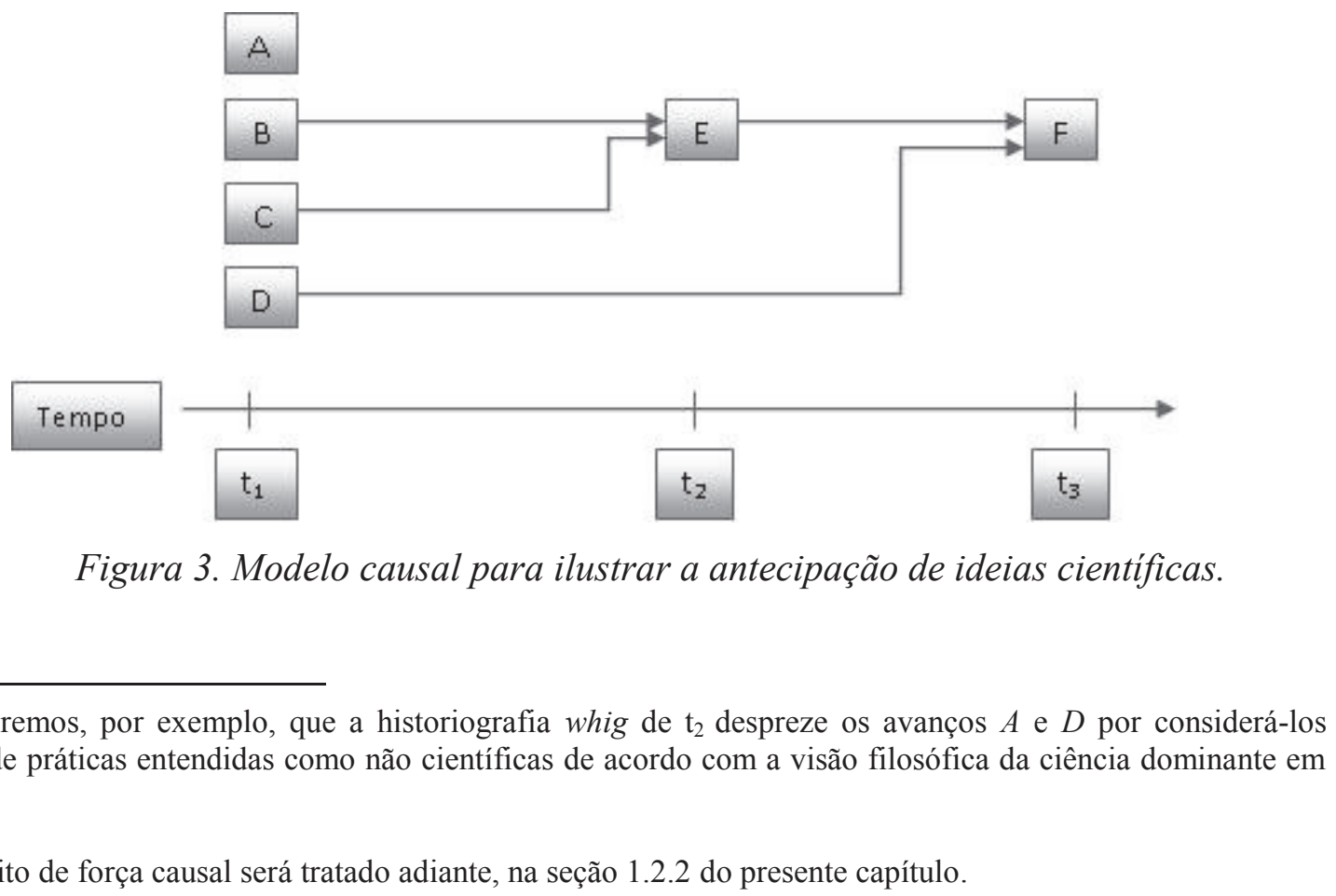

\footnotetext{
${ }^{21}$ Consideremos, por exemplo, que a historiografia whig de $\mathrm{t}_{2}$ despreze os avanços $A$ e $D$ por considerá-los advindos de práticas entendidas como não científicas de acordo com a visão filosófica da ciência dominante em $\mathrm{t}_{2}$.

${ }^{22} \mathrm{O}$ conceito de força causal será tratado adiante, na seção 1.2.2 do presente capítulo.
} 
Ainda que a MCHC procure evitar o anacronismo, nenhum estudo historiográfico ou que seja historicamente orientado pode evitar ao menos uma pequena parcela dele. $\mathrm{O}$ historiador ou pesquisador que use a história faz parte de sua própria época, e não pode "entrar" no passado e vê-lo tal como o viam os atores históricos. Além disso, na história e filosofia da ciência há o problema dos termos: como falar de "ciência", "cientista" e sobre as várias disciplinas no estudo de períodos históricos que não utilizavam essas categorias?

Existem duas opções para quem quer utilizar conscienciosamente o termo "ciência" (e seus correlatos "cientista" e as várias disciplinas): (i) utilizar algum critério de demarcação filosófico e universal, e (ii) considerar como "ciência" aquilo que era assim visto em sua época. Ambas são problemáticas. Critérios de demarcação universais têm o defeito de serem quase sempre baseados em uma disciplina científica específica (em geral, a física), e de excluírem da história da ciência manifestações que não eram avaliadas em sua época de modo diferente das disciplinas que hoje entendemos como científicas. Um exemplo disso é a astrologia. Ptolomeu escreveu seus quatro livros sobre astrologia (o Tetrabiblos) considerando que ela era um dos "dois meios de predição através da astronomia" (BARTON, 1994, p. 60). Para ele, a astrologia possuía o mesmo caráter conjectural da medicina, por causa dos inúmeros fatores que podem variar de indivíduo para indivíduo. De fato, a astrologia não era contraposta à astronomia, pois "[...] não havia nenhum conjunto privilegiado de disciplinas que gozavam um alto status por causa de seu acesso especial à verdade, como é o caso com a ciência de hoje" (ibidem, p. 6).

A ideia de se considerar como ciência o que era assim entendido em sua época instaura uma visão relativista da natureza da ciência. Na base dessa ideia está a pressuposição de que algo como a "ciência" sempre existiu em todas as culturas de todas as épocas, ligada seja a um, seja a outro tipo de prática social, econômica ou cultural, que devem ser levados em conta na sua apreciação. Uma das dificuldades que essa abordagem tenta resolver é o do status da astronomia babilônica e de seus praticantes:

[...] Os "astrônomos" e "matemáticos" da antiga Babilônia só podem ser considerados cientistas se isolarmos e interpretarmos as suas atividades científicas sem referenciar o contexto institucional (social e religioso) que lhes deu origem. Eles não se consideravam cientistas, muitos menos astrônomos e matemáticos (KRAGH, 2001, p. 29).

Ainda que tal visão pareça inofensiva, se levada ao extremo faria com que a história da ciência se apresentasse como um caleidoscópio de "ciências", que muitas vezes não guardariam nenhuma semelhança com a "ciência" praticada em outra época e local. Tal 
relativismo impediria qualquer estudo filosófico da ciência, com a aplicação de categorias como "método", "observação", "teoria" etc. Creio que, nesse extremo, os prejuízos seriam maiores do que os ganhos.

Como as duas posições têm suas qualidades e defeitos, creio que o melhor a se fazer é aceitar a dose - talvez inevitável - de anacronismo e tentar, de resto, evitar os riscos da historiografia whig que mencionei acima. Usarei, então, os termos "ciência", "cientista" etc., com a consciência de que, embora anacrônicos, são indispensáveis para a análise da ciência do passado. Mesmo com todo o cuidado em mostrar os diversos componentes da ciência do passado, haverá algum anacronismo; como afirma Nicolas Jardine,

[...] é difícil ver como historiadores da ciência antiga, medieval e moderna poderiam evitar totalmente o anacronismo: pois a aliança das disciplinas a que chamamos 'ciência' foi consolidada apenas nas primeiras décadas do século XIX (JARDINE, 2009, p. 293).

Tudo isso considerado, a MCHC utiliza uma abordagem unificacionista da causalidade, qual seja, a concepção condicional tal como proposta por Mackie. Isso significa que os avanços são ligados entre si causalmente, ou seja, são entendidos como elementos necessários de um conjunto suficiente para a produção de um novo avanço. O esquema INUS de Mackie permite que se trabalhe com uma ampla variedade de elementos causais, fazendo com que ele seja o ideal para que se trabalhe com os avanços, que, como vimos, abrangem uma ampla gama de práticas dos cientistas, tanto num nível macroscópico quanto num microscópico.

\subsubsection{Força causal dos avanços}

Podemos considerar que os avanços estão relacionados causalmente entre si, ou seja, um avanço é causa ou efeito de outro. Como a MCHC busca representar as práticas dos cientistas através dos avanços, e como essas práticas adquirem diferentes graus de aceitação com o passar do tempo, é útil considerarmos a força causal dos avanços. Pessoa Jr. define a força causal de um avanço como

[...] a potencialidade de que ele influencie a aparição de outros avanços, ou de que ele afete a força causal de outros avanços (mediado, obviamente, pelos cérebros e mãos dos cientistas, e pelas suas interações sociais e institucionais) (PESSOA JR. 2011, p. 227). 
A força causal de um avanço é uma mistura de considerações cognitivas e sociais. A discussão sobre os critérios objetivos de avaliação de teorias foi salientada por Kuhn que, ao se defender da acusação de que sua filosofia não proporcionava critérios de seleção entre teorias rivais, elabora uma lista com cinco valores cognitivos usados pelos cientistas na escolha de teorias: precisão, consistência interna e externa, amplitude de alcance, simplicidade, e fertilidade (KUHN, 1977, p. 322). A partir dos valores cognitivos, Hugh Lacey formula o ideal da imparcialidade: para que uma teoria seja aceita corretamente para um domínio específico, deve, em relação aos dados empíricos, "manifestar os valores cognitivos em alto grau de acordo com os mais rigorosos padrões disponíveis" (LACEY, 1999, p. 249).

Podemos dizer que quanto mais um avanço satisfizer os valores cognitivos, maior a força causal do avanço, pois ele tende a descrever melhor o mundo (ou, no caso de avanços metodológicos, a facilitar uma melhor descrição do mundo) e sugerir novas hipóteses e ideias, ou seja, tende a ter mais capacidade de gerar novos avanços, manifestando, assim, o valor cognitivo "fertilidade". Da mesma forma, quanto maior for o valor social de um avanço, maior sua força causal. Isso porque avanços que gozam de ampla aceitação, por fazerem parte de alguma tradição de pesquisa importante, tendem a gerarem mais avanços do que aqueles que não são aceitos pela comunidade científica. Com isso, um avanço pode manifestar todos ou alguns dos valores cognitivos da lista de Kuhn em alto grau e, no entanto, ter pouca força causal, por não ser parte de determinada tradição de pesquisa. Um exemplo disso é o destino do sistema astronômico proposto por Girolamo Fracastoro, seu Homocentrica, de 1538. A intenção de Fracastoro era eliminar os excêntricos e epiciclos do sistema ptolomaico, criando uma descrição mais simples dos movimentos dos astros (DREYER, 1953, p. 296-301). Para isso, criou uma teoria baseada nas esferas homocêntricas de Eudoxo e Calipo, que procurava dar conta dos aspectos empíricos então conhecidos - incluindo o movimento do apogeu solar que era desconhecido por Ptolomeu (Evans, 1998, p. 215, 231). No entanto, ainda que pretendesse ser mais simples e fosse empiricamente adequado, o sistema de Fracastoro foi completamente desprezado pelos contemporâneos por, entre outras coisas, tentar ressuscitar uma tradição anterior e considerada inferior à de Ptolomeu. Mesmo hoje, não há traduções de seu texto para línguas modernas.

A mudança - seja aumento ou diminuição - da força causal de um avanço reflete a transformação na aceitação e no status desse avanço com o passar do tempo. Como aponta PESSOA JR. (ibidem, p. 228), a força causal de um avanço teórico pode aumentar conforme uma ideia é transformada primeiramente numa hipótese e depois numa tese bem aceita numa 
teoria, principalmente se essa teoria se mostrar empiricamente adequada e for apoiada pela comunidade dos cientistas. Brannigan faz uma consideração semelhante acerca das descobertas científicas. Para ele, as descobertas não são um ato único, não “"ocorrem’ ou 'acontecem' simplesmente, mas são produções definidas e reconhecidas socialmente" (BRANNIGAN, 1984, p. 111), ou seja, a força causal e o reconhecimento das descobertas variam com o tempo e são relacionados com a forma pela qual uma realização científica é julgada pela comunidade.

$\mathrm{Na} \mathrm{MCHC}$, a força causa de um avanço é estimada através de um número, que vai de 0 a 1. Essa medida é subjetiva, mas permite que se possa descrever grosseiramente como o avanço era avaliado pelos cientistas em uma determinada época, o que pode ajudar também no estudo das relações sociais entre eles. Na presente dissertação, não farei estimativas da força causal dos avanços, dado que o problema da transmissão do conhecimento científico nas (e entre as) sociedades antigas ainda é pouco estudado ${ }^{23}$.

\subsection{Contrafactuais}

Segundo o esquema INUS de causalidade, um conjunto de causas é suficiente, mas não necessário, para a produção do efeito. Assim, podemos nos perguntar sobre a possibilidade de outro conjunto de causas produzir o mesmo efeito. No caso da historiografia, isso significa o recurso aos contrafactuais. $\mathrm{Na} \mathrm{MCHC}$, o uso dos contrafactuais está relacionado à utilização dessa noção de causalidade.

Contrafactuais são proposições condicionais subjuntivas nas quais o antecedente é falso $^{24}$. Na historiografia, os contrafactuais geralmente assumem a forma "se não tivesse

\footnotetext{
${ }^{23}$ Ver as notas 38 e 49.

${ }^{24}$ A relação entre condicionais que utilizam o modo subjuntivo e os contrafactuais é tema de controvérsia. Alguns autores consideram que ambos são idênticos, enquanto outros assumem uma noção ampla de contrafactuais em que mesmo proposições em modos que não o subjuntivo (como, por exemplo, "Se eu regar essa planta, ela irá brotar”) são consideradas como contrafactuais. Sobre isso, ver HOERL, MCCORMACK \& BECK (2011, p. 1-16).

Da minha parte, acredito que a caracterização dos contrafactuais através de proposições no modo subjuntivo impede a confusão com as implicações materiais (condicionais do tipo 'P $\rightarrow \mathrm{Q}$ ' (se $\mathrm{P}$, então $\mathrm{Q}$ )). Como as implicações materiais são verdadeiras sempre que o antecedente for falso, isso faria com que qualquer contrafactual fosse verdadeiro, pois nele o antecedente é falso, por definição. Como a minha intenção é mostrar a ligação dos contrafactuais com a causalidade, isso equivaleria a afirmar que qualquer atribuição causal é verdadeira.

Contudo, uma solução possível para o problema do valor de verdade dos contrafactuais e do uso do modo subjuntivo para os condicionais é dada por MACKIE, 1962: contrafactuais são melhor entendidos se
} 
ocorrido A, então não haveria ocorrido B”, em que A e B são eventos históricos. Apesar da resistência de muitos historiadores, que alegam que os contrafactuais são inúteis por lidarem com ficções, e não $\operatorname{com}_{\text {fatos }}{ }^{25}$, os contrafactuais têm sido bastante usados, inclusive na história da ciência. Whewell afirmava que a química teria se desenvolvido da mesma forma se "[...] o progresso da verdadeira ciência tivesse começado antes" (WhEWELL, 1857, p. 233), isto é, se a alquimia não tivesse existido. Kuhn utiliza os contrafactuais para mostrar a independência das pesquisas de Max Planck e de Albert Einstein: para Kuhn

[...] O que levou Einstein ao problema do corpo negro em 1904 [...] foi a coerente elaboração de um programa de investigação iniciado em 1902, tão independente do de Planck que haveria conduzido quase com certeza até a lei do corpo negro mesmo que Planck jamais houvesse existido (KUHN, 1987, p. 202).

Recentemente, os contrafactuais na história da ciência foram tema de uma coletânea na revista Isis (RADICK et al., 2008). Também Edward Grant recorre aos contrafactuais para se perguntar se "[...] poderia ter havido uma revolução científica no século XVII se nunca se tivessem traduzido para o latim inúmeros textos de ciência e de filosofia natural greco-árabes [...]" (GRANT, 2002, p. VII).

No esquema INUS, podemos utilizar os contrafactuais de duas formas. A primeira está ligada à noção de causa que opera dentro de cada condição. Uma causa é uma parte necessária de um conjunto de fatores suficiente para produzir o efeito. No interior desse conjunto, então, se não houvesse a parte (a causa), não haveria o conjunto suficiente e não haveria o efeito. Esse uso nada mais é do que um reflexo da definição contrafactual de causalidade dada por Hume, de forma que sempre aparecerá quando falarmos em causas na história.

considerados como argumentos incompletos, e não como proposições. Assim, um contrafactual pode ser sustentado através da adição de premissas que completem o argumento (ainda que nem sempre se possa completá-lo, tanto por ignorância dos fatores envolvidos, quanto pela impossibilidade de relatar um número muito elevado, ou mesmo infinito, deles). Por exemplo, no caso mencionado por Mackie, o das causas do incêndio na casa, o contrafactual poderia ser sustentado através de um argumento mais ou menos assim:

- Curto-circuitos geram incêndios em materiais inflamáveis, caso não haja equipamentos de segurança que evitem o fogo;

- Houve um curto-circuito na casa;

- Não havia equipamento de segurança;

- (Aqui outras premissas que indicam fatores causadores de incêndios, e que não estavam presentes na situação em pauta, podem ser adicionadas);

- Sem o curto-circuito, não haveria o incêndio.

\footnotetext{
${ }^{25}$ A oposição aos contrafactuais é, na verdade, uma oposição ao uso da causalidade na historiografia - atitude, portanto, dos excepcionalistas. Na opinião de Steve Fuller, "historiadores que se opõem aos contrafactuais não são sérios [hardheaded] com relação aos fatos, mas sim ingênuos [softheaded] sobre a causalidade" (FULLER, 2008, p. 577).
} 
A segunda forma de utilização dos contrafactuais é a da postulação de cenários alternativos que poderiam produzir o mesmo efeito. Como o conjunto de causas que gera o efeito é apenas suficiente, fica aberta a possibilidade de que haja outro(s) conjunto(s) que gerem o mesmo efeito. No caso do incêndio, antes da descoberta de que houve um curtocircuito, existia a possibilidade de que as condições causais fossem outras (por ex.: o dono ateia fogo à casa para conseguir o pagamento do seguro + materiais inflamáveis na casa + ausência de equipamentos de segurança, etc.).

Historiográfica e filosoficamente, essa segunda utilização dos contrafactuais apresenta o problema dos limites a que deve obedecer para que seu uso seja fértil. Para evitar uma exploração dos contrafactuais em que o uso da imaginação sem freios tire todo o seu valor analítico ("se a lua não existisse, como seria a astronomia grega?"), já se propôs que o limite de sua utilização seja aquele das possibilidades abertas no passado ${ }^{26}$. Niall Ferguson afirma que apenas contrafactuais plausíveis sejam aceitos, e define "plausíveis" como "[...] aquelas alternativas que podemos mostrar que os contemporâneos consideraram, com base em evidências contemporâneas." (FERGUSON, 1997, p. 86).

Outra solução é proposta por PESSOA JR. (2013), a partir da distinção entre mundos logicamente, fisicamente e causalmente possíveis. O autor parte da semântica e metafísica dos mundos possíveis de Saul Kripke, David Lewis, Alvin Plantinga e outros, criada para resolver

\footnotetext{
${ }^{26}$ Falar em possibilidades na história da ciência leva à questão de como se dá o progresso na ciência. De um lado, temos a visão de que a ciência avança em direção à verdade. Essa é uma postura realista que afirma a existência de uma realidade, a natureza una que age como o "atrator" para as teorias científicas. Pessoa Jr. indica que essa concepção de progresso científico foi defendida, entre outros, por Popper:

Ao observar o progresso do conhecimento científico, muitos são levados a afirmar que, embora não saibamos se estamos distantes ou pertos da verdade, podemos (e muitas vezes conseguimos) nos aproximar cada vez mais dela. [...]

De fato, não há motivo para deixar de dizer que uma teoria corresponde aos fatos melhor do que outra. $[\ldots]$

[A]credito que simplesmente não podemos dispensar algo como a ideia de uma melhor (ou pior) aproximação da verdade.

Isso sugere que estamos combinando aqui as ideias de verdade e de conteúdo numa única noção, de grau de correspondência com a verdade, de maior ou menor similaridade com respeito à verdade; ou, para empregar um termo que já mencionamos, a ideia (ou graus) de verossimilhança, diferente da probabilidade. (POPPER apud PESSOA JR., 2006, p. 165).
}

Nesse sentido, os vários cenários contrafactuais levariam todos à mesma ciência do mundo real e atual, ou ao menos uma muito parecida.

De modo diverso, Kuhn afirmava que a ciência não tem seu progresso dirigido a um fim. Esse progresso, ainda que unidirecional e irreversível, não é teleológico, pois ocorre "sem uma verdade científica permanentemente fixada" (KUHN apud ibidem, p. 166). Por ser unidirecional e irreversível, o progresso científico tal como visto por Kuhn não é relativista, mas acontece de acordo com determinados valores cognitivos. 
problemas acerca do significado de expressões modais como "necessário", "possível”, “contingente" e "impossível”. Mundos possíveis são

Modos como as coisas podem ser. Por exemplo, tal como as coisas são, Sócrates era grego. Mas Sócrates poderia ter sido egípcio. Assim, diz-se que há um mundo possível no qual Sócrates era egípcio, e diz-se que no mundo atual (o modo como as coisas são) Sócrates era grego (MURCHO, 2006, p. 532).

Um mundo logicamente possível é aquele em que não há contradição lógica. Mundos logicamente possíveis podem violar as leis da física, desde que não apresentem contradições lógicas. Já um mundo fisicamente possível é aquele em que as leis da física são mantidas, de forma que todos os mundos possíveis obedecem às mesmas leis - que podem, porém, envolver condições iniciais e de contorno distintas das do Universo atual. Por fim, um mundo causalmente possível obedece as leis atuais da física e as condições iniciais de nosso Universo, pressupondo que as transições entre estados não sejam estritamente deterministas, e pode ser definido como "uma possibilidade (temporal) futura com referência a algum instante do passado real do Universo" (PESSOA JR., 2010a, p. 44). Para a historiografia, apenas os mundos causalmente possíveis têm valor ${ }^{27}$, já que permitem que se considere possibilidades históricas concretas. Tanto a solução de Ferguson quanto a de Pessoa Jr. são consistentes com o esquema INUS de causalidade que vimos acima.

Nesses termos, os contrafactuais - com os cenários alternativos ${ }^{28}$ que deles advêm são um recurso metodológico da $\mathrm{MCHC}$, e sua utilização é outro modo de mostrar a ligação causal dos avanços. Como aponta Pessoa Jr., "[...] a noção de causa nas ciências históricas só pode ter função explicativa se se tiver uma ideia das histórias possíveis que não se concretizaram". (PESSOA JR., 2000, p. 176). Os contrafactuais podem também indicar o caráter inevitável ou não de certos eventos: é nesse sentido que FULLER (2008) se pergunta sobre o que aconteceria se a Revolução Científica não tivesse ocorrido no século XVII. Para ele, a resposta a essa questão só pode ser dada através do estudo das causas que atuavam na ciência do século XVI. É justamente o estudo das causas das mudanças científicas o objeto da $\mathrm{MCHC}$.

\footnotetext{
${ }^{27}$ Há, entretanto, historiadores que defendem que mesmo os chamados "contrafactuais de mundos milagrosos" [miracle world counterfactuals] - que expressam possibilidades em mundos apenas logicamente ou fisicamente possíveis - são úteis para a historiografia como ferramentas analíticas "quando a questão é se o mesmo fator duradouro influencia significativamente um dado sistema" (WEINRYB, 2009, p. 114).

${ }^{28}$ Enquanto os contrafactuais são úteis por indicarem possíveis caminhos alternativos pelos quais um dado avanço poderia ser obtido, os casos de descobertas independentes são valiosos por mostrarem caminhos alternativos reais, que de fato levaram ao mesmo avanço. Sobre isso, ver PESSOA JR., 2008.
} 


\section{Estudos de caso utilizando a MCHC}

Para ilustrar a método delineado acima, apresento três estudos de caso feitos com a MCHC, todos de autoria de Pessoa Jr. O primeiro é uma análise dos primórdios da ciência do magnetismo (PESSOA JR., 2010c); o segundo, da descoberta da radiação infravermelha (idem, 2010b); e o terceiro, do surgimento da física quântica (idem, 2000). Nos três estudos, inicialmente se faz a seleção e catalogação dos avanços a partir de fontes primárias e secundárias. Em seguida, os avanços são ligados causalmente, buscando mostrar como cada avanço foi condicionado por algum(uns) avanço(s) anterior(es). Com o mapa causal pronto, é possível perceber algumas estruturas e padrões do desenvolvimento científico.

No primeiro artigo, Pessoa Jr. faz a modelagem causal da ciência do magnetismo num período de tempo que vai desde a Antiguidade até o século XVI, e que abrange três grandes áreas geográficas, a América Central, a China e a Europa, que representam três vias alternativas dessa ciência. Essas três histórias possíveis são factuais, e por isso os contrafactuais não são explorados nesse artigo. Após selecionar os avanços a partir das fontes, Pessoa Jr. faz a concatenação deles e chega à figura 4, que representa o modo como os avanços foram causa e efeito de outros avanços. As épocas em que os avanços foram criados são representadas pela linha acima dos quadrados, que por sua vez representam os avanços. As letras A, C e E referem-se aos avanços obtidos na América Central, China e Europa, respectivamente. As setas e os conectores lógicos indicam as ligações causais e as conjunções de causas para o surgimento do novo avanço. Diferentes convenções são usadas para a diferenciação dos avanços: na parte superior e mediana, a linha tracejada indica "avanços generalizados", que indicam a presença de avanços de um mesmo tipo que aparecem nas várias alternativas e que mostram o que

[...] haveria de "essencial" (para utilizar uma terminologia aristotélica) nas diferentes espécies de avanços [...]. No avanço generalizado, abstraem-se as diferenças "acidentais" que ocorrem nas diversas histórias possíveis do episódio (PESSOA JR., 2010c, p. 203).

$\mathrm{Na}$ parte inferior, os avanços inseridos em retângulos de linha dupla representam aqueles que ocorreram na China, e os de linha simples, na Europa. A parte do meio representa apenas os avanços chineses. 

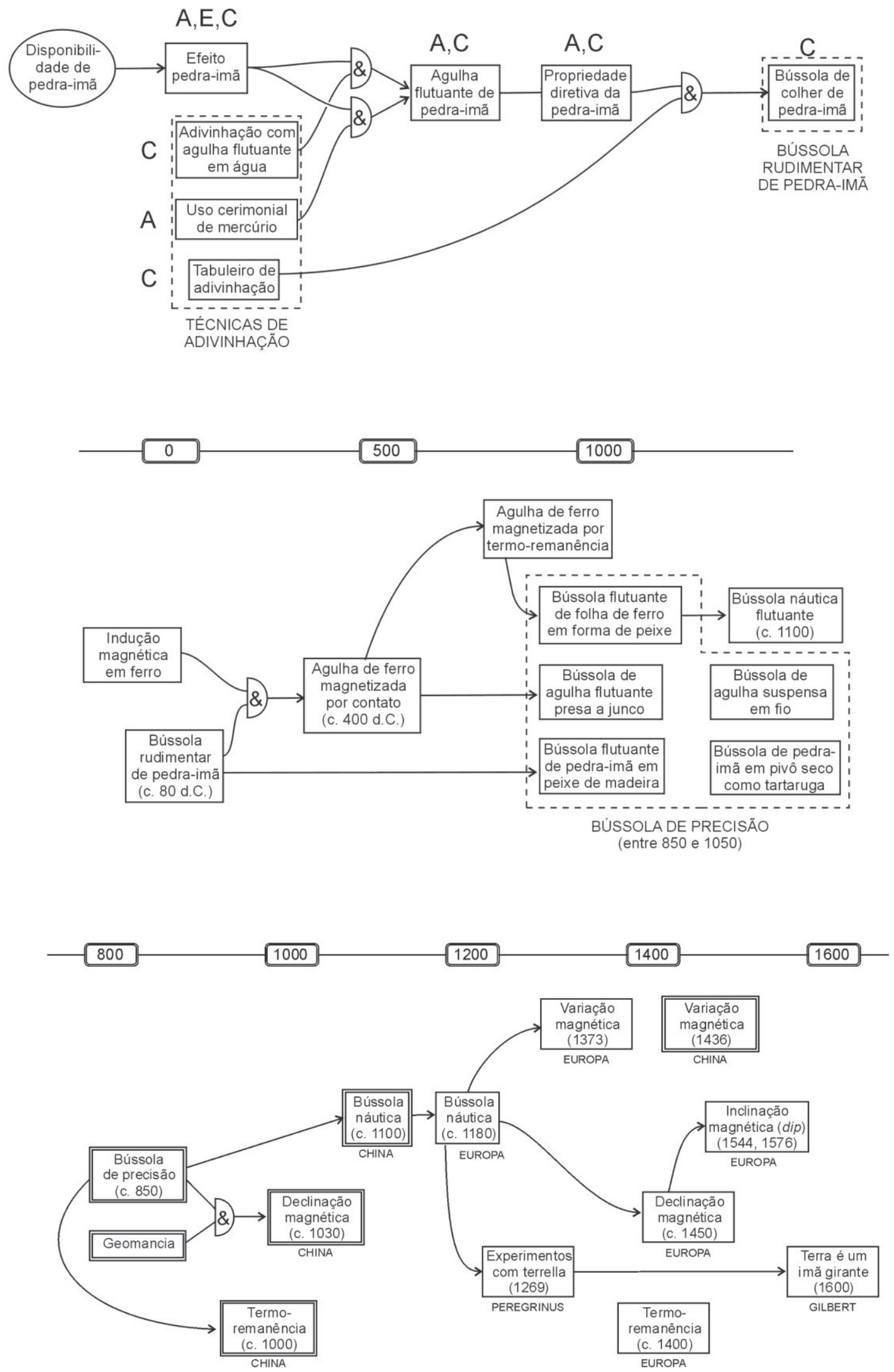

Figura 4: Modelos causais da ciência do magnetismo. 
A análise do mapa causal indica a presença de gargalos, avanços sem os quais o desenvolvimento da ciência do magnetismo ficaria travado. Podemos entender esses gargalos como as partes necessárias de um conjunto suficiente para a produção do efeito; logo, sem elas, o último não é produzido. Um exemplo disso é o avanço "propriedade diretiva da pedraímã”, que foi alcançado na América Central e na China, mas não na Europa (onde foi importada um milênio depois). Uma das características do mapa, que Pessoa Jr. considera ser própria "da ciência nascente" (ibidem, p. 13) é a presença de avanços de tipo cultural, como as "técnicas de adivinhação" que aparecem na parte superior da figura, e a "geomancia", na parte inferior. Outra conclusão do estudo é que a comparação do modelo causal dos primórdios de uma ciência com aquele de uma ciência madura indica conexões causais mais simples, em que um avanço isolado causa outro, enquanto na última essas conexões tendem a ser múltiplas.

O segundo exemplo de utilização da MCHC pretende mostrar a "Estrutura causal da descoberta do calor radiante" (PESSOA JR., 2010b). O estudo foca-se na descoberta do "calor radiante", ou infravermelho, por William Herschel, e nas teorias rivais que foram propostas para explicar o fenômeno. O método é basicamente o mesmo daquele descrito acima: seleção dos avanços, ligação causal dos mesmos e análise. A principal diferença deste exemplo em relação ao anterior é a apresentação das mudanças temporais da força causal, representada na figura 5 como a espessura dos blocos: quanto mais espesso o bloco, maior a força causal do avanço. As forças causais dos avanços foram estimadas com base na "aceitação média do avanço por parte da comunidade científica interessada no assunto" (PESSOA JR., 2010a, p. 64).

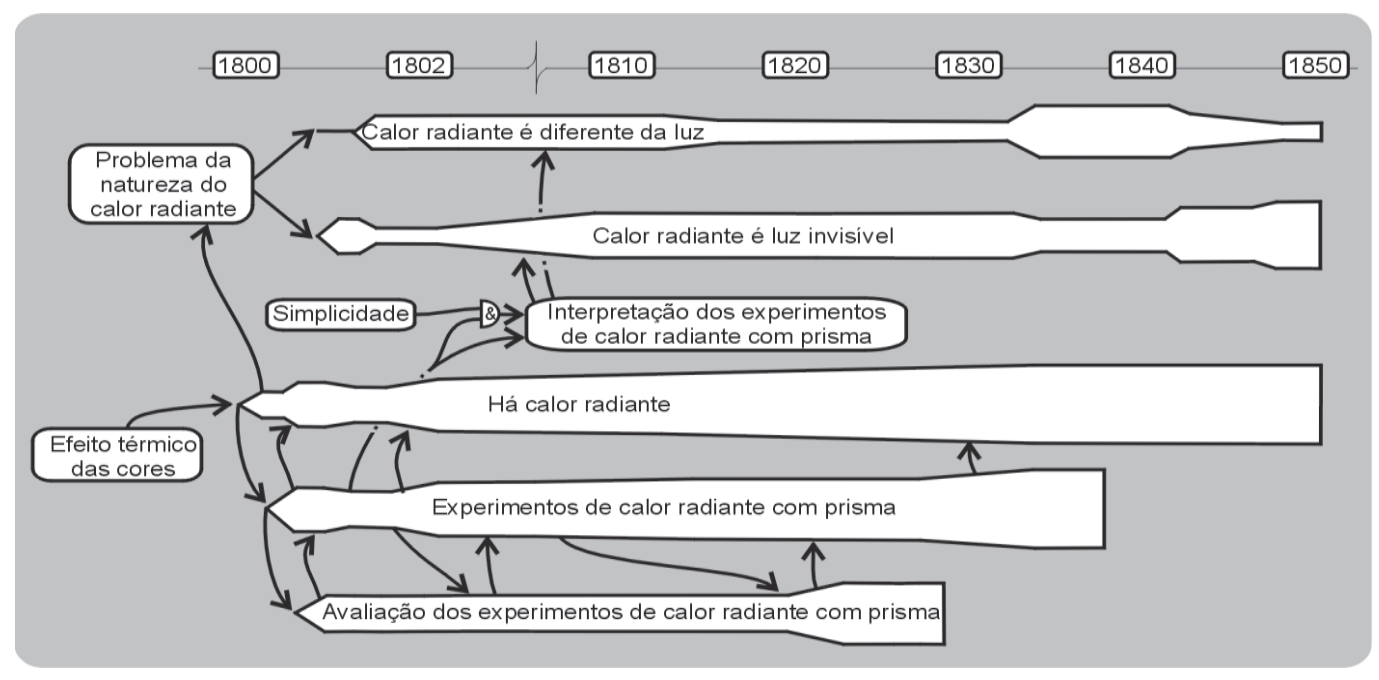

Figura 5. Modelo causal da área de calor radiante, com indicação das forças causais dos avanços. 
Um exemplo dessa mensuração da força causal pode ser dado através do avanço "Há calor radiante". Pessoa Jr., dá um valor inicial de 0,3 quando da primeira proposição do avanço por Herschel. Esse valor aumenta para 0,5 com outra publicação mais detalhada do mesmo cientista. Em 1801, John Leslie refaz os experimentos de Herschel e não obtém os mesmos resultados, o que reduz a força causal do avanço para 0,4. Por fim, outras repetições bem-sucedidas dos experimentos elevam o valor da força causal para 0,9. Como vimos, considerações de ordem cognitiva e social entram na mensuração da força causal.

Na conclusão do artigo, Pessoa Jr. resume a estrutura da descoberta do calor radiante, e lança o chamado para outros estudos acerca da universalidade dessa estrutura para outras descobertas:

[...] um fato proposto surgiu inesperadamente a partir de certos experimentos. Pela parte teórica, imediatamente se coloca a questão sobre qual é a natureza do fato, e diferentes explicações são desenvolvidas, afetadas pela interpretação dos experimentos. Os experimentos começam a ser realizados logo que o novo fato é descoberto, e inicialmente surgem resultados diversos, conforme o cientista envolvido. A avaliação da qualidade destes experimentos é parte importante da discussão.

[...] A comparação com descobertas de outros fatos poderá esclarecer em que medida a estrutura causal apresentada é geral (PESSOA JR., 2010b, p. 8-9).

Os contrafactuais são explorados num outro estudo de caso utilizando a MCHC: "História contrafactuais: o surgimento da física quântica" (PESSOA JR., 2000). Nesse artigo, o autor analisa a situação da física a partir da metade do século XIX e postula, com base nas possibilidades históricas abertas representadas pelas várias pesquisas sendo então desenvolvidas, diversos cenários contrafactuais que levariam à física quântica.

\section{Modelagem causal da astronomia antiga}

A minha intenção nesta dissertação é descrever a astronomia antiga utilizando a MCHC. O que se entende por "astronomia antiga" varia de autor para autor (alguns, como por exemplo RUGGLES \& URTON [2007], tratam da astronomia pré-histórica utilizando a arqueologia, numa disciplina chamada "arqueoastronomia"), mas, em geral, costuma-se começar com os primeiros registros sistemáticos de eclipses pelos babilônios, por volta do século VII AEC (embora haja evidência de observações astronômicas babilônicas já por volta do século XII AEC [SCHIAPARELLI, 1925, p. 66]), e passar pela astronomia grega de Eudoxo, 
Aristóteles e Aristarco, chegando até Ptolomeu. Seguirei essa abordagem nesta dissertação, e tratarei da astronomia dos babilônios, egípcios e gregos, com foco naquela dos últimos, compreendida entre os séculos VI AEC (época do surgimento da filosofia grega) e III AEC (século em que Aristarco lança suas ideias). Essa abordagem mais voltada para uma disciplina é aquilo que Kragh chama de história horizontal da ciência ${ }^{29}$ : aquela em que se estuda "o desenvolvimento através do tempo de um dado assunto restrito; uma especialidade científica, uma área de problemas ou um tema intelectual" (KRAGH, 2001, p. 91).

A astronomia antiga tem sido pouco utilizada como fonte de estudos de caso para a filosofia da ciência, exceto, talvez, por estudos sobre a astronomia de Aristóteles e Ptolomeu. Creio que seja de fundamental interesse para a história e filosofia da ciência o estudo das mudanças históricas no caráter da astronomia. A MCHC é de interesse nesse estudo ao indicar como os vários tipos de ideias e práticas se ligaram entre si no decorrer do tempo.

No próximo capítulo, farei uma breve história da astronomia, dos primórdios até Aristarco, para nela indicar os avanços que são modelados causalmente no capítulo 3.

${ }^{29}$ Em contraposição a uma história vertical da ciência, que apresenta uma "perspectiva de natureza mais interdisciplinar" (KRAGH, 2001, p. 91). 


\section{Capítulo 2}

\section{Avanços da astronomia antiga}

Neste capítulo, mostrarei os principais avanços da astronomia antiga, desde os primórdios até Aristarco de Samos. Este capítulo consistirá numa apresentação dos avanços em ordem (quase sempre) cronológica, de forma a mostrar os dados que serão utilizados no modelo causal do próximo capítulo.

Como se verá, preferi dar enfoque à astronomia dos babilônios e à dos gregos (com algumas incursões pela astronomia egípcia). A razão disso é dupla: primeiro, as astronomias desses dois povos são as bases a partir das quais se desenvolvem aquelas de outras culturas, como a chinesa, influenciada pela astronomia babilônica, e a indiana, pela grega ${ }^{30}$ (ainda que possamos excluir a astronomia do Novo Mundo - a maia e a inca - do campo de influência babilônico-grego); segundo, incluir os avanços advindos de outros povos que não os babilônios e gregos, ainda que seja, por si só, uma tarefa nobre e que pretendo realizar em outros estudos, aumentaria imensamente a presente dissertação. Esse segundo motivo também é responsável pela exclusão, nesta dissertação, de uma consideração de avanços da chamada "astronomia megalítica", como Stonehenge, Sarmizegetusa e Callanish ${ }^{31}$.

\section{O nascimento da astronomia}

A astronomia é, provavelmente, a ciência mais antiga de todas. Os fenômenos celestes chamaram a atenção do homem desde tempos pré-históricos, e os primeiros registros escritos já mostram a preocupação e a busca da compreensão das mudanças no céu. Schiaparelli afirma que

O alternar-se rápido dos dias e das noites, o acontecimento mais lento, mas não menos importante [...], das estações, o retorno das fases lunares a intervalos regulados, e a variedade

\footnotetext{
30 “A astronomia da China recebeu um impulso da Babilônia em seus primórdios, e a astronomia clássica indiana desenvolveu-se, quase certamente, das primeiras teorias geométricas gregas” (THURSTON, 1994, p. ix).

${ }^{31} \mathrm{O}$ leitor que desejar saber mais sobre as astronomias não tratadas nesta dissertação pode encontrar informações em KrupP (2003), RUGGLES (2005), RUGGLES \& URTON (2007) e SELIN (2000).
} 
da iluminação noturna que delas derivam, devem ter sido, em todos os tempos e em todos os lugares, objeto de atenção e reflexão prática para o caçador, para o pastor e para o cultivador da terra (SCHIAPARELLI, 1925, p. 43).

A partir dessas observações celestes iniciais, este é o primeiro avanço que apresento: a observação de que os céus parecem se mover de leste para oeste ${ }^{32}$. Não se pode saber quando esse avanço ocorreu pela primeira vez. De fato, existem muitos avanços da astronomia antiga cuja data não pode dada com precisão. Já em períodos pré-históricos, as fases da Lua, os alinhamentos norte-sul e estimativas da duração das estações eram reconhecidos pelo ser humano que olhava para o céu ${ }^{33}$.

Ainda que seja difícil, se não de todo impossível, conhecer as motivações das primeiras observações e tentativas de compreender o céu, PANNEKOEK (1961, p. 19-20) distingue duas razões de ordem prática para elas: em primeiro lugar, o conhecimento do céu facilitaria a sobrevivência dos homens, ao indicar as melhores épocas para caçar, plantar e colher; em segundo lugar, permitiria a mensuração do tempo em dias, meses e anos, e a confecção de um calendário. De fato, os vários povos construíram seus próprios calendários, sendo que a maioria deles baseava-se nos ciclos lunares ${ }^{34}$. Entre esses vários calendários antigos, o egípcio merece atenção especial, dado que "provavelmente nenhum [calendário] continuou [a ser usado] por um período maior do que o egípcio" (NEUGEBAUER, 1983, p. 196). Para que se tenha ideia da longevidade do calendário egípcio, basta recordar que Copérnico o utiliza para datar suas observações em seu De Revolutionibus.

$\mathrm{O}$ calendário dos egípcios também era inicialmente lunar, com meses variando entre 29 e 30 dias, mas foi mudado por volta do início do terceiro milênio AEC, provavelmente por razões de controle fiscal (PARKER, 1974, p. 52), para uma estrutura bastante simples: o ano dura 365 dias, divide-se em 12 meses de 30 dias cada, com a adição de 5 dias após o $12^{\circ}$ mês. Por ser um calendário constante, sem intercalações de dias em certos anos (tal como no nosso calendário gregoriano, onde 1 dia é adicionado a cada 4 anos, exceto nos anos de passagem de

\footnotetext{
${ }^{32}$ Como aponta RUGGLES (2005, p. 68), as designações "leste" e "oeste" não se referem aos pontos cardeais exatos tal como os usamos atualmente, "mas pode[m] se referir ao que descreveríamos como uma variedade de direções ao redor do leste [e oeste] exato[s]".

33 Sobre isso, ver Kelley \& Milone (2005), Ruggles (2005) e Ruggles \& URTon (2007). Alguns historiadores, como Gordon Childe, propõem o estudo da história da ciência na pré-história, e afirmam que certos desenvolvimentos, como as ferramentas, envolvem o mesmo grau de conhecimento empírico e indutivo que o de uma ciência madura. Sobre isso, ver KRAGH, 2001, p. 32-33.
}

${ }^{34}$ Esses calendários utilizam o período sinódico da Lua, que é o intervalo entre duas Luas cheias. 
século não divisíveis por 4), foi utilizado por virtualmente todos os astrônomos antigos. No entanto, essa simplicidade custou o descompasso entre as estações e o calendário ${ }^{35}$. Outro calendário antigo, o babilônico $^{36}$, seguia inicialmente uma estrutura semelhante - a determinação do correto ciclo luni-solar para o calendário só seria atingida num estágio bastante avançado da astronomia babilônica (NEUGEBAUER, 1983, p. 200). Tanto o calendário egípcio quanto o babilônico são baseados nas observações dos céus e seus movimentos, e não em alguma teoria de alto nível ${ }^{37}$. NeUGeBAuER (ibidem, p. 40) afirma que "o calendário egípcio não pressupõe nenhuma astronomia sistemática".

A observação dos céus foi essencial para a produção de calendários que separavam o tempo em unidades como meses e anos. Mas outra divisão era tão importante quanto essas: a divisão do tempo em dias e noites. Por volta de 2150 AEC, os egípcios dividiam a noite em 12 horas "sazonais", determinadas pelo nascimento de certas estrelas durante a noite (PARKER, 1974, p. 53). Como as distâncias angulares entre as estrelas escolhidas para marcar as horas não eram iguais, as horas não tinham a mesma duração numa noite, e também variavam com as estações, dado que as noites são menores no verão. O dia era dividido inicialmente em 10 horas, com 2 horas a mais para o crepúsculo. Essas horas "sazonais", desiguais, foram transformadas, por volta do século XII AEC, em horas de duração igual, e PARKER (ibidem, p. 57) relata a existência de papiros em que a duração dos dias é sempre de 24 horas, com o valor extremo de noites com 6 horas e dias com 18 horas. Tanto os gregos como os romanos dividiam os dias em horas seguindo esse modelo.

A observação dos céus levou muitos povos antigos de todo o mundo a perceber determinados padrões nas estrelas: as constelações. Um desses padrões, a constelação da Ursa Maior, visível no hemisfério norte, aparece em mitos gregos, hebreus e siberianos, e também nas histórias das tribos da América do Norte, como os Cherokee. SCHAEFER (2006, p. 98)

\footnotetext{
${ }^{35}$ Em quatro anos, o calendário egípcio tinha aproximadamente um dia a menos em relação a um calendário solar preciso.

${ }^{36}$ Aqui, e em boa parte dessa dissertação, talvez fosse mais correto utilizar o adjetivo "mesopotâmico", mais abrangente do que "babilônico". No entanto, sigo a prática corrente dos historiadores da astronomia de designar toda a astronomia feita na Mesopotâmia, seja pelos sumérios, seja pelos assírios, seja pelos babilônicos propriamente ditos, como "astronomia babilônica". "Aquela que nós por conveniência e brevidade chamamos astronomia babilônica (e em geral a mesma coisa se pode dizer de toda a cultura babilônica) não teve o seu princípio na Babilônia" (SCHIAPARELLI, 1925, p. 50).

${ }^{37}$ Não pretendo tocar, por ora, no problema da primazia da teoria sobre a observação. Aponto apenas para o fato de que a confecção de um calendário pressupõe um conhecimento qualitativo de alguma espécie de ciclo dos céus (de modo que algum fenômeno celeste pode indicar o recomeço desse ciclo), mas não pressupõe um conhecimento quantitativo ou geométrico desses ciclos, com alguma teoria que diga como é o Universo e que permita fazer previsões detalhadas sobre vários desses fenômenos.
} 
afirma que a ubiquidade dessa constelação não se deve à semelhança do padrão estelar com um urso, mas que é fruto das primeiras migrações para o Novo Mundo, ainda no período Paleolítico (14.000 anos AEC), e que os povos migrantes levaram consigo esse modo de figurar a constelação. Com efeito, não se sabe muito sobre a gênese de muitas constelações (ainda que aquelas do hemisfério sul, desconhecidas na Antiguidade por gregos e babilônios, possam ter suas certidões de nascimento lavradas a partir de mapas celestes do início do período moderno), nem o porquê de certos padrões aparecerem em várias culturas, e outros não. De todo modo, os primeiros registros de constelações aparecem na Mesopotâmia por volta de $1.700 \mathrm{AEC}$, num texto onde são citadas quatro constelações, enquanto o conjunto que servirá de base àquelas gregas parece estar finalizado por volta de $1.100 \mathrm{AEC}$ (ibidem, p. 101). O sistema das doze constelações do zodíaco é um avanço babilônico, e surge no início do século IX AEC. SCHIAPARELLI (1925, p. 99) afirma que os babilônios costumavam designar a posição da Lua e dos planetas indicando as estrelas mais brilhantes perto das quais se encontravam, bem como as constelações desiguais que marcavam os meses a partir de seu nascimento helíaco (quando o Sol se punha). A necessidade de estabelecer um sistema metódico de mensuração levou a que se referisse a posição dos planetas ao círculo em que eles sempre faziam seu curso, e não mais às constelações de extensão angular desigual. Esse sistema será a base dos signos artificiais do zodíaco na eclíptica, cada um se estendendo igualmente por $30^{\circ}$ no céu, e que começa a ser usado na Babilônia no fim do século VI AEC (EVANS, 1998, p. 39). Essas divisões do céu são essenciais para as observações sistemáticas e para os primeiros estudos dos movimentos do Sol e da Lua. Entre os gregos, duas constelações (Órion e o Grande Urso) aparecem nos textos de Hesíodo e Homero, mas a primeira exposição sistemática das constelações é feita por Eudoxo em meados do século IV AEC, num texto que se perdeu, mas cujo teor é conhecido através da cópia feita em 270 AEC por Arato, em seu Fenômenos. A maioria das constelações gregas tem origem nas antigas constelações mesopotâmicas, e SCHAEFER (2006, p. 98) propõe que os gregos receberam as últimas depois de aproximadamente $500 \mathrm{AEC}$, pois antes disso se mencionava apenas duas constelações, mas antes de 400 AEC, quando o sistema de doze signos já era usado na Grécia. Não se sabe exatamente como se deu a transmissão dessas constelações dos babilônios para os $\operatorname{gregos}^{38}$.

\footnotetext{
${ }^{38} \mathrm{O}$ problema da transmissão de conhecimentos astronômicos entre a Mesopotâmia e a Grécia é tema de vivos debates ainda hoje. Uma hipótese que me parece razoável é que os fenícios tenham sido os intermediários entre as duas terras (SCHIAPARELLI, 1925, p. 95). Um dos problemas não resolvidos relativamente à transmissão de conhecimentos é o de como Hiparco teve acesso às observações babilônicas, que tratarei em outra oportunidade.
} 
Como vimos, a maioria dos povos antigos observava os céus tendo em vista fins práticos: a determinação das melhores épocas para colheitas e caças, e a elaboração de calendários. Essas observações não eram, em geral, registradas. Os babilônios foram os primeiros a registrar sistematicamente o que viam nos céus, a ponto de se tornarem famosos na Antiguidade pela extensão dos dados astronômicos que produziram. Eles não utilizaram, ao que parece, nenhum outro instrumento além do gnômon, uma barra vertical cuja sombra indica a altura e a direção do Sol (COUPRIE, 2011, p. 21). Simplício, ao escrever no século VI EC um comentário sobre Os Céus, de Aristóteles, afirma que os gregos só passaram a entender os fenômenos celestes após o Filósofo ordenar que se buscasse os registros babilônicos, que cobririam um período de mais de 31.000 anos (EVANS, 1998, p. 312). Ainda que essa história reflita mais o imaginário acerca dos babilônios do que a verdade, as observações deles tiveram um papel fundamental no desenvolvimento da astronomia antiga. Os registros mais antigos datam do século XVI AEC, e mostram os primeiros e últimos nascimentos e ocasos de Vênus. As observações feitas a partir do reinado de Nabonassar (747-733 AEC) serão usadas séculos depois pelos astrônomos gregos como dados para suas teorias. Essas observações eram feitas utilizando um sistema de referência baseado nas constelações do zodíaco e dado em graus e minutos. Um exemplo disso é dado num texto de 568 AEC: "oitava noite, ao anoitecer, o deus Sin (a Lua) encontrava-se $6^{\circ} 18^{\prime}$ sob a Balança [Libra] do norte" (OLMSTEAD, 1938, p. 120).

Mas por que, afinal, os babilônios registravam as posições dos corpos celestes? EVANS (1998, p. 298) menciona dois fatores que explicariam a prática: em primeiro lugar, os babilônios interessavam-se pelas posições dos planetas $^{39}$ a fim de produzirem vaticínios para o rei e a nação. Para isso, observavam os sinais do céu, que eram registrados e utilizados para a previsão do destino, feita por

[...] experts com treinamento astronômico [...] [que], junto com os especialistas em encantamento (asipu), eram responsáveis pela interpretação dos sinais estelares, que sempre tinham de ser considerados em conexão com os sinais terrestres, nunca isoladamente [...]. $\mathrm{O}$ perigo previsto num evento astral poderia ser evitado através dos rituais apropriados. A morte do rei, por exemplo, pressagiada por um eclipse lunar ou um terremoto, poderia ser prevenida através do ritual do "rei substituto" (MAUL, 2007, p. 365).

\footnotetext{
${ }^{39} \mathrm{Na}$ astronomia antiga, entende-se por planeta os astros visíveis a olho nu que executavam, além do movimento diário, de leste a oeste, um movimento de oeste a leste (com retrogradações temporárias, nos casos de Mercúrio, Vênus, Marte, Júpiter e Saturno) ao longo do zodíaco. Portanto, o Sol e a Lua eram considerados planetas, juntamente com os outros cinco astros.
} 
Essa era a astrologia judicial, diferente da astrologia genealógica, que se baseia na posição dos astros no momento do nascimento da pessoa para a criação de horóscopos individuais, e que é um avanço helenístico (NEUGEBAUER, 1983, p. 39). Em segundo lugar, o trabalho de registrar as posições dos corpos celestes era facilitado pela estrutura política centralizada de longa data da Mesopotâmia, que permitia a criação de um lugar social na sociedade babilônica: aquele do escriba responsável por registrar diariamente as observações celestes. A partir do século VII AEC, essas observações são coletadas em "diários astronômicos", que cobriam períodos de seis ou sete meses e nos quais se anotavam uma grande quantidade de dados, como:

[...] o número de dias do mês precedente, o tempo entre o nascer da Lua e o pôr do Sol no último dia do mês em que a Lua nasce antes do pôr do Sol, os tempos entre o nascer do Sol e o da Lua no dia seguinte [ao do evento anterior], o tempo entre o pôr da Lua e o nascer do Sol no último dia em que a Lua se põe antes do Sol nascer, o tempo entre o nascer do Sol e o pôr da Lua no dia seguinte [ao do evento anterior], o tempo entre o nascer da Lua e o nascer do Sol no último dia em que a Lua está visível [...], a longitude de cada planeta (isto é, os signos do zodíaco em que eles estão situados), o nível do rio na Babilônia, e o preço da cevada, da tâmara, do sésamo, etc. (THURSTON, 1994, p. 68-9).

Esse tipo de registro continuou sendo feito até aproximadamente 50 AEC (SACHS, 1974, p. 44).

Para a produção desses registros, os babilônios usaram um sistema numérico de base 60, e para a escrita desses números (e também para as palavras) utilizavam o estilo, que era pressionado em tabletes de barro. Isso permitia que os registros fossem feitos com maior agilidade, já que bastava ao escriba pressionar o estilo, em vez de traçar sinais mais contínuos (EvAns, 1998, p. 12). Além disso, a notação matemática usada pelos babilônios era posicional, isto é, cada sinal tinha um valor dependendo do lugar que ocupava. Isso permitiu que a astronomia encontrasse terreno fértil na Babilônia, e entre as vantagens desse tipo de notação estão (OSSENDRIJVER, 2012, p. 18): (i) o uso de um número limitado de signos para representar qualquer número (sendo que, graficamente, três tipos de sinais eram usados: um vertical, um horizontal e outro inclinado, todos feitos com o estilo); (ii) as computações procediam com maior eficiência devido à uniformidade no tratamento dos números; (iii) a notação posicional, junto com o sistema sexagesimal, permite a representação de um grande número de fracões, que outros sistemas, como o decimal, não permitem - por exemplo: 1/3 pode ser representado no sistema sexagesimal como $0 ; 20$, mas como $0,333 \ldots$ no decimal. 
A disponibilidade de registros sistemáticos de observações celestes permitiu que os babilônios pudessem prever fenômenos como os eclipses lunares e solares (com mais sucesso para os primeiros). De fato, a ligação entre observação e predição é praticamente onipresente nos registros mesopotâmicos. RochBerg-HALton (1991, p. 119) afirma que, entre os textos babilônicos, "nenhum dos gêneros caracterizados como observacionais aparece como apenas um registro de fenômenos observados. Praticamente todos contêm predições [...]". Uma das motivações para as previsões era a já mencionada prática da astrologia judicial. Os primeiros registros de predições de eclipses aparecem no século VII AEC, nas correspondências entre os escribas-astrólogos e o rei. Nelas, aparecem previsões de eclipses lunares baseados numa regra simples: eclipses podem ocorrer a cada 5 ou 6 meses lunares ${ }^{40}$, e eclipses solares acontecem meio mês antes ou depois de um eclipse lunar (STEELE, 2000, p. 421-2 e idem, 2008, p. 735). O caráter dessas previsões é, no entanto, precário, pois ainda não se podia prever exatamente o dia do eclipse, ou mesmo dar certeza de que o fenômeno realmente ocorreria. Ainda que eclipses solares tenham sido previstos utilizando a regra simples acima, são os eclipses lunares e seus ciclos que estão na base dessas previsões. Posteriormente, métodos matemáticos mais sofisticados serão adotados pelos babilônios a partir do acúmulo de observações, o que permite que se adotem ciclos maiores. Por isso, creio que se pode considerar a previsão de eclipses lunares distintamente daqueles solares. O avanço predição de eclipses lunares pode ser considerado um efeito da prática de registrar os fenômenos celestes.

Os egípcios e os babilônios tinham uma cosmologia diversa daquela dos gregos. Se, como veremos adiante, os últimos acreditavam na esfericidade da Terra e do Universo, os primeiros adotavam uma cosmologia diferente. Para os egípcios, o Universo dividia-se em três partes: (i) a Terra plana, dividida pelo Nilo e circundada pelo oceano; (ii) o céu; e (iii) a região abaixo da Terra, lugar de tudo o que não se podia ver: os mortos, o Sol durante a noite e a Lua durante o dia (KRAGH, 2007, p. 7). A cosmologia dos babilônios era semelhante à dos egípcios. O mundo podia também ser dividido em três partes: Terra, céu, e um submundo dos mortos. Ainda que os registros antigos não mencionem exatamente a forma da Terra, supõe-se que os babilônios acreditassem que ela era plana, tal como em outras cosmologias antigas (ibidem, p. 9). Esse aspecto da cosmologia babilônica despertou a estupefação em alguns historiadores da astronomia, que viam um descompasso entre o alto grau de sofisticação da astronomia matemática desenvolvida na Mesopotâmia e a aparente crueza de uma cosmologia

\footnotetext{
${ }^{40}$ Os babilônios utilizavam um calendário luni-solar, em que os meses tinham 29 ou 30 dias.
} 
baseada em mitos e numaTerra plana, sendo que era possível dar argumentos empíricos a favor da forma esférica da Terra, tal como a sombra da Terra na Lua durante um eclipse lunar mencionada, entre outros, por Aristóteles ${ }^{41}$. De fato, parece haver nos babilônios uma independência entre uma teoria astronômica matemática capaz de fornecer previsões das posições dos planetas e um modelo geométrico do Universo, diversamente dos gregos, em que a geometria desempenhou papel fundamental no entendimento dos céus desde Eudoxo. Além dessas duas cosmologias (a egípcia e a babilônica), outras, como a hebreia, sustentavam o formato plano da Terra. Para os hebreus, a Terra era "uma superfície praticamente plana compreendendo os continentes e os mares" (SchiaPARELLI, 1925, p. 170). Podemos considerar a Terra plana como um tipo de "teoria rudimentar" - ainda que as cosmologias que afirmam esse formato da Terra sejam também uma cosmogonia religiosa (o que talvez fizesse com que fossem uma manifestação cultural). No entanto, seguimos a indicação de DREYER $(1953$, p. 8) de que o conhecimento possuído por esses povos acerca de um grande oceano que circundava a Terra apontava para o desenvolvimento concomitante do conhecimento geográfico. A Terra plana torna-se, assim, uma hipótese com algum indício empírico para os antigos.

Se a Terra era plana, qual seria a forma dos céus? Para os antigos egípcios, o céu era plano e sustentado por quatro pilares que representavam os pontos cardeais, sendo a maior extensão aquela que ia de norte a sul, pois era a mesma na qual o país se estendia; nele, as estrelas e os planetas eram carregados pelos deuses (DREYER, 1953, p. 3). Para os babilônios, os céus não se moviam, mas apenas os astros, que eram considerados seres vivos e associados aos deuses (tal como farão os gregos). Os hebreus, influenciados pelos babilônios, consideravam que o céu, ou firmamento, tinha um formato semiesférico (ScHIAPARELLI, 1925, p. 183). A ideia do céu como uma semiesfera aparece também em Hesíodo, para quem,

\footnotetext{
${ }^{41}$ Por exemplo, KRAGH, 2007, p. 9:

É bem sabido que as civilizações mesopotâmicas vieram a possuir uma sofisticada astronomia científica, muito mais desenvolvida do que aquela dos egípcios. Em face disso, é notável que a visão de mundo dos babilônios continuou mitológica e que a sua astronomia matemática não teve quase nenhum impacto sobre sua cosmologia.
}

Também PANNEKOEK, 1961, p. 65:

[Para os babilônios,] os fenômenos celestes não ocorriam em órbitas circulares num espaço tridimensional, mas numa abóbada [vault] bidimensional onde os luminares seguiam seu curso misterioso. Eles não desenvolveram estruturas geométricas do mundo; eles não eram pensadores filosóficos, mas sacerdotes, confinados nos ritos religiosos tradicionais e, portanto, não inclinados a adotar novas ideias cósmicas que não se conformassem com as doutrinas sagradas. 
além disso, "a profundidade do Tártaro [lugar onde os titãs estão aprisionados] é igual à altura dos céus" (DrEYER, 1925, p. 8). A Terra plana é o que divide as duas semiesferas. A consideração do céu como tendo formato semiesférico pode ser entendida como um tipo “teoria rudimentar" junto com a Terra plana circundada pelo grande oceano.

Não se sabe ao certo quando os planetas e seus movimentos foram identificados. Entre os egípcios, a primeira representação dos cinco planetas aparece na tumba do arquiteto real Senmut (c. 1473 AEC), embora certamente eles já fossem conhecidos bem anteriormente. Os egípcios chamavam Marte de "Hórus, o Vermelho" e o seu movimento retrógrado ${ }^{42}$ aparecia no epíteto "ele viaja para trás" (PARKER, 1974, p. 60). A mesma situação se dá entre os babilônios, entre os quais os planetas devem ter sido conhecidos anteriormente às suas representações como deuses em cilindros de selar do século XI AEC, aproximadamente. Por volta de $650 \mathrm{AEC}$, aparece um texto babilônico que será copiado até os tempos helenísticos: o MUL.APIN ${ }^{43}$. Entre outras informações astronômicas, como os nomes das estrelas e constelações, nele se menciona os movimentos dos planetas entre as estrelas. A observação contínua dos planetas e de seus movimentos permite que se tenha noção dos movimentos retrógrados, pois ora executavam um movimento em direção ao leste e ora ao oeste.

Foram essas mesmas observações sistemáticas que levaram os babilônios ao conhecimento de outros aspectos do movimento dos planetas: os seus ciclos no zodíaco com ocasionais retrogradações (exceto para o Sol e para a Lua). Os outros povos antigos que confeccionaram calendários tinham algum conhecimento da existência de um movimento cíclico dos astros, e era isso que permitia que eles criassem calendários baseados na Lua, no Sol ou no nascer de alguma estrela em certa época. Contudo, são os babilônios os primeiros a observar esses astros de modo sistemático e registrar suas posições. Vimos que os babilônios eram capazes de prever eclipses lunares a partir de uma regra que dizia que eles podem ocorrer a cada 5 ou 6 meses. O conhecimento dessa possibilidade e a disponibilidade de um amplo estoque de registros permitiram posteriormente aos babilônios o cálculo do ciclo da Lua, chamado $\operatorname{saros}^{44}$, um período de aproximadamente 18 anos, ao fim do qual a Lua retorna à mesma posição em relação à Terra e ao Sol. O saros torna-se conhecido no final do século

\footnotetext{
${ }^{42} \mathrm{O}$ movimento direto é o "movimento de oeste para leste através do céu (é oposto ao movimento diurno). Os planetas se deslocam em movimento direto na maior parte do tempo. O inverso denomina-se de movimento retrógrado" (MOURÃO, 1987, p. 552).

${ }^{43}$ Este nome é retirado das primeiras palavras do texto, e significa "A estrela do arado" (EvANs, 1998, p.5).

44 A palavra saros não aparece nos textos babilônicos. Uma história do termo pode ser encontrada em NeUGeBAuER, 1969, p. 141-3.
} 
VII AEC. Os períodos dos outros planetas também foram apurados a partir de observações. $\mathrm{Na}$ coleção de vaticínios chamada Enuma Anu Enlil, do final do segundo milênio AEC, observações de Vênus misturam-se a previsões sobre as próximas aparições do planeta (EvANS, 1998, p. 14). Ainda que haja discordância entre os historiadores a respeito da compreensão ou não, entre os babilônios, da identidade das aparições matinais e vespertinas de Mercúrio e Vênus, o certo é que o cálculo dos aparecimentos e desaparecimentos do último foi um dos primeiros a ser dominado na astronomia babilônica (VAN DER WAERDEN, 1951, p. 20). Os ciclos dos outros planetas, indicando a relação entre o número de retrogradações e a volta ao mesmo ponto do zodíaco (respectivamente, o período sinódico e o período tropical), vão aparecendo paulatinamente nos textos babilônicos. SCHIAPARELLI (1925, p. 114) menciona um texto de 523 AEC, em que aparecem efemérides perpétuas dos cinco planetas, contendo o número de anos e o número de períodos sinódicos:

- Para Júpiter: 71 ou 83 anos, 65 ou 76 períodos sinódicos;

- Para Vênus: 8 anos, 5 períodos sinódicos;

- Para Mercúrio: 46 anos, 145 períodos sinódicos;

- Para Saturno: 59 anos, 57 períodos sinódicos;

- Para Marte: 32, 47 ou 79 anos; 15, 22 ou 37 períodos sinódicos.

A origem desses ciclos é observacional e não pressupõe nenhum modelo do Universo. De posse de um estoque de diários astronômicos, os ciclos dos planetas "poderiam facilmente ter emergido após apenas um século de observação contínua" (EvANS, 1998, p. 315). Com eles em mãos, os babilônios podiam criar efemérides perpétuas, já que a cada novo ciclo se repetem os movimentos e as posições dos planetas. Esses ciclos são aproximados, entretanto, e correções sempre deveriam ser feitas. Por exemplo, tomemos o caso de Vênus: se considerarmos o período sinódico do planeta como sendo de 583,9213 dias, e o ano sideral de 365,2563 (os dados são de SCHIAPARELli, 1925, p. 113), teríamos, ao fim de 8 anos, 2922,05 dias, e ao fim de 5 períodos sinódicos, 2919,61 dias. A diferença, de dois dias e meio no início do segundo ciclo, aumentaria a cada novo ciclo, caso não fossem feitas as devidas correções. De fato, esse tipo de efeméride perpétua continuou sendo feito até o século I AEC.

O conhecimento dos ciclos planetários permite o surgimento de uma astronomia preditiva (ou com caráter preditivo mais acentuado). De posse de um registro das posições dos planetas, e sabendo-se qual são seus ciclos, é possível prever qual será a posição do planeta no futuro, bem como saber onde ele estava em algum tempo passado. Por exemplo, se quero saber a posição de Júpiter no ano de 2015, basta que eu veja as suas posições em 1943, 
usando o ciclo de 71 anos. Os textos que continham essas predições baseadas em ciclos foram chamados de textos ano-alvo ${ }^{45}$. A desvantagem desse método de predição é "a necessidade de compilar um conjunto completo de dados observacionais de um ciclo inteiro para cada planeta - até 83 anos no caso de Júpiter" (EvANS, 1998, p. 317). Esse tipo de prática mostra também uma diferença entre a astronomia dos babilônios e a dos gregos do século IV AEC, de Platão e Eudoxo: os primeiros estão interessados em predições das posições planetárias para, sobretudo, fins astrológicos; enquanto os últimos procuram criar modelos cosmológicos e geométricos, ausentes na Babilônia, e que, com maior ou menor sucesso, permitam uma explicação qualitativa dos movimentos celestes, sem, contudo, serem utilizáveis para a determinação e predição das posições dos astros.

$\mathrm{Na}$ Babilônia também se desenvolveu outra forma de predizer as posições dos planetas, que dispensa o grande volume de dados observacionais necessário para a predição baseada em ciclos planetários. Essa forma era baseada em procedimentos aritméticos e é encontrada em textos que vão do século III AEC ao século I EC. Havia duas variações: os chamados sistemas A e B (além de subvariações desses dois sistemas). O uso de procedimentos aritméticos é outra diferença em relação à astronomia grega, de caráter eminentemente geométrico ${ }^{46}$. Essa diferença é enfatizada por Neugebauer:

É um insight histórico de grande significação que a mais antiga astronomia matemática existente fosse governada por técnicas numéricas, e não por considerações geométricas, e, por outro lado, que o desenvolvimento de considerações geométricas não fosse, de modo algum, um passo "natural", tal como poderia parecer para nós que crescemos na tradição fundada pelos astrônomos gregos dos períodos helenístico e romano (NEUGEBAUER, 1975, p. 3).

Não deixa de ser interessante o fato de que aquilo que é considerado o auge da astronomia babilônica tenha florescido exatamente na época em que a Mesopotâmia iniciava seu lento declínio. Após a morte de Alexandre e a fundação do Império Selêucida, uma nova capital foi fundada: a cidade de Selêucia, que atraiu os oficiais e os comerciantes da Babilônia, deixando para trás apenas os sacerdotes dos templos e uma pequena população, numa cidade que estava "lentamente tornando-se uma vasta ruína" (GEORGE, 2007, p. 455).

\footnotetext{
45 Uma tradução literal da expressão inglêsa goal-year text, por sua vez traduzida literalmente do alemão Zieljahrtexte (THURSTON, 1994, p. 69).

46 Ainda que haja exceções, como a do astrônomo alexandrino do século II AEC Hipsicles, que utilizava progressões aritméticas para o cálculo do nascimento dos signos, e isso numa época em que Euclides já havia escrito seu opus magnum (do qual o chamado Décimo Quarto Livro foi escrito, justamente, por Hipsicles). No entanto, o método de Hipsicles é de origem babilônica. Sobre Hipsicles, ver EVANS, 1998, p. 121-5.
} 
Sabe-se que o período helenístico foi de intenso contato entre as culturas babilônica, egípcia e grega, e muito se fala sobre a influência da astronomia babilônica sobre a grega. No entanto, é plausível que os astrônomos babilônicos do período selêucida tivessem criado seus novos sistemas astronômicos a partir de influências gregas: para SCHIAPARELLI (1925, p. 114), neles já penetrara em parte "o espírito helênico". Essa influência explicaria a busca pelas leis que regem o movimento em longitude dos planetas na eclíptica com o uso quase exclusivamente de número, e não mais de séries de observações. Ademais, sabemos que os astrônomos babilônicos desse período sabiam o que era feito na Grécia - um exemplo é o astrônomo do século II AEC Seleuco, que defendia não apenas o formato esférico da Terra, mas também sua rotação e revolução em torno do Sol (como fizera Aristarco).

Além dos diários astronômicos, que, como vimos, continuaram a ser produzidos até a metade do século I AEC, outros dois tipos de textos passaram a ser escritos na Babilônia a partir do século III AEC: as efemérides e os textos de instrução. Os primeiros listavam os planetas e suas posições em alguns eventos, calculados a partir dos procedimentos presentes nos texto de instrução. Aqui, temos outra diferença da astronomia babilônica em relação à grega, que é a referência, nas efemérides, a eventos específicos do ciclo dos planetas: o início e fim das retrogradações, as oposições e as primeiras e últimas visibilidades no céu. Não se podia calcular prontamente a posição do planeta em qualquer tempo; caso se desejasse isso, devia-se fazer a interpolação entre os dados dos eventos das efemérides.

As efemérides mostram as datas e posições de eventos da Lua e dos cinco planetas, e não lidam diretamente com o Sol (ThURSTON, 1994, p. 71). No entanto, pode-se descobrir o que os astrônomos babilônios haviam descoberto a respeito do movimento solar a partir das efemérides lunares.

ThURSTON (ibidem) exemplifica uma típica efeméride lunar com o tablete ACT $13^{47}$, que indica a longitude da Lua quando cheia em cada mês. Nele, há quatro colunas: a primeira mostra o ano da efeméride, 195 da era selêucida (ou 116 AEC), indicado no sistema numérico sexagesimal $^{48}$; a segunda, os nomes babilônicos dos meses; a terceira, a longitude da Lua, indicada com numeração sexagesimal e signos do zodíaco:

\footnotetext{
47 A numeração dos tabletes astronômicos babilônicos segue a ordenação feita na catalogação de Otto Neugebauer, em seu Astronomical Cuneiform Texts (ACT).

48 A prática atual é separar os lugares sexagesimais com vírgulas, e a parte fracional do número com ponto e vírgula. Isso não constitui anacronismo, já que o uso do grau (ou ush, como os babilônios chamavam a unidade) para a mensuração de um céu dividido em $360^{\circ}$ é um avanço babilônico. Assim, 3,15 é igual a 3 x $60+15=195$. As longitudes expressas na numeração sexagesimal são usadas até hoje, e, assim, 9;7,30 gir pode ser entendido como $9^{\circ} 7^{\prime}$ 30" no signo de gir.
} 


\begin{tabular}{|c|c|c|}
\hline 3,15 & nisannu & $9 ; 7,30$ gir \\
\hline & ayaru & $7 ; 15 p a$ \\
\hline & simanu & $5 ; 22,30$ mash \\
\hline & $d u z u$ & $3 ; 30 g u$ \\
\hline & $a b u$ & $1 ; 37,30 \mathrm{zib}$ \\
\hline & ululu & $0 ; 52$ hun \\
\hline & tashritu & $0 ; 52 \mathrm{mul}$ \\
\hline & arahsamna & $0 ; 52$ mash \\
\hline & kislimu & $0 ; 52$ kushu \\
\hline & tebetu & $0 ; 52 a$ \\
\hline & sabatu & $0 ; 52$ absin \\
\hline & adaru & $0 ; 37,30$ rin \\
\hline 3,16 & nisannu & $28 ; 45 \mathrm{rin}$ \\
\hline
\end{tabular}

Como a efeméride indica a longitude da Lua cheia, sabemos que o Sol está em oposição em relação a ela, ou seja, a $180^{\circ}$ ou seis signos do zodíaco. Nos meses em que a Lua cheia ocorreu em 52' de alguns signos, sabemos que o Sol avançou um signo, ou $30^{\circ}$, por mês. Assim, entre os meses ululu e sabatu, podemos dizer que o Sol avança um signo por mês. Na maioria dos outros meses, o Sol avança $28^{\circ} 7^{\prime}$ '30", ou 15/16 de um signo por mês (por exemplo, entre ayaru e simanu: $5^{\circ} 22^{\prime} 30^{\prime \prime}+30^{\circ}-7^{\circ} 15^{\prime}=28^{\circ} 7^{\prime} 30^{\prime \prime}$ ). Entre os meses sabatu e adaru, e entre abu e ululu, a velocidade solar tem um valor intermediário entre esses dois valores. Isso quer dizer que os babilônios descobriram a chamada anomalia solar, que é a variação da velocidade do Sol durante o ano, em seu avanço pela eclíptica. Essa é a base do chamado sistema A: “[...] o sistema A assume uma descontinuidade da velocidade solar em dois pontos dados da eclíptica, com valores constantes nos outros lugares" (NEUGEBAUER, 1954, p. 64). Os babilônios descobriram a anomalia solar a partir da constatação da diferença de duração das estações, obtida através da mensuração dos solstícios e equinócios através do gnômon e com a ajuda do registro sistemático, provavelmente.

O sistema A era usado também para os outros cinco planetas. O princípio é o mesmo: a eclíptica é dividida em uma "zona rápida" e outra "devagar", e os eventos planetários - tais como início e fim das retrogradações, o primeiro nascimento helíaco (isto é, pouco antes do nascer do Sol) visível, o último ocaso helíaco (pouco depois do pôr do Sol) visível, e as oposições - são calculados, tanto a data quanto a longitude, a partir disso. Os babilônios 
sabiam que os eventos do ciclo sinódico ocorriam sempre na mesma elongação (a distância entre o Sol e o planeta, medida a partir da Terra). Assim, os acréscimos na longitude dos eventos, ou os arcos sinódicos (isto é, a diferença em graus entre dois eventos), serão constantes em cada uma das zonas da eclíptica, de acordo com a maior ou menor velocidade do Sol.

O outro sistema numérico utilizado pelos astrônomos babilônicos é o sistema B. Enquanto o sistema A se caracteriza pela divisão da eclíptica em zonas de velocidades diferentes, o sistema B funciona através de acréscimos iguais nos arcos sinódicos. Usado tanto para o Sol quanto para os outros planetas, esse método de computação era mais simples do que o sistema A, e tendia a ser mais preciso, porque, em vez de apenas dois arcos sinódicos fixos (ou mais, em casos de variações do sistema A), havia vários valores para esses arcos. $\mathrm{O}$ sistema B é considerado posterior ao sistema A, mas ambos continuaram sendo utilizados contemporaneamente. A preferência por um sistema ou outro na confecção das efemérides era determinada pela "conveniência, precisão requerida, ou preferência pessoal” (ibidem, p. 65).

A astronomia babilônica foi capaz de atacar o problema da anomalia solar, criando métodos numéricos sofisticados o suficiente para permitir a previsão das posições planetárias. Alcançado esse estágio, começa a declinar. Obviamente, isso não pode ser creditado apenas a razões "internas": o declínio político dos impérios Selêucida e Parta, bem como a ascensão de outros centros urbanos como Alexandria, contribuíram para a diminuição da prática astronômica na Babilônia. De fato, a ciência (ou como se queira chamar) é uma parte da civilização. Ainda que seus produtos possam ser conhecidos e desenvolvidos em outras culturas e línguas que não as de origem, ela está ligada a um tempo e a um lugar; a utilização e desenvolvimento dos saberes científicos que são transmitidos de uma cultura à outra envolve processos de seleção e adaptação ${ }^{49}$.

\section{A astronomia grega}

A tradição astronômica grega começa com Homero e Hesíodo. Em Homero, a Terra é representada como um disco e são feitas referências ao costume grego de se saber a época do ano a partir da visibilidade e momento do nascimento de uma estrela (as chamadas "fases das estrelas"). Esse costume também aparece n’Os trabalhos e os dias, de Hesíodo, em que as

\footnotetext{
${ }^{49}$ Sobre isso, ver JONES (1996).
} 
várias épocas do ano são descritas a partir das estrelas e constelações no céu, e a partir disso são feitas indicações sobre o tipo de trabalho agrícola a ser feito. Hesíodo é considerado o primeiro autor grego a postular a forma esférica do Universo, dividido em duas semiesferas pela superfície plana do disco que seria o formato da Terra (DrEYER, 1953, p. 8). Tal concepção da forma do Universo será importante no desenrolar da história da astronomia grega.

James Evans, em sua obra sobre a história da astronomia antiga, divide a astronomia grega a partir do século V AEC em três tradições: literária, filosófica e científica (EvANS, 1998, p. 17). A tradição literária compreende autores gregos como Arato, autor dos Fenômenos, em 275 AEC, e romanos, como Virgílio e Ovídio. Essa tradição continua o tipo de escrito astronômico de Hesíodo: calendários agrícolas baseados nas fases das estrelas.

Evans inclui na tradição filosófica autores como Demócrito, Platão e Aristóteles, cujas metafísicas serviriam de base para o trabalho dos astrônomos ditos "científicos", como Meton, Eudoxo e Aristarco. Ainda que essa distinção tripartite seja boa de um ponto de vista didático, para os propósitos desta dissertação tratarei conjuntamente da tradição filosófica e da tradição científica, dado que nem sempre é tão fácil distinguir uma da outra, principalmente nos primórdios das investigações celestes gregas. Além disso, estou interessado em avanços que causam outros avanços, e que, como tais, abrangem uma ampla gama de práticas (ver seção 1.1.3 do presente capítulo).

\subsection{Os pré-socráticos}

Tradicionalmente, considera-se que a tradição filosófico-científica da astronomia grega começa com Tales de Mileto (c. 625 - c. 547 AEC). Aristóteles o considera o fundador da corrente filosófica que buscava a arché, o princípio das coisas, em uma substância ou qualidade. $\mathrm{O}$ envolvimento de Tales com a astronomia é algo que Platão confirma, ao mencionar, em seu Teeteto, a anedota segundo a qual o grande sábio Tales teria sido zombado por uma jovem escrava trácia ao cair num poço enquanto observava as estrelas (ADORNO, 1991a, p. 3).

O feito astronômico de Tales mais lembrado foi a sua suposta previsão de um eclipse solar. A história é narrada por Heródoto, segundo a qual uma batalha entre medos e partas teria sido encerrada após o eclipse solar, visto como um sinal para o fim da luta. Heródoto 
menciona que Tales teria predito o ano do acontecimento desse eclipse, que se acredita, hoje, ter sido 585 AEC. Duvida-se, entretanto, da capacidade de Tales de prever eclipses solares ainda que os babilônios fossem capazes de prever eclipses lunares, e com base nesses, a possibilidade de eclipses solares, de forma que Tales poderia ter aprendido com os astrônomos da Babilônia. Neugebauer discorda dessa hipótese. Ele afirma que os babilônios não tinham na época uma teoria específica para eclipses solares, e, além disso, que jamais desenvolveram qualquer teoria que levasse em conta a latitude geográfica para a previsão dos eclipses (NEUGEBAUER, 1969, p. 142). Da mesma opinião, DREYER (1953, p. 12) considera

no mínimo muito estranho que nem Aristóteles nem outro autor astronômico da Antiguidade mencione essa predição, e, claramente, está fora de questão que Tales tenha sido capaz de prever quão extenso um eclipse do Sol seria para uma determinada localidade.

Ainda que Tales possa não ter previsto um eclipse solar, sabia explicá-los. O filósofo jônio afirmava que um eclipse do Sol ocorria quando a Lua se encontrava na sua frente. Da mesma forma, Tales também explicava os eclipses lunares: a Lua torna-se eclipsada quando passa pela sombra da Terra. Ele também ensinava que a Lua não tinha luz própria, mas que essa vinha do Sol (ibidem, p. 13). Não se sabe ao certo como Tales tinha conhecimento desses fatos. Sabe-se, porém, que Tales e outros astrônomos gregos utilizavam uma camera obscura

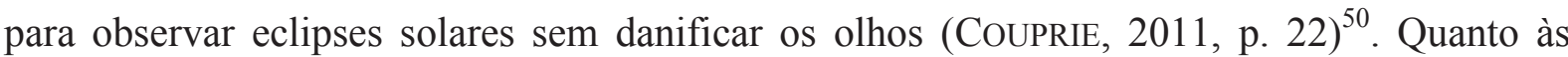
explicações de Tales terem uma possível origem babilônica, deve-se notar que os astrônomos babilônios sabiam predizer eclipses, especialmente os lunares, mas, em termos cosmogônicos ou cosmológicos, pouco produziram, até pelo tipo de astronomia que cultivavam - não um tipo de astronomia geométrica, mas numérica, que dispensaria explicações para os fenômenos que estavam interessados apenas em predizer. De resto, Tales acreditava que o formato da Terra era de um disco, tal como os babilônios. Seja como for, dentro da tradição astronômica grega, Tales inicia um "modo de encarar os problemas que constituiu a chamada pesquisa naturalística, essencialmente diversa de posições advinhas de outros ambientes" (ADORNO, 1991a, p. 8).

Conterrâneo e contemporâneo mais novo de Tales, Anaximandro de Mileto (nascido em c. 611 AEC) é considerado o primeiro filósofo a afirmar que a Terra se encontra no centro

\footnotetext{
${ }^{50}$ Como citei anteriormente, não se sabe se os babilônios utilizaram outro instrumento além do gnômon para suas observações. No entanto, supõe-se que protegiam os olhos durante a observação de um eclipse solar ao olhá-lo através da sua reflexão numa superfície líquida. Ver COUPRIE, 2011, p. 22.
} 
do Cosmos (Dreyer, 1953, p. 15). Para ele, a Terra não é um disco plano, mas tem um formato de tambor, sendo que um dos lados é habitado. A Terra está no centro do Universo e por isso não tem tendência a cair em nenhuma direção, permanecendo imóvel eternamente. Anaximandro também acreditava que as estrelas e os planetas eram furos em aros que circundavam a Terra, dos quais saía fogo. Cada estrela e planeta possuía seu próprio aro, e as fases e os eclipses da Lua, bem como os do Sol, eram explicados através da contração e expansão dos furos dos respectivos aros (HoCKEY, 2005, p. 44).

Anaximandro também tido como o introdutor do gnômon entre os gregos, e o teria utilizado para marcar as horas do dia e os solstícios e equinócios ${ }^{51}$. Os solstícios já eram mencionados por autores como Hesíodo, e chamados de tropai helioio, ou "viragem do Sol" (EvANS, 1998, p. 56). De fato, os solstícios eram percebidos a qualquer um que observasse o Sol se pôr a partir de, digamos, o início da primavera. Quem fizesse tal observação notaria que o Sol se coloca sempre mais a norte (no hemisfério norte) no horizonte, até chegar a um ponto máximo, e depois retornar. O que Anaximandro fez foi utilizar o gnômon para marcar os dias exatos dos solstícios e equinócios. Outro instrumento utilizado pelo filósofo foi a clepsidra, um relógio de água com duas vasilhas, uma mais alta que lança água lentamente numa outra mais baixa, e ele pode ter feito com ela a mensuração do diâmetro aparente do Sol, enchendo a vasilha superior com água desde o primeiro aparecimento do Sol no horizonte até o momento em que fosse visto completamente, e enchendo novamente essa vasilha quantas vezes fossem necessárias. Assim, teria chegado à conclusão de que a vasilha precisa ser cheia 720 vezes, o que daria ao Sol um diâmetro angular de $12^{0}$ (COUPRIE, 2011, p. 25).

Credita-se também a Anaximandro a mensuração da obliquidade da eclíptica. Os doxógrafos mencionam que o filósofo acreditava que o círculo do Sol era oblíquo, e seu uso do gnômon para a determinação dos solstícios e equinócios podem ter, de fato, o levado a conceber que o Sol se movia em um círculo inclinado em relação ao horizonte. EvANS (1998, p. 56) menciona, porém, que a atribuição dessa descoberta pode ser uma interpretação do doxógrafo.

Para KUHN (1957, p. 27), Anaximandro foi o primeiro a propor mecanismos conhecidos como explicações para eventos e fenômenos para os quais eram invocadas causas divinas. O uso do aro com fogo como o mecanismo que explicaria os astros e seus

\footnotetext{
${ }^{51}$ Ainda que seja provável que Tales já utilizasse o gnômon (sobre isso ver KIRK \& RAVEN, 1957, p. 115). Em geral, casos de atribuição de descobertas, uso e invenção de instrumentos e ideias filosóficas são ambíguos, e diferentes doxógrafos atribuem tais coisas a diferentes filósofos.
} 
movimentos é o primeiro passo na direção de um Universo mecânico que dispensaria a ação divina.

Pitágoras de Samos (c. 570 - c. 480 AEC) é, talvez, o melhor exemplo da inextricabilidade dos papéis de filósofo, cientista e místico entre os antigos gregos. Fundador de uma escola, ele ensinava que o Universo é um todo ordenado (com efeito, ele é o primeiro a usar a palavra kosmos para se referir a essa característica do mundo - ainda que Anaximandro também houvesse utilizado a palavra [HockeY, 2005, p. 940]). Aristóteles afirma que para Pitágoras todas as coisas eram números. Pitágoras é creditado como o primeiro astrônomo grego a reconhecer que Phosphorus e Hesperus, as estrelas da manhã e da tarde, eram o mesmo planeta, Vênus (DREYER, 1953, p. 38). Suas pesquisas matemáticas o levaram a descobrir as relações numéricas entre os intervalos musicais de oitava, quinta e quarta, e a partir disso, postular a existência de uma harmonia geral no mundo, e por consequência, uma harmonia das esferas: os movimentos dos astros produziriam sons que se relacionariam através das relações numéricas descobertas; assim, cada planeta produziria seu próprio som. A ideia da harmonia das esferas é o ponto de partida da tradição grega de salvar os fenômenos: por mais que os astros pareçam irregulares, por mais que seus movimentos pareçam complexos e aleatórios, principalmente no que se refere à retrogradação dos planetas, o mundo é feito de modo matemático, e cabe ao astrônomo descobrir a ordem e a simplicidade matemática subjacente à multiplicidade dos fenômenos.

Pitágoras influiu também para o surgimento de outra característica marcante da astronomia grega: seu caráter geométrico. Acredita-se que Pitágoras escondeu de seus discípulos a descoberta ${ }^{52}$ de que a diagonal do quadrado de lado 1 era um número irracional, dado que isso contradiria a crença pitagórica de que tudo era número (íntegro). Isso fez com que Platão, um admirador de Pitágoras, afirmasse que a construção do mundo tem base geométrica, e não aritmética, tal como para os pitagóricos (HockeY, 2005, p. 940) . Com Platão surge o preceito de que a astronomia deve ser feita com modelos que usam o círculo como base para a representação dos movimentos celestes.

Os autores antigos discordam sobre quem teria primeiro afirmado a forma esférica da Terra: Diógenes Laércio diz que teria sido Pitágoras, enquanto Teofrasto atribui tal afirmação a Parmênides (Zenão diz que teria sido Hesíodo) (DrEYER, 1953, p. 38). Dreyer diz que é possível que ambos, Pitágoras e Parmênides, tenham chegado a esse avanço, mas, enquanto o

\footnotetext{
${ }^{52}$ Ainda que não se saiba quem descobriu os números irracionais. Ver ADORNO, 1991a, p. 112 e HEATH, 1921, p. 155 .
} 
segundo o ensinava abertamente, Pitágoras e seus alunos mantinham o segredo típico dos conhecimentos mais elevados também para essa descoberta. Além disso, Pitágoras teria chegado à figura da esfera a partir de considerações filosóficas: tanto os céus quanto a Terra deveriam, por necessidade, ter a mesma forma (ibidem). Temos aqui o nascimento daquilo que Kuhn chama de "cosmologia científica” (KUHN, 1957, p. 25), baseada no que ele também chamou de Universo de duas esferas: "uma esfera interior para o homem, e uma esfera exterior para as estrelas" (ibidem, p. 27). Kuhn afirma que por mais que essa estrutura tenha variações através dos séculos, especialmente nos vários modelos que foram dados para os movimentos dos planetas, ela se manterá inquestionável até a Revolução Científica. Além das razões metafísicas e empíricas (como veremos adiante com Aristóteles) para a adoção dessa estrutura, haveria também razões estéticas: dado que as estrelas revolucionam eternamente, que figura seria melhor para representar seus movimentos do que a esfera, "cuja superfície é completamente simétrica e uma das poucas que podem girar eternamente sobre si mesmas, ocupando exatamente o mesmo espaço em cada instante de seu movimento" (ibidem, p. 28)?

Parmênides de Eléia (c. 515 - c. 450 AEC) ensinava que as aparências sensíveis eram enganadoras, e nisso se aproximava da escola pitagórica (considera-se que uma das influências de Parmênides seja o pitagórico Ameinias Diocaites [HoCKEY, 2005, p. 871]). Para ambas as correntes de pensamento, as aparências sensíveis não revelam diretamente a realidade, que, se para os pitagóricos pode ser alcançada através do estudo matemático do mundo, só podia ser alcançada, segundo Parmênides, através do uso puro e total da razão, entendida como lógica e em oposição aos sentidos. O filósofo levanta o problema de como a mudança seria possível e da possibilidade de um conhecimento do mundo tal qual se nos apresenta, porque o devir das coisas implica em contradição entre o que é e o que já não é, sendo que aquilo que é, o Ser, é, e não pode deixar de ser; os dados sensíveis levariam apenas a um conhecimento provável, opinião; enquanto o pensamento racional pode levar ao conhecimento da realidade:

A aceitação dos dados da experiência [...] implica multiplicidade e dispersão, contradição; a definição do indefinido implica o estilhaçamento do real em unidades opostas entre si, onde ao lado das coisas que são necessita-se colocar algo que não é. O pensamento, por sua vez, vê a si mesmo como discurso, mas como discurso que é unidade, onde cada membro singular do discurso se articula ao outro em uma continuidade que constitui e pressupõe o todo, compacto, que é a própria realidade (ADORNO, 1991a, p. 44). 
As considerações filosóficas de Parmênides incidem também sobre a cosmologia. Tal como em Pitágoras, para Parmênides o Universo é esférico, já que a esfera é a forma perfeita, por "ser igual a si mesma em todos os lados" (KIRK \& RAVEN, 1957, p. 276). Da mesma forma, o Universo deve ser finito, pois o infinito, o indeterminado, sequer pode ser pensado. Parmênides acreditava também que o Universo era formado por camadas concêntricas à Terra central, nas quais estavam as estrelas fixas e os planetas - ainda que tal conhecimento só pudesse ser considerado provável, por não derivar necessariamente dos princípios metafísicos do Ser. DREYER (1953, p. 21) considera esse episódio como sendo de grande significação na história da astronomia, por ser a primeira vez em que aparece a ideia de um Universo formado por círculos concêntricos.

A partir de Pitágoras e Parmênides, outros filósofos gregos trabalharam com o conceito de um Universo formado por duas esferas. Empédocles de Agrigento (c. 493 - c. 433 AEC) afirmava que a esfera das estrelas fixas era feita de ar condensado semelhante a cristal, dentro da qual os planetas moviam-se livremente (ibidem, 24). Acredita-se que ele considerava que os céus tinham a forma de um ovo, algo que SCHIAPARELLI $(1925$, p. 329) atribui ao "testemunho cotidiano da visão". O filósofo de Agrigento notou a inclinação dos polos dos céus em relação ao horizonte, e a explicou afirmando que era causada pelo rápido movimento do ar, movido por sua vez pelo movimento célere do Sol. Leucipo (c. 480 - c. 420 AEC) também procurou explicar a inclinação dos polos celestes. Para ele, a Terra plana ${ }^{53}$ teria afundado em direção ao sul, região aquecida pelo Sol e muito mais fluida do que o norte frio e congelado (DREYER, 1953, p. 27-8). Demócrito (c. 460 - 370 AEC), discipulo de Leucipo, subscreve a essa explicação.

No entanto, a maior contribuição de Leucipo e Demócrito foi a criação do atomismo. O atomismo era uma filosofia segundo a qual o Universo é composto de infinitas partículas que se movem no vácuo. $\mathrm{O}$ atomismo é uma tentativa de

[...] sustentar a tese do Ser Uno de Parmênides sem sacrificar o múltiplo e o movimento, estilhaçando [...] o Uno em infinitos átomos, cada um possuindo as características do Ser de Parmênides, diversos não por qualidade, mas por quantidade, de forma que era necessário admitir o vazio para explicar o juntar-se e o separar-se dos átomos dos quais advêm o nascer e o morrer das coisas (ADORNO, 1991a, p. 117).

\footnotetext{
${ }^{53}$ Em seu artigo sobre Leucipo em HocKEY, 2005 (p. 691-2), Kenneth Mayers sugere que possa haver lacunas nos textos restantes de Leucipo, de modo que o filósofo talvez não acreditasse numa Terra plana.
} 
O atomismo pretende ser uma explicação global da realidade, sendo aquilo a que poderíamos chamar de uma visão de mundo. De acordo com essa visão, os eventos do mundo físico (e, em certa medida, também os eventos da liberdade humana, de acordo com a interpretação epicurista do atomismo) são explicáveis a partir da junção e separação dos átomos. Tal visão é realista, no sentido de que os eventos do mundo físico ocorrem e podem ser explicados sem a menção à percepção do homem. De fato, as qualidades das coisas, tais como percebidas pelos homens, não estão nelas mesmas, mas são geradas pelo encontro dos átomos com outro apanhado de átomos, o homem. Leucipo ensinava que "nada ocorre por acaso" (KIRK \& RAVEN, 1957, p. 413), e Demócrito afirmava que "por convenção são o doce e o salgado, o quente e o frio, por convenção é a cor, na verdade há apenas átomos e vazios" (ibidem, p. 422). Essa é a distinção entre qualidades primárias e qualidades secundárias, que será retomada dois milênios depois por Galileu. Outro avanço do atomismo é a hipótese do Universo infinito; ora, num Universo infinito com infinitos átomos, deve haver, então, uma infinidade de mundos; da mesma forma, não haveria um centro, ou alguma parte mais privilegiada do que outra. Essa visão contrasta com aquela do Universo das duas esferas que assumiria a primazia nas obras dos filósofos e astrônomos a partir de Platão e Aristóteles.

Ainda que nenhuma obra de Demócrito tenha restado, Schiaparelli (1926, p. 256) afirma que é ele que primeiro distingue a astronomia da meteorologia. Até então, os sacerdotes-escribas babilônios e os filósofos gregos se interessavam por tudo que se passava nos céus - os primeiros, anotando os eventos meteorológicos e o clima em seus diários astronômicos; os segundos, procurando explicações para tudo que se passasse nos céus. Para o historiador e astrônomo italiano, a distinção operada por Demócrito pode ser percebida já nos títulos de duas obras do filósofo grego: Sobre as causas celestes e Sobre as causas atmosféricas.

Ainda que filósofos como Tales e Anaximandro tivessem suas próprias explicações para os eclipses, é Anaxágoras de Clazomenae (500 AEC - 428 AEC) que cria a primeira teoria compreensiva sobre a Lua. Para o filósofo, os eclipses da Lua são causados pela passagem dessa pela sombra da Terra (entretanto, por notar que os eclipses da Lua eram mais frequentes do que aqueles do Sol, Anaxágoras acreditava que os eclipses lunares também podiam ser causados por corpos invisíveis a partir da Terra [SCHIAPARELLI, 1925, p. 371]), e os eclipses solares ocorrem quando a Lua se interpõe entre o Sol e a Terra (EvANS, 1998, p. 46). Ele também explicou as fases da Lua, indicando que a sua luz vinha do Sol - fato esse que indica, 
segundo DREYER (1953, p. 32), que Anaxágoras acreditava que a Lua era esférica (ainda que cresse que a Terra fosse plana).

Anaxágoras foi o filósofo-astrônomo que tentou unificar pela primeira vez a física da Terra com aquela dos céus. Ele afirmava que os astros são de natureza terrestre, sendo que a Lua é composta de terra e fogo - a mistura entre esses elementos faria com que a Lua apresentasse montanhas e vales. Também afirmava que o Sol era uma pedra vermelha em chamas, e chegou mesmo a afirmar que o astro era maior do que aparecia, sendo "maior do que o Peloponeso" (EvANS, 1998, p. 46). Schiaparelli dá uma versão bastante plausível sobre como Anaxágoras teria chegado a essa conclusão:

Para que o Peloponeso aparecesse aos nossos olhos não mais largo do que o disco solar parece-nos ser, conviria afastar-se dele cerca de dezesseis milhas. Dezesseis milhas eram, portanto, na mente do filósofo de Clazomenae, uma distância comparável às medidas celestes (SCHIAPARELLI, 1925, p. 332).

Anaxágoras foi o primeiro a adotar uma ordenação dos sete planetas que seria utilizada posteriormente por Platão e Aristóteles: Lua, Sol, e os demais planetas (KIRK \& RAVEN, 1957, p. 391). Deve-se ter em mente que a ordem dos planetas é, mesmo após Ptolomeu e até o tempo de Copérnico, matéria de convenção, dado que o único critério para a ordenação deles era que quanto maior o tempo de revolução de um planeta do ponto de vista da Terra, maior a sua distância ${ }^{54}$.

Estas opiniões causaram o que pode parecer, hoje, o primeiro caso de disputa entre ciência e religião. Por afirmar que os astros eram compostos de matéria comum, e assim negar a sua natureza divina, Anaxágoras foi acusado de impiedade e levado a julgamento em Atenas. No entanto, tanto DrEYER (1953, p. 32) quanto Evans (1998, p. 46) concordam que as ideias astronômicas de Anaxágoras não eram a motivação da acusação de impiedade, por mais estranhas que parecessem a alguns; em vez disso, o filósofo teria sido acusado por setores políticos que queriam atacar a reputação do estadista Péricles, de quem Anaxágoras era amigo.

O atomismo de Leucipo e Demócrito era um concorrente do Universo de duas esferas. Outra concepção contrária a essa última é aquela defendida por um contemporâneo de

\footnotetext{
${ }^{54}$ Exceto para a Lua e para o Sol, cujas distâncias relativas podem ser mensuradas através do conhecimento das fases da Lua e dos eclipses, como veremos na seção 2.6.1 do capítulo 2. Talvez o caso mais exemplar do caráter convencional da ordenação dos planetas seja aquele de Mercúrio e Vênus, ora posicionados acima, ora abaixo do Sol (SCHIAPARELLI, 1925, p, 332-3).
} 
Demócrito e Anaxágoras, Filolau de Crotona (nascido em c. 460 AEC). Como outros pitagóricos, Filolau também acreditava que "todas as coisas que podem ser conhecidas contêm número; sem isso, nada pode ser pensado ou conhecido" (KIRK \& RAVEN, 1957, p. 310), e o Universo deveria ter sido construído de maneira ordenada. O grande avanço de Filolau em relação aos filósofos anteriores - ainda que seja possível que o avanço fosse antigo e viesse já dos primeiros pitagóricos - foi a sua concepção de que a Terra não está no centro do Cosmos, mas sim um fogo central, o "altar da natureza" (SCHIAPARELLI, 1925, p. 334). Assim era porque o centro do mundo deveria ser ocupado não pela Terra impura, mas pelo fogo, elemento mais nobre. Ao redor desse fogo central havia dez esferas, a mais distante sendo aquela das estrelas fixas, depois as esferas referentes aos sete planetas (pela ordem, a partir das estrelas fixas: Saturno, Júpiter, Marte, o Sol, Vênus, Mercúrio e a Lua), em seguida a Terra, e depois àquilo que Filolau chamava de Antichthon, a Antiterra. Da Terra não se podia ver o fogo central, uma vez que sua parte habitada estava sempre voltada para a parte oposta ao centro. Da mesma forma, a Antiterra não podia ser vista porque a face que é voltada para o nosso planeta é sempre aquela contrária ao fogo central. Nessa concepção, o Sol não teria luz própria, mas armazenaria tanto a luz do fogo central quanto aquela espalhada pelo Universo para iluminar a Terra.

A inclusão da Antiterra no sistema de Filolau não é uma hipótese ad hoc, uma vez que não existe apenas para completar o número perfeito para os pitagóricos, dez. Sua função é explicar um problema também notado por Anaxágoras, o de que parece ocorrer mais eclipses lunares do que eclipses solares. A Lua seria eclipsada, então, não apenas pela sombra da Terra, mas também pela sombra da Antiterra $^{55}$ (DREYER, 1953, p.47).

Uma objeção contra esse sistema era o da possibilidade da discrepância entre distâncias angulares das estrelas medidas em diferentes locais ou de uma desigualdade dos dias durante o equinócio ${ }^{56}$, objeção que os pitagóricos consideram válida também para sistemas astronômicos geocêntricos. Diz Aristóteles:

A circunstância, pois, de a Terra distar do centro por um inteiro semidiâmetro do círculo por ela descrito não impede, segundo os pitagóricos, que os fenômenos nos apareçam como se

\footnotetext{
${ }^{55}$ DREYER (1953, p. 47) escreve que os astrônomos pitagóricos posteriores a Filolau assumiram a existência de vários outros corpos não vistos a partir da Terra para explicar a ocorrência frequente de eclipses lunares, o que mostra que haviam abandonado o axioma dos dez planetas.

${ }^{56}$ Esses argumentos são usados por Ptolomeu contra a hipótese de que a Terra não esteja no centro do Universo. Ver o Livro I, 5 de PtOlOMeU (1984).
} 
estivéssemos no centro; porque alguma diferença sensível não aparece sequer na suposição de que o centro da Terra seja o centro do Universo e que nós estejamos longe desse centro metade do diâmetro terrestre (apud SCHIAPARELLI, 1925, p. 372).

Isso quer dizer que a distância da Terra em relação ao centro do Universo, o fogo central, era comparável à distância da superfície do planeta em relação ao seu centro, e, mais importante, desprezível em relação ao tamanho do $\operatorname{Cosmos}^{57}$.

\subsection{Platão}

Também influenciado pelas ideias pitagóricas, Platão (c. 428 - 348/7 AEC) desenvolveu concepções astronômicas que se tornaram fundamentais para a astronomia posterior a ele. Suas ideias astronômicas apresentam dificuldades para o intérprete, tanto pelo grande número de obras em que são expressas quanto pelo modo poético com que são comunicadas. A influência pitagórica aparece primeiramente na adoção, por parte de Platão, do modelo do Universo de duas esferas: ele afirma que a Terra está no centro do Cosmos pelas mesmas razões que Anaximandro, isto é, por não ter motivo para cair em nenhuma direção:

Estou convencido, antes de tudo, que se a Terra, que é esférica, for colocada no meio do Universo, não tem necessidade de ar para não cair, nem de nenhum outro meio desse gênero, dado que basta para sustentá-la a uniformidade do Universo, que é igual a si próprio em cada parte sua, e o equilíbrio da própria Terra. De fato, um corpo em equilíbrio posto num meio uniforme não se inclina nem muito nem pouco para nenhuma parte (PlATÃo, 1997a, p. 242-3 [Fédon, 108e-109a]).

Na República, Platão descreve um modelo mecânico do Universo em que oito rodas são designadas para as estrelas fixas e para os sete planetas, ligadas a um eixo que as mantêm em movimento (Platão, 1997b, p. 523-5 [República, 616c-617e]). A roda externa, a das estrelas fixas, é responsável pela rotação diária dos céus, enquanto as outras sete giram lentamente em sentido oposto, para que ocorram os movimentos dos planetas através da eclíptica. A ordem dos planetas que Platão adota é Lua, Sol, Vênus, Mercúrio, Marte, Júpiter

\footnotetext{
${ }^{57}$ Ptolomeu defende que o tamanho da Terra é desprezível em relação ao tamanho do Universo apontando justamente para o argumento dos pitagóricos: não há diferença perceptível nas observações astronômicas feitas em partes diferentes da Terra, o que indica que o planeta é um ponto se comparado aos céus. Ver o livro I, 6 de PTOLOMEU (1984).
} 
e Saturno (EvANS, 1998, p. 348), seguindo a ordem Lua, Sol e demais planetas de Anaxágoras.

O Timeu, o locus clássico da cosmologia platônica, contém a concepção de que o Universo é um ser dotado de alma criado pelo Demiurgo. Este junta duas faixas em X, e divide a faixa interna em sete círculos. A faixa externa é aquela do "movimento da natureza do mesmo" (PlATÃo, 1997b, p. 563 [Timeu, 36b-d]), o equador celeste com o movimento diário das estrelas fixas, enquanto a interna, oblíqua, é aquela do "movimento da natureza do diverso", que representa as órbitas dos sete planetas pelo zodíaco, e gira em sentido contrário à primeira faixa. Assim, os sete planetas orbitariam no mesmo plano, inclinado em relação ao equador. A Terra permanece imóvel no centro, em volta do eixo do Universo (ibidem, p. 569 [ibidem, 40c] $)^{58}$. Além disso, Platão reconhece apenas um movimento para o mundo, aquele circular ao redor do eixo do Universo, e "mais cedo ou mais tarde todos os movimentos celestes devem ser reconduzidos à rotação da esfera estelar" (HANSON, 1973, p. 38).

Mais ainda do que os aspectos cosmológicos, talvez a maior contribuição de Platão para a astronomia seja um problema que ele deixou para os outros astrônomos. Tradicionalmente, acredita-se que Platão tenha proposto aos outros astrônomos que representassem o movimento irregular dos planetas através de movimentos circulares uniformes. Diz Simplício: "Platão colocou este problema para aqueles engajados nesses estudos (i.e., astronômicos): quais movimentos uniformes e ordenados devem ser hipotetizados para salvar os movimentos fenomênicos das estrelas errantes?" (apud VLASTOS, 2005, p. 60). As razões para a colocação desse problema são ao menos duas: em primeiro lugar, o pitagorismo de Platão, que supunha que os movimentos circulares eram mais nobres que os outros; em segundo lugar, uma razão ética, segundo a qual os movimentos celestes deveriam ser uniformes para espelhar o comportamento do homem sábio, do filósofo, que se mantém constante em suas decisões e nos rumos que dá à sua vida (HOCKEY, 2005, p. 914). PANNEKOEK (1961, p. 102) atribui essa proposição de Platão ao declínio do prestígio dos trabalhos manuais e práticos na sociedade cada vez mais escravocrata da Grécia Antiga. Ao contrário dos babilônios e dos filósofos gregos anteriores, Platão estava interessado não em procurar a representação, a explicação e os constituintes dos fenômenos do mundo do dia-adia, e por consequência, dos movimentos dos astros tais quais aparecem aos homens; mas em

\footnotetext{
${ }^{58}$ Segundo Aristóteles, Platão ensinava o movimento de rotação da Terra. O passo do Timeu em questão (40c) suscitou um vivo debate que durou por séculos, da Antiguidade até o século XX, motivado por questões filológicas. Sobre isso, ver DREYER, 1953, p. 71-84. Hoje, concorda-se em geral que a rotação da Terra contradiria inteiramente o resto do sistema platônico.
} 
procurar uma ordem subjacente, inacessível e baseada na teoria, na contemplação, antes da experiência sensível do homem comum. Ainda que essa atitude apareça já no misticismo pitagórico, com Platão ela se eleva ao estatuto de uma verdadeira teoria do conhecimento: o mundo real é o das ideias, não o dos sentidos.

Ainda assim, não se pode dizer que Platão fosse completamente avesso às vicissitudes do mundo sensível e dos movimentos fenomênicos dos céus. Em várias partes da sua obra, Platão mostra que conhecia pontos como a inclinação da eclíptica e o movimento retrógrado dos planetas. Para que pudesse encontrar a ordem subjacente aos fenômenos, era necessário prestar atenção aos movimentos visíveis dos astros, por mais enganadora que fosse a percepção sensível. Gregory Vlastos resume bem a posição filosófica de Platão acerca da relação observação-teoria em sua prática astronômica:

[O] rebaixamento do valor da experiência sensível poderia facilmente ter tornado Platão contrário à metodologia que transformou o estudo dos céus de conjecturas inspiradas em pesquisa controlada empiricamente. [...] Sua prática, se não sua teoria, mostra que ele poderia ter entendido a loucura de qualquer teorização sobre os céus que ignorasse ou negasse fatos averiguados por observação. Sua tarefa era, então, a de reconciliar as convicções a priori de que todos os movimentos são circulares com os fatos empíricos concernentes ao movimento "errante" das sete estrelas. No Timeu, o vemos projetando uma teoria designada a efetivar essa reconciliação: ele hipotetiza que os movimentos do Sol, Lua e planetas são em todos os casos composições de movimentos circulares não-errantes [unwandering] ocorrendo em diferentes direções em velocidades diferentes - o movimento para oeste do Mesmo no plano do equador celeste, composto com o movimento muito mais lento para o leste do Diferente, no ou perto do plano da eclíptica (VLASTOS, 2005, p. 53-4).

Vlastos (ibidem, p. 61-5) também chama atenção para outro aspecto do Cosmos platônico: tal como o Universo dos atomistas, aquele platônico também é guiado por leis naturais; o que muda é o fundamento dessas leis. Enquanto os primeiros afirmam que tudo no mundo ocorre por causa do movimento dos átomos no vácuo e dos seus choques e enganchamentos, criando um mundo baseado em leis naturais que não pressupõe divindades, o segundo ensina que o Universo divino criado pelo Demiurgo não será afetado em seu funcionamento - também ele está sujeito a leis naturais, cujo fundamento é o intelecto de uma divindade sem inveja de sua criação. Para Vlastos, a revolução que levou à ciência moderna é nada mais do que a "dissolução do modelo platônico do Cosmos" (ibidem, p. 62). O que determinou a longa vida e o sucesso do modelo platônico foi o seu caráter cinemático, em oposição à busca dinâmica das causas dos movimentos celestes por parte dos atomistas - um objetivo que a ciência antiga não poderia alcançar com os meios que dispunha, e que só 
poderia ser plenamente atingido através da unificação teórica e empírica da física terrestre e celeste e da criação de ferramentas matemáticas novas, avanços realizados nos séculos da Revolução Científica. O astrônomo platônico poderia simplesmente adotar o modelo das duas esferas baseado na metafísica das Ideias e tirar daí conclusões, sem ter que se preocupar com as causas dos fenômenos ${ }^{59}$. E foi esse o caminho adotado pela astronomia posterior, percorrido por "Eudoxo, Apolônio, Hiparco, Ptolomeu” (ibidem, p. 65).

\subsection{Eudoxo}

Eudoxo de Cnido (c. 390 - c. 338 AEC) foi o primeiro astrônomo grego a tentar resolver o problema proposto por Platão (SCHIAPARELLI, 1926, p. 95). Foi ele o primeiro a criar um modelo geométrico de todo o Universo, procurando representar o conhecimento astronômico então possuído. Eudoxo visitou Atenas e assistiu às aulas na Academia por dois meses (HoCKEY, 2005, p. 345). O sistema que ele propôs adota o modelo de duas esferas, com a Terra no centro, circundada pela esfera das estrelas fixas ${ }^{60}$. Em seu sistema, cada um dos sete planetas tem sua própria maquinaria de esferas concêntricas que são ajustadas, tanto no ângulo entre si quanto na velocidade de rotação, para representar os movimentos dos astros

\footnotetext{
${ }^{59}$ Isso não implica que os astrônomos gregos eram exclusivamente instrumentalistas. Pessoalmente, acredito que eram, em geral, realistas e concordo com Evans quando ele afirma que os gregos "seriam um povo muito estranho se tivessem desenvolvido modelos bem-sucedidos do movimento planetário e então se recusado a acreditar que esses modelos tivessem alguma coisa a ver com a natureza das coisas" (EvANS, 1998, p. 219). A astronomia não podia decidir, apenas pelas observações, questões que então só podiam ser decididas pela filosofia - o que não quer dizer que essas questões não tivessem importância para o astrônomo. Além disso, considerando-se a orientação pitagórico-platônica de boa parte da astronomia grega, a busca pela ordem dos céus através de movimentos circulares não era uma busca por um mero artifício que ajudasse a imaginação e permitisse ao astrônomo acalmar sua mente perante algo que lhe era inalcançável; essa busca era pela própria realidade, por algo mais real que as aparências sensíveis.

A orientação realista da astronomia grega pode ser vista também na investigação empírica de consequências dedutíveis das teorias. Por exemplo, Ptolomeu tentou medir a variação do diâmetro angular do Sol, algo que deveria ocorrer segundo o modelo solar de Hiparco (em que o Sol ora está mais próximo, ora mais distante da Terra). Sobre isso, ver EvANS, 1998, p. 216-219.

Uma visão alternativa acerca do debate instrumentalismo/realismo na astronomia grega é oferecida por Hetherington, 1996. Segundo o autor, os astrônomos gregos (especialmente Platão e Eudoxo) não podem ser bem classificados nem dentro da categoria "realistas", nem da categoria "instrumentalistas": "O sistema de Eudoxo para salvar os fenômenos é mais do que um dispositivo de cálculo, mas é menos empírico do que a realidade dos realistas" (ibidem, p. 274).

60 SChiAparelli (1926, p. 38-42) discute a tese segundo a qual Eudoxo teria trazido do Egito seus conhecimentos astronômicos e a ideia de um modelo mecânico concêntrico para o Universo. O historiador não vê razões nem para negar nem para afirmar a tese, mas afirma que "uma intervenção de ideias estrangeiras [aos gregos] não parece necessária", já que o modelo de Eudoxo "se conecta ao progresso precedente dos gregos nas ideias sobre a estrutura do mundo" (ibidem, p. 41).
} 
errantes. Além disso, dentro do sistema o movimento de cada planeta é independente de todos os demais. Sua solução (i) indicou o tipo de teoria planetária a ser buscada por astrônomos posteriores, ao utilizar geometria e parâmetros numéricos (ainda que em Eudoxo a teoria não busque fazer predições de posições planetárias), e (ii) traçou os padrões para o desenvolvimento da cosmologia grega a ele posterior, sobretudo em Aristóteles (EvANS, 1998, p. 306).

O conhecimento que se tem hoje sobre o sistema de Eudoxo se deve, sobretudo, à reconstrução feita por SCHIAPARELLI (2006, p. 5-112), baseada nos relatos de Aristóteles (em Metafísica XII, 8) e de Simplício (em seu comentário de Sobre os Céus, de Aristóteles). Ainda que o texto de Simplício seja mais extenso, a preferência é dada para aquele de Aristóteles, já que Simplício comete alguns erros e se baseia em fontes não disponíveis atualmente (sua fonte é uma obra desconhecida de Sosígenes, que por sua vez se baseia na perdida História da Astronomia de Eudemo, um contemporâneo de Aristóteles). O trecho em que Aristóteles discorre acerca de Eudoxo é o seguinte:

Eudoxo supôs que o Sol e a Lua fossem movidos cada um por três esferas, das quais a primeira é aquela que se move ao modo das estrelas fixas, a segunda se move segundo o círculo que passa pelo meio dos signos zodiacais, a terceira segundo um círculo colocado obliquamente na largura da zona zodiacal. Destes círculos oblíquos, aquele segundo o qual se move a Lua é inclinado em maior latitude do que aquele em que se move o Sol. E diz que os planetas são carregados cada um por quatro esferas, das quais a primeira e a segunda são as mesmas que para o Sol e a Lua, porque aquela das estrelas fixas pertence a todos, e aquela que lhe sucede e produz o movimento através do zodíaco é comum a todos. E [diz] que os polos da terceira [esfera] são, em todos [os planetas], colocados no círculo mediano dos signos, e que o movimento da quarta [esfera] se faz segundo um círculo oblíquo em relação ao meio [i.e., do equador] da precedente. E [diz] que os polos da terceira esfera são diferentes para alguns planetas, mas idênticos para Afrodite [Vênus] e Hermes [Mercúrio] (ARISTÓTELES apud SCHIAPARELLI, 1926, p. 94).

Tratarei, primeiro, da teoria solar e lunar de Eudoxo, e, em seguida, da sua teoria dos planetas.

\subsubsection{A teoria solar e lunar de Eudoxo}

O texto de Aristóteles diz que Eudoxo assumia três esferas para o Sol e para a Lua: uma para representar o movimento das estrelas fixas, outra para o movimento através do 
zodíaco, e uma terceira oblíqua à segunda. A figura 6 é uma representação simplificada do modelo de esferas concêntricas para a Lua. Como o modelo é geocêntrico, a Terra (que não é mostrada na figura) é um ponto no centro das esferas. A esfera 1 é a das estrelas fixas, e sua função é representar o movimento diário dos céus. Ela se move em direção ao oeste em um dia, nos polos $\mathrm{P}$ e Q. A esfera 2 é colocada dentro da esfera 1 com um ângulo que é igual à obliquidade da eclíptica (cerca de $24^{\circ}$ ). Essa esfera gira ao redor do eixo $\mathrm{AB}$ em aproximadamente 1 mês, em direção ao leste, no sentido contrário à esfera 1 . Sua função é representar o movimento mensal da Lua (marcada com a letra $\mathrm{M}$, na figura) através da eclíptica (ou, no caso do Sol, o movimento anual, o que faz com que a esfera 2 do modelo solar faça uma revolução completa em um ano).

A cada revolução diária da esfera 1, a Lua vai do leste ao oeste, nasce e se põe, para um observador na Terra. A esfera 2 gera um pequeno movimento por dia em sentido contrário, de forma que a Lua nasce e se põe em pontos diferentes do zodíaco através do mês. No caso do Sol, a esfera 2 faz com que o astro também nasça e se ponha em diferentes pontos da eclíptica, com a diferença que o período tropical é de 1 ano.

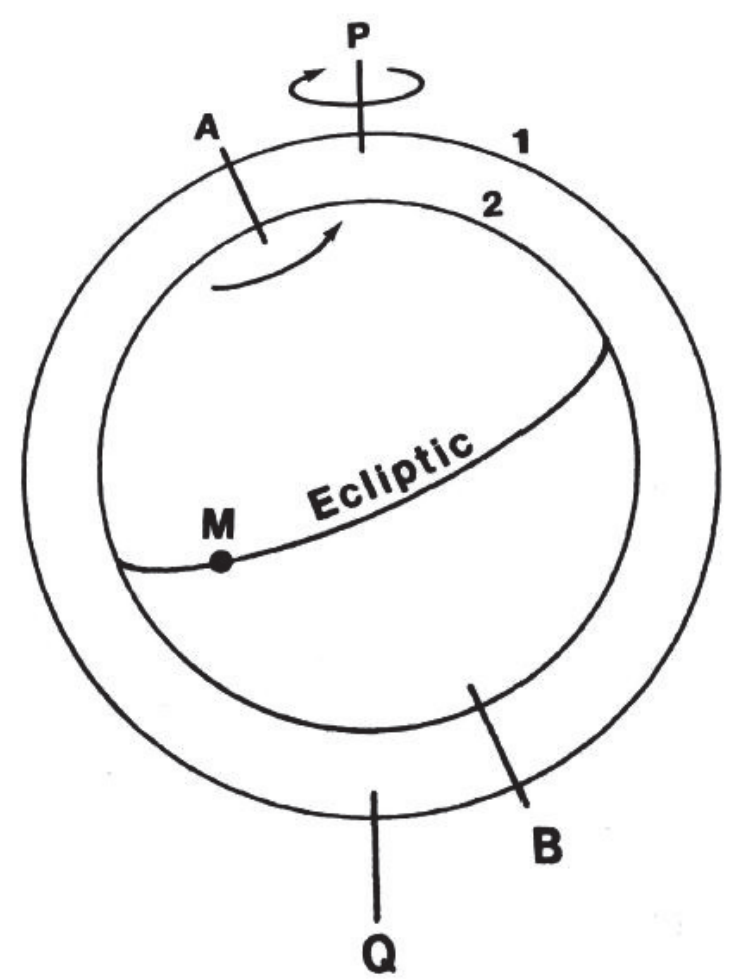

Figura 6. Representação simplificada do sistema de Eudoxo para o movimento da Lua (Fonte: EVANS, 1998, p. 307). 
O modelo do Sol e da Lua se completa com a terceira esfera, colocada dentro da esfera 2. No caso da Lua, sua função é representar o movimento da Lua em latitude, isto é, acima e abaixo da eclíptica. É esse movimento, de cerca de $5^{\circ}$, que explica porque não ocorrem eclipses lunares a cada Lua cheia: ora, se a Lua sempre se encontrasse na eclíptica, seria eclipsada pela sombra da Terra durante a Lua nova. O que ocorre é que os pontos em que a Lua passa pelo plano da eclíptica, também chamados de nodos, movem-se em direção ao oeste e completam uma revolução a cada 18,6 anos. Eclipses ocorrem quando a Lua se encontra num nodo e sua posição em relação ao Sol e a Terra geram uma Lua cheia. Na figura 7, essa terceira esfera, de número 2 , é inserida entre a esfera 1 e 3 , e sua função é marcar esse desvio da Lua em relação à eclíptica ${ }^{61}$. O ângulo entre $\mathrm{P}$ e $\mathrm{A}$ é igual à obliquidade da eclíptica, e o ângulo entre A e C é de $5^{\circ}$. A esfera 2 se move em direção ao oeste a cada 18,6 anos. Assim, a esfera 1 é responsável pelo movimento diário da Lua; a esfera 2, pela retrogradação dos nodos na eclíptica; e a esfera 3 pelo movimento mensal da Lua através do zodíaco.

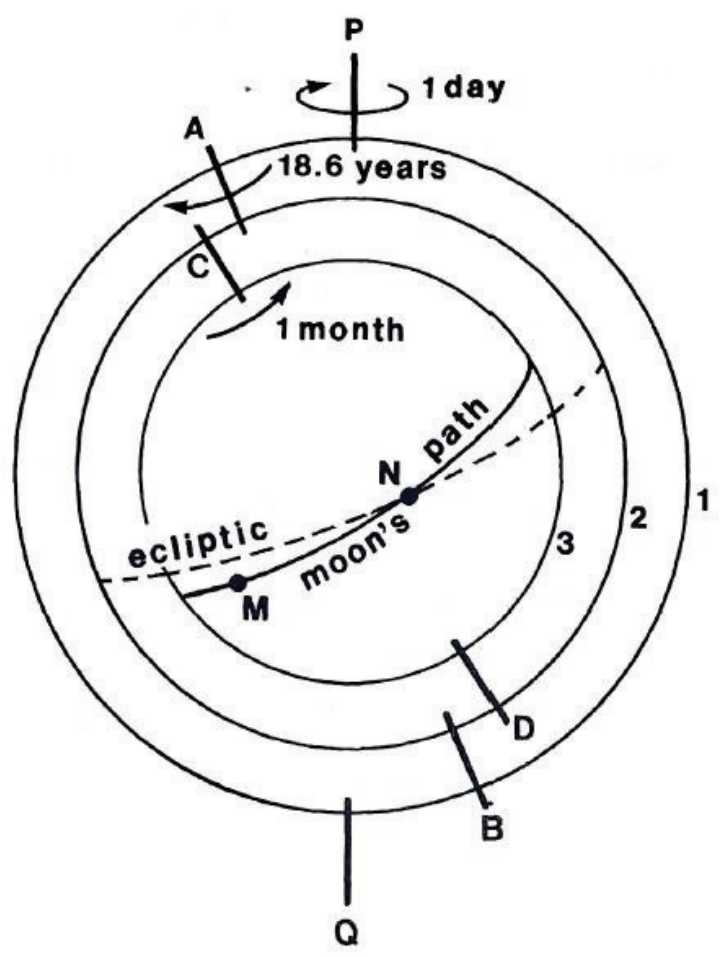

Figura 7. O sistema completo de Eudoxo para a Lua (Fonte: EVANS, 1998, p. 307).

\footnotetext{
${ }^{61}$ Simplício erra nesse ponto, fazendo com que a esfera responsável pelo movimento dos nodos seja a mais interna (SCHIAPARELLI, 1926, p. 21).
} 
O modelo de Eudoxo é capaz de representar bem três tipos de movimentos da Lua: seu movimento diário, seu movimento em longitude pelo zodíaco e aquele em latitude. No caso do Sol, o sistema de Eudoxo apresenta dois problemas: em primeiro lugar, ele ignora (ou rejeita, segundo HANSON [1973, p. 52]), a descoberta da variação da velocidade orbital do Sol, feita por Meton (fl. c. 432 AEC) e Euctemon (idem).

Meton e Euctemon são considerados por Evans (1998, p. 20) como os iniciadores da tradição científica da astronomia grega. Ambos os astrônomos (e provavelmente outros, não mencionados, que trabalhavam juntos) utilizavam o gnômon para determinar as datas dos solstícios, e a observação de um solstício em 432 AEC na cidade de Atenas é a primeira observação grega de que se tem o registro. Eles são conhecidos como introdutores do chamado ciclo metônico: um modo de sincronizar meses lunares com anos solares, que provavelmente já era conhecido pelos babilônios (ibidem, p. 185-6). Seja como for, o ciclo de Meton se baseava na quase igualdade entre 235 meses lunares, com 6939 dias e 16,5 horas, e 19 anos solares, com 6939 dias e 14,5 horas (ou seja, uma diferença de apenas duas horas). Ora, 19 anos lunares têm 228 meses, o que faz com que para completar os 235 meses lunares que equivalem aos 19 anos solares seja necessário adicionar 7 meses; haveria, então, 12 anos com 12 meses lunares e 7 anos com 13 meses. Outro avanço dos dois foi a descoberta da anomalia solar, feita através da determinação da duração das estações ${ }^{62}$. Num papiro conhecido como "A arte de Eudoxo" registra-se que Euctemon teria dado as seguintes durações para as estações (em dias):

em $430 A E C^{63}$

Euctemon

Erro de Euctemon

\begin{tabular}{lcc}
\hline Primavera & 93 & $-1,23$ \\
\hline Verão & 90 & $-2,01$ \\
\hline Outono & 90 & $+1,48$ \\
\hline Inverno & 92 & $+1,50$
\end{tabular}

(SCHIAPARELLI, 1926, p. 83)

\footnotetext{
${ }^{62}$ Um avanço que os babilônios já tinham alcançado, muito provavelmente, visto que para se chegar à anomalia solar deve-se partir de observações de solstícios e equinócios.

${ }^{63}$ A duração das estações muda com o tempo, devido (utilizando a teoria geocêntrica) ao movimento do apogeu, descoberto por astronomos árabes na Idade Média.
} 
Tais observações ${ }^{64}$ mostrariam que a anomalia solar já era conhecida entre os gregos há quase $100 \operatorname{anos}^{65}$. Talvez Eudoxo tenha preferido ignorar esse fato, mantendo o Sol com velocidade orbital constante, para manter o movimento circular preconizado por Platão. Notese que Eudoxo também ignora (ou rejeita, seguindo a sugestão de Hanson) a variação da velocidade orbital da Lua, que pode se mover diariamente entre $11,7^{\circ}$ e $14,6^{\circ}$ (EVANS, 1998, p. 311).

Em segundo lugar, ao manter três esferas também para o Sol, Eudoxo estava admitindo o movimento do astro em latitude. O problema que se põe aqui é o de definição: se a eclíptica é o grande círculo no qual o Sol orbita, como ele poderia ter um movimento em latitude em relação a ela? NEUGEBAUER (1975, p. 629) afirma que os antigos pitagóricos, ao preferirem a especulação à observação, definiam a eclíptica como "o grande círculo que se desvia do equador por um ângulo que é exatamente a $15^{\mathrm{a}}$ parte da circunferência do círculo [i.e., 24ㅁ]". Sendo assim, medições descuidadas do nascer do Sol num solstício poderiam indicar que o Sol se afasta desse ângulo de um ano para o outro, e apontar para um movimento em latitude. De todo modo, Aristóteles afirma em seu texto que o movimento da Lua em latitude é maior do que o do Sol.

\subsubsection{A teoria planetária de Eudoxo}

Para os demais planetas, Eudoxo tinha de dar conta de três movimentos: o movimento diário, o movimento através da eclíptica e as retrogradações. Os dois primeiros movimentos são produzidos pelas duas esferas da figura 6: a primeira que gira de leste a oeste diariamente, e a segunda que gira para o leste, no período tropical do planeta. Os períodos usados por Eudoxo, e sua comparação com os valores aceitos atualmente são os seguintes:

\footnotetext{
${ }^{64}$ Neugebauer discorda que Euctemon tenha determinado a duração das estações com base em observações. Para ele, o astrônomo grego simplesmente dividiu o ano de 365 num padrão de 360+5. Assim, sempre que possível os meses teriam 30 dias, e 5 meses teriam 31 dias. Isso se reflete na duração das estações: todas têm, no mínimo, 90 dias, com os cinco dias restantes divididos em duas delas. Para Neugebauer, assim foi feito por uma questão de "conveniência aritmética" (NeUGEBAUER, 1975, p. 628).

${ }^{65}$ Entre 432 AEC e 345 AEC, data provável da publicação de Sobre as velocidades, obra em que Eudoxo descreve seu sistema (HOCKEY, 2005, p. 345).
} 


\begin{tabular}{llr}
\hline Mercúrio & 1 ano & - \\
\hline Vênus & 1 ano & - \\
\hline Marte & 2 anos & 1 ano e 322 dias \\
\hline Júpiter & 12 anos & 11 anos e 315 dias \\
\hline Saturno & 30 anos & 29 anos e 166 dias \\
& & (SCHIAPARELLI, 1926, p. 66)
\end{tabular}

Para produzir as retrogradações dos planetas, Eudoxo inseriu duas esferas dentro da esfera 2. Na figura 8, essas esferas são numeradas como 3 e 4. As duas esferas são inclinadas uma em relação à outra, e esse ângulo depende do planeta em questão. Ambas executam a rotação no período sinódico de cada planeta, e giram em sentido contrário. O planeta, representado na figura como "X", localiza-se no equador da esfera 4. Os valores dos períodos sinódicos utilizados para essas duas esferas são os seguintes:

\begin{tabular}{llc} 
& Eudoxo & Valores modernos \\
\hline Mercúrio & 110 dias & 116 dias \\
\hline Vênus & 570 dias & 584 dias \\
\hline Marte & 260 dias & 780 dias \\
\hline Júpiter & 390 dias & 399 dias \\
\hline Saturno & 390 dias & 378 dias \\
& & (SCHIAPARELLI, 1926, p. 66)
\end{tabular}




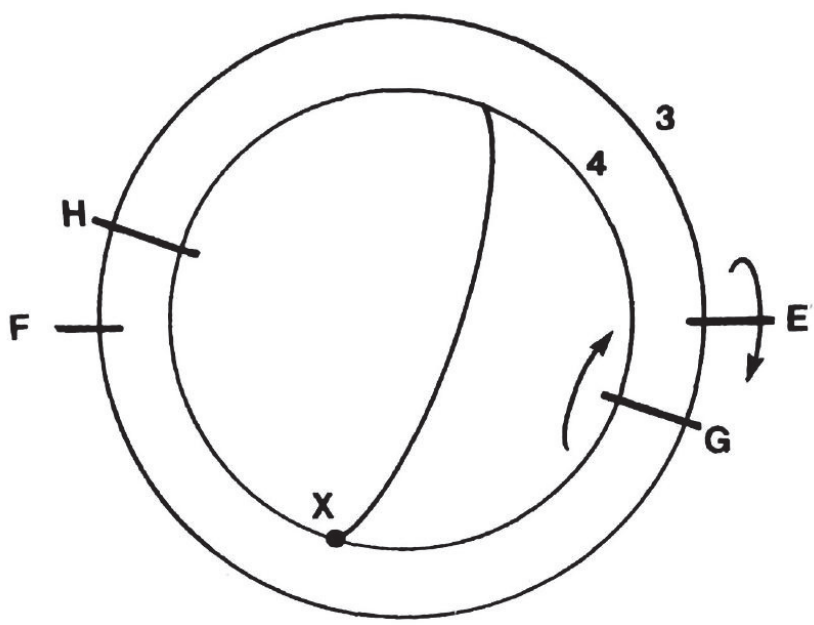

Figura 8. Esferas para a produção do movimento retrógrado dos planetas (Fonte: EVANS, 1998, p. 308).

As esferas da figura 8 são inseridas dentro da esfera 2 da figura 6, com os polos $\mathrm{E}$ e $\mathrm{F}$ da esfera 3 no equador da esfera 2, que é a eclíptica do sistema (ver a figura 9). Ao girar em sentido contrário, e por serem inclinadas uma em relação à outra, as esferas 3 e 4 fazem com que o ponto X trace uma figura, semelhante a um "8", chamada hipopédia (representada na figura 9 no meio da eclíptica). Essa figura, inserida no sistema, tem a função de representar a retrogradações do planeta.

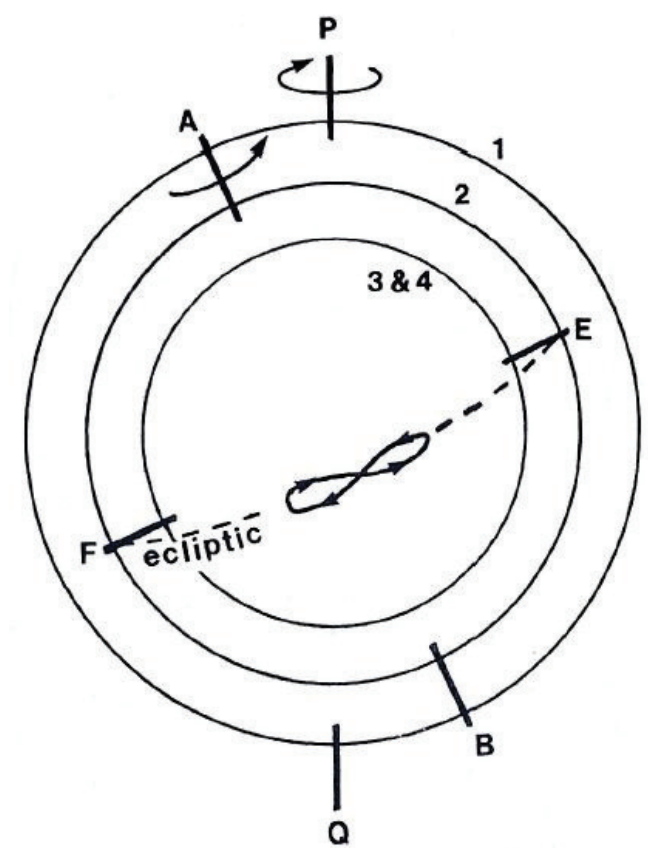

Figura 9. O modelo de Eudoxo para os movimentos de um planeta (Fonte: EVANS, 1998, p. 309). 
EVANS (1998, p. 308) aponta que a hipopédia tende a ser uma figura muito estreita: se o ângulo entre EF e GH na figura 8 for de $5^{\circ}$, a hipopédia terá um comprimento angular de $10^{\circ}$, e uma largura de $(2 / 10)^{\circ}$ nos lugares mais largos. Segundo ele (ibidem, p. 310), isso contradiria Simplício (a quem Schiaparelli segue), que afirma a intenção de Eudoxo de dar conta do movimento em latitude dos planetas. A razão disso está em que o sistema pode criar retrogradações tão estreitas que parecem se mover no plano da eclíptica, além do fato de que para dar conta do movimento em latitude, a hipopédia não seria adequada, já que o planeta alcançaria os limites norte e sul de latitude duas vezes a cada retrogradação, e não uma vez, como se observa.

O sistema representa bem, para Saturno, Júpiter e Mercúrio, três tipos de movimento: o movimento diário, o movimento na eclíptica e as retrogradações. Não funciona bem para Marte e Vênus. Evans (ibidem, p. 309) explica que a retrogradação produzida pelas esferas 3 e 4 só pode ocorrer se

\section{$\mathrm{T} \operatorname{sen} i>\mathrm{S}$,}

onde T é o período tropical do planeta, $i$ é o ângulo entre os eixos das esferas 3 e 4, e S é o período sinódico do planeta ${ }^{66}$. Para Marte e Vênus, S é maior que T, o que impossibilita a ocorrência de retrogradação. O autor conclui então que "é improvável que Eudoxo tenha dado valores para $i "$ (ibidem, p. 310).

Isso parece indicar que Eudoxo não buscava criar um sistema que fosse verdadeiro, mas sim um que fosse possível, que representasse os movimentos celestes suficientemente bem para as exigências da época. $O$ fato de que a explicação resultante não forme um sistema unificado e que explicasse fenômenos ainda desconhecidos por Eudoxo, tal como poderíamos esperar anacronicamente, não tem importância, já que, como afirma EvANS (1998, p. 312), "aquilo que contava como fenômeno em busca de explicação mudava conforme a astronomia grega amadurecia". De fato, as críticas mais fortes a Eudoxo não se devem a erros numéricos do modelo - nível de precisão não requerido na astronomia da época - mas à sua falha em explicar a mudança aparente do brilho dos planetas, já conhecida por Polemarco, discípulo de Eudoxo - e provavelmente tida por ele como uma falha sem importância, já que se manteve

\footnotetext{
${ }^{66}$ Utilizando os valores modernos para os parâmetros, já que há uma grande diferença entre o período sinódico de Marte tal como adotado por Eudoxo e o valor moderno. Schiaparelli testa duas hipóteses para a reconstrução da teoria de Marte: a de que o valor mencionado por Simplício esteja errado e a de que esteja certo. Em ambos os casos, "a teoria falha completamente na aplicação ao planeta Marte" (SCHIAPARELLI, 1926, p. 72).
} 
adepto das esferas concêntricas (SCHIAPARELLI, 1926, p. 110). A intenção de Eudoxo era a de criar uma explicação que fosse "fillosófica e geometricamente" (ibidem) satisfatória, e, ao responder ao desafio platônico, ele foi bem-sucedido nessa empresa. Segundo HANSON (1973, p. 58-9), Eudoxo se diferencia de duas formas dos astrônomos a ele anteriores: em primeiro lugar, em vez de apenas conjecturar acerca da existência de uma ordem universal, o astrônomo grego mostra como essa ordem poderia ser; em segundo lugar, Eudoxo analisa o problema em seus componentes básicos, procurando mostrar como o movimento global dos planetas pode ser investigado a partir de unidades menores, que por sua vez podem ser reduzidas a algum tipo de movimento ordenado, circular.

\subsubsection{As modificações do modelo de Eudoxo por Cálipo}

Como vimos, o modelo de Eudoxo apresentava alguns problemas, como a desconsideração da anomalia solar e lunar e o movimento latitudinal do Sol. Enquanto o segundo problema só seria resolvido por Hiparco, o primeiro foi enfrentado por um discípulo de Eudoxo, Cálipo (370 - 300 AEC). Simplício diz que Cálipo preferiu o modelo das esferas concêntricas de Eudoxo ao mais recente dos excêntricos, porque seguia a concepção de Aristóteles de que "todas as coisas celestes deveriam mover-se em torno do centro do mundo" (SIMPLício apud SchiaPARELLI, 1926, p. 100). Aristóteles diz que

Cálipo supôs a mesma disposição de esferas de Eudoxo, isto é, a mesma sucessão de distâncias das várias esferas de um mesmo astro, e atribuiu a Júpiter e a Saturno o mesmo número de esferas de Eudoxo; mas para o Sol e a Lua achou necessário acrescentar duas esferas a cada um para dar conta das aparências, e, para os planetas restantes, uma para cada um (ARISTÓTELES apud ibidem, p. 94).

Assim, Cálipo adicionou duas esferas para o Sol, duas para a Lua, uma para Mercúrio, uma para Vênus, e uma para Marte. A razão da inclusão de duas esferas para o Sol e a Lua é, segundo Simplício, dar conta da anomalia solar. Cálipo, seguindo a tradição de Meton e Euctemon, determinou a duração das estações ${ }^{67}$. Essas durações são (em dias):

\footnotetext{
${ }^{67}$ Diferentemente da sua opinião sobre a determinação da duração das estações por Euctemon, Neugebauer acredita que, dado que "estes valores [de Cálipo] combinam tão bem com os fatos, sua origem de observações dificilmente pode ser colocada em dúvida” (NEUGEBAUER, 1975, p.627).
} 


\begin{tabular}{lcc} 
Em 330 AEC & Cálipo & Erro de Cálipo \\
\hline Primavera & 94 & $-0,17$ \\
\hline Verão & 92 & $-0,08$ \\
\hline Outono & 89 & $+0,43$ \\
\hline Inverno & 90 & $-0,44$ \\
& & (SCHIAPARELLI, 1926, p. 83)
\end{tabular}

Não se sabe exatamente como Cálipo dispôs as duas esferas para o Sol e para a Lua. Da mesma forma, não se sabe nem os motivos e nem a disposição das esferas restantes adicionadas aos planetas Mercúrio, Vênus e Marte - Simplício diz apenas que Eudemo explica "clara e brevemente" (SIMPLício apud ibidem, p. 101) as razões dessas adições.

\subsection{Aristóteles}

Já Aristóteles (384 - 322 AEC) modifica o modelo eudoxiano para criar um sistema unificado do Universo. No entanto, antes de discorrer sobre essas modificações operadas por Aristóteles, creio ser útil tratar de alguns aspectos de sua cosmologia e astronomia.

Aristóteles é o primeiro filósofo grego a criar um sistema completo dos céus e da Terra, tratando de praticamente todos os ramos de conhecimento então estudados. Sua filosofia cria uma visão de mundo completa, que seria a base do conhecimento científico por quase dois milênios. Para o Filósofo, as coisas sensíveis são compostas por matéria (hýle) e forma (morphe) - dos nomes gregos, o nome da doutrina: hilemorfismo. Nisso, Aristóteles se distancia dos atomistas, que viam apenas os átomos, o elemento material, como causa de tudo o que é, e de Platão, que privilegiava as Formas em detrimento da matéria. Forma e matéria seriam, então, duas das quatro causas que determinam a mudança no mundo: tudo possui uma causa material, que é aquilo de que é feito; uma causa formal (que pode ser tanto a ideia, no caso da arte, ou a forma, no caso das coisas da natureza); uma causa eficiente (nas artes, o artífice; na natureza, as condições de existência ou acontecimento de algo); e uma causa final (que nas artes é a realização plena da ideia na matéria, e na natureza é realização plena da natureza, da essência, de algo). Ciência, para ele, era o conhecimento dos "princípios e causas que tornam possível o objeto [...], [ou seja, o conhecimento] daquilo que é, enquanto aquilo que é se determina mediante a forma e a matéria" (ADORNO, 1991b, p. 48). A scientia pode 
ser alcançada seja progredindo dos dados da experiência até se chegar às causas primeiras, seja através da dedução a partir dos primeiros princípios metafísicos (ibidem, p. 49).

No campo da astronomia, o Filósofo utiliza essas duas abordagens, e dá os contornos definitivos à ideia do Universo de duas esferas ao estabelecer quatro pontos que, ainda que tenham sido propostos anteriormente de uma ou outra forma, passarão a ser parte da visão de mundo de praticamente todos os outros astrônomos gregos posteriores. São eles (EvANS, 1998, p. 199): (i) a centralidade da Terra imóvel no Universo, (ii) a finitude do Universo, (iii) A imutabilidade da região supralunar, e (iv) a circularidade e uniformidade dos movimentos dos astros. Com essas doutrinas, Aristóteles cria um sistema cosmológico em que as esferas de Eudoxo se tornam um verdadeiro modelo cosmológico do mundo.

Adotando ideias de Empédocles de Agrigento de que "a região ocupada pelo homem é cheia de males, e de que esses se estendem até [a região da Lua]", enquanto a região acima da Lua é "muito mais pura" (DREYER, 1953, p. 25), Aristóteles distingue duas regiões no Universo: uma sublunar, e outra supralunar, com a primeira sendo a região da geração e corrupção, enquanto a outra é imutável. A região supralunar caracteriza-se pelo movimento circular dos corpos celestes, formados de éter, um elemento incorruptível que também forma as esferas que os carregam. Aristóteles afirma que o Universo é esférico, pois esse é o "formato mais apropriado para sua substância" (ARISTÓTELES, 2010, p. 74 [Sobre o céu, II, 4]). A fonte dos movimentos das esferas celestes é um primeiro motor imóvel, que "da circunferência estende seu poder para o centro" (DREYER, 1953, p. 110), diferentemente do fogo central dos pitagóricos que se localiza no centro.

Já na região sublunar, existem quatro elementos: terra, água, ar e fogo. Esses elementos estão sujeitos a dois tipos de movimento, natural e violento. Enquanto o último tipo de movimento é causado por uma força externa, o movimento natural dos elementos e seus compostos é aquele causado por uma tendência natural: a terra (e, em menor medida, a água) tende a se movimentar radialmente para o centro do Cosmos, enquanto o fogo (e, também em menor medida, o ar) tende a se afastar radialmente desse centro. Como o elemento terra tende a se movimentar localmente para o centro, o planeta Terra só pode estar no centro do Cosmos. Da mesma forma, por causa da tendência natural da terra de se dirigir para o centro do Universo, qualquer movimento da Terra, seja de rotação ou translação, teria de ser violento, e como tal não poderia durar. A Terra, então, é imóvel. (ARISTÓTELES, 2010, p. 73 [Sobre o céu, II, 14]). O formato da Terra, segundo Aristóteles, é esférico, pelo mesmo motivo de sua imobilidade, isto é, o fato de o elemento terra tender ao centro. É interessante notar que o 
argumento de Aristóteles para a imobilidade da Terra não é astronômico, mas físico; de fato, baseado apenas em observações, não é possível dizer se é a Terra que gira em seu próprio eixo, produzindo o movimento diário dos céus, ou se são os céus que se movimentam - tal questão só pode ser resolvida a partir do desenvolvimento de uma física que unifique o mundo sub e supralunar. Já em relação ao formato esférico da Terra, Aristóteles utiliza o argumento físico, mas também adiciona um argumento observacional: se a Terra não fosse esférica, "de que outra forma os eclipses da Lua poderiam mostrar segmentos da forma em que os vemos?" (ibidem, p. 74 [ibidem]).

Quanto à finitude do Universo, Aristóteles argumenta que se o Universo fosse infinito, as estrelas fixas, que se movem num círculo, deveriam realizar um deslocamento infinito em um tempo finito (HocKeY, 2005, p. 61). Aristóteles negava essa possibilidade, a ponto de negar a existência do vácuo, já que, para ele, a velocidade de um deslocamento varia de modo inversamente proporcional à densidade do meio e, assim, o vácuo permitiria o movimento instantâneo.

O terceiro ponto defendido por Aristóteles é o da imutabilidade dos céus. Assim é por causa da constituição das estrelas, dos planetas e das esferas que os carregam, todos de éter. Para o Filósofo, "os céus como um todo nem vieram a ser nem admitem destruição" (ARISTÓTEleS, 2010, p. 42 [Sobre o céu, II, 1]). A partir da imutabilidade da região supralunar, Aristóteles propõe sua quarta doutrina, a da circularidade e uniformidade dos movimentos celestes. Essas duas doutrinas, a da imutabilidade e da uniformidade dos movimentos circulares dos céus, são a base epistemológica e física para o trabalho do astrônomo. Aspectos sensíveis, como a luz e o calor do Sol e dos outros astros, que poderiam sugerir mudanças nos céus, seriam causados pela "fricção [dos astros] com o éter durante a revolução das esferas" (DREYER, 1953, p. 110), enquanto os cometas e a faixa da Via Láctea seriam apenas fenômenos meteorológicos que ocorrem na região sublunar.

Com essas quatro bases, Aristóteles transformou o modelo das esferas concêntricas de Eudoxo num verdadeiro sistema cosmológico. O modelo original funcionava para cada planeta, independentemente dos outros, e Aristóteles tenta unificar os movimentos de todos os planetas num único modelo concêntrico ${ }^{68}$. Ele percebeu que, se simplesmente pensasse o modelo de Eudoxo sem modificações, sobrepondo os modelos de cada planeta, o movimento dos planetas inferiores seria dependente do movimento daqueles superiores. Por exemplo, se inserirmos o sistema de esferas de Júpiter dentro do sistema de Saturno (isto é, se

\footnotetext{
${ }^{68}$ HANSON (1973, p. 65) afirma que Aristóteles queria um "Universo, não um Pluriverso".
} 
posicionarmos a esfera 1 - refiro-me à figura 9 acima - do planeta Júpiter dentro da esfera 4 de Saturno), o sistema de Júpiter irá ter seus movimentos afetados pelos movimentos do sistema de Saturno. Para conectar todos os sistemas, Aristóteles desenvolveu um esquema de esferas deferentes, ou reagentes, cuja função seria a de cancelar o movimento das esferas dos planetas superiores.

Vejamos como funciona o modelo de Aristóteles tomando como exemplo os planetas Saturno e Júpiter ${ }^{69}$. A esfera 4 de Saturno leva o planeta, e dentro dela é inserida uma esfera 4', que tem o mesmo eixo que a esfera 4, mas gira em sentido oposto. A esfera 4' irá, então, cancelar o movimento da esfera 4. Dentro da esfera 4', por sua vez, é colocada a esfera 3', que gira no mesmo eixo da esfera 3 , mas novamente em sentido contrário, para cancelar o movimento da esfera 3. Da mesma forma, dentro da esfera 3' é inserida a esfera 2', no mesmo eixo da esfera 2 e em sentido contrário a ela, também para cancelar o movimento da esfera 2. Já que os movimentos das esferas 4, 3 e 2 foram cancelados, a esfera 2' terá o mesmo movimento da esfera 1, girando uma vez por dia e podendo servir de receptáculo para o sistema de Júpiter, que também terá as esferas deferentes destinadas a cancelar seus movimentos e poder receber as esferas de Marte.

As modificações de Aristóteles foram feitas para criar um sistema "fisicamente plausível" (EVANS, 1998, p. 311), e não para melhorar a adequação empírica do modelo das esferas concêntricas, como é o caso das modificações de Cálipo. De fato, a principal falha do modelo, que é o fato de não dar conta da variação aparente do brilho dos planetas, não é enfrentada nem por Cálipo, nem por Aristóteles ${ }^{70}$. EvANS (ibidem) sugere que isso tem a ver com o modo como a astronomia era praticada na Grécia do século IV AEC: não como uma ciência preditiva, que deva dar conta de todos os aspectos empíricos disponíveis, mas como uma ciência puramente explicativa ${ }^{71}$. Já HANSON (1973, p. 87) afirma que os problemas empíricos da astronomia de Aristóteles não são necessariamente erros, mas estão ligados ao

\footnotetext{
${ }^{69}$ Para este passo, baseio-me na explicação presente em EVANS, 1998, p. 311.

${ }^{70}$ No entanto, Aristóteles parece duvidar das hipóteses dos astrônomos justamente pelo fato do brilho dos planetas não parecer constante, tal como menciona na obra perdida Problemas Físicos. Na Metafísica, XII, Aristóteles diz que "qual seja o número necessário [de movimentos celestes], deixaremos os mais doutos que nós dizerem” (ARISTÓTELES apud SCHIAPARELli, 1926, p. 111), o que pode indicar que o Filósofo não estava plenamente satisfeito com o modelo das esferas concêntricas, ainda que o tivesse usado como base de sua cosmologia.

${ }^{71}$ HANSON (1973, p. 85) considera que, até Newton, haveria duas tradições na astronomia, uma explicativa e outra preditiva. Enquanto a primeira se basearia em Aristóteles, a segunda teria como modelo a obra de Ptolomeu e utilizaria extensamente a matemática, e discussões sobre os méritos e deméritos de cada abordagem continuariam até que Newton propusesse uma teoria capaz tanto de predizer quanto de explicar.
} 
tipo de prática científica que ele adotou: mais do que gerar novos conjuntos de dados, a sua preocupação era "remodelar antigos fatos e teorias em novas estruturas científicas"; nesse sentido, Aristóteles seria um cientista do mesmo tipo de Copérnico e Newton.

\subsection{Heráclides de Heracléa}

A principal objeção contra o sistema das esferas concêntricas, já apontada quando do seu desenvolvimento por Eudoxo, foi o fato de não explicar a variação de brilho dos planetas. Essa variação é mais visível para os planetas Vênus e Marte. O último, por exemplo, pode ser o corpo celeste mais brilhante do céu noturno (excetuada a Lua, obviamente) em certas ocasiões (chegando a brilhar mais que a estrela Sirius), enquanto em outras épocas tem seu brilho bastante diminuído. Esse dado empírico foi responsável pelo abandono quase imediato do sistema de Eudoxo, obrigando os astrônomos a buscarem outras soluções para representar os movimentos do céu, ao mesmo tempo em que davam conta dessa variabilidade de brilho planetário.

Uma das primeiras tentativas de resolver esse problema foi proposta por Heráclides de Heracléa (c. 388 - c. 315 AEC), também conhecido como Heráclides Pôntico. SCHIAPARELLI (1927, p. 444) escreve que Heráclides havia conhecido todas as filosofias de seu tempo, a acadêmica (foi discípulo de Platão) e a peripatética (também foi discípulo de Aristóteles), sem se filiar a nenhuma escola, entretanto. Ele é considerado o primeiro $^{72}$ astrônomo grego a propor a rotação diária da Terra de oeste para leste, que poderia explicar a aparência do movimento dos céus, de leste para oeste.

A solução de Heráclides para o problema da variação do brilho dos planetas parte da constatação de que Vênus e Mercúrio nunca se afastam muito do Sol - ora são vistos após o pôr do Sol, ora antes do nascer do Sol. Isso, mais a variação do brilho de Vênus, poderia ter sugerido a Heráclides que o centro da órbita do último não fosse a Terra, mas algum outro ponto na direção do Sol. O centro dessa órbita, então, poderia ser um ponto sem nenhum corpo que o ocupasse, ou um astro: Heráclides prefere a segunda opção, já que "a ideia de assumir como centro [...] um simples ponto ideal sem qualquer entidade física deveria

\footnotetext{
${ }^{72}$ Cícero menciona Hiceto e Ecfanto de Siracusa (que provavelmente viveram no fim do século V AEC) como os primeiros proponentes da rotação da Terra. Como muito pouco se sabe dos dois, é possível que ambos sejam personagens de diálogos perdidos de Cícero. Ver HOCKEY, 2005, p. 486.
} 
parecer, à época, como ainda a nós pareceria, absurda" (SCHIAPARELLI, 1927, p. 444). O astrônomo adota, então, o Sol como centro da órbita de Vênus e de Mercúrio ${ }^{73}$, enquanto o Sol continua a orbitar a Terra, já não fixa, mas executando um movimento de rotação. Schiaparelli menciona que Heráclides teria expandido a ideia do movimento dos planetas ao redor do Sol também para Marte, Júpiter e Saturno, criando um sistema em que o Sol com os cinco planetas como satélites orbitavam ao redor da Terra:

Quem tenha sido o primeiro a estender [a ideia do movimento planetário ao redor do Sol] também aos três planetas superiores não fica claro a partir dos poucos escritos [de Heráclides] que temos. Apenas é certo que foi, se não o próprio Heráclides Pôntico, algum contemporâneo seu; e é certo ainda que Heráclides conheceu essa extensão; enfim, é mais que provável que ele a tenha adotado (SCHIAPARELLI, 1927, p. 448).

Uma das razões, além dos problemas físicos da mobilidade da Terra, pela qual as ideias de Heráclides não foram adotadas pelos astrônomos da Grécia antiga é o fato de que ele não quis ser um "chefe de escola" (ibidem, p. 450). Heráclides, pensador independente e - ao que se sabe - sem discípulos, não teria sido capaz de popularizar suas ideias a ponto de tornálas dominantes no panorama da astronomia grega. Há, também, uma questão de estilo de escrita científica: o modo de escrever de Heráclides não consistia em "exposição acurada, sustentada por provas geométricas" (ibidem). Caberia a outro astrônomo, cerca de meio século depois, a retomada da ideia de um sistema do mundo não aristotélico.

\subsection{Aristarco de Samos}

Aristarco de Samos (c. 310 - c. 230 AEC) é considerado o primeiro a propor a teoria heliocêntrica, ao expandir as ideias de Heráclides também para a Terra, colocada agora não mais como centro do Universo, mas como um planeta entre outros, girando ao redor do Sol. A teoria é descrita assim por Arquimedes no Contador de areia, escrito antes de 216 AEC:

Mas Aristarco lançou um livro consistindo de certas hipóteses, onde parece - como consequência das suposições feitas - que o Universo é muitas vezes maior do que o "universo" mencionado anteriormente. Suas hipóteses são de que as estrelas fixas e o Sol

\footnotetext{
${ }^{73}$ David Lindberg discorda disso, diferentemente de outros historiadores da astronomia, como Schiaparelli e Dreyer. Para Lindberg, a afirmação de que Heráclides ensinava que Mercúrio e Vênus orbitavam ao redor do Sol "não tem fundamentos" (LINDBERG, 2002, p. 135).
} 
quedam sem movimento, que a Terra revoluciona em torno do Sol em uma circunferência, que o Sol fica no centro da órbita, e que a esfera das estrelas fixas, situadas em torno do mesmo centro que o Sol, é tão grande que o círculo em que ele supõe que a Terra gira está para a distância das estrelas fixas na mesma proporção que o centro de uma esfera está para sua superfície (ARQUIMEDES apud HEATH, 1913, p. 302).

Outro relato da proposta de Aristarco aparece em texto de Plutarco de Queroneia (c. 46-120 EC), A face visível da Lua:

Só não movam contra mim, meus caros colegas, uma ação por impiedade ao estilo de Cleanto, que achou que era o dever dos gregos indiciar Aristarco de Samos, sob a acusação de impiedade, por colocar em movimento a lareira [centro] do Universo, resultado de sua tentativa de salvar os fenômenos ao supor que os céus permanecem em repouso e a Terra revoluciona em um círculo oblíquo, enquanto que ao mesmo tempo gira em torno de seu eixo (Plutarco apud HEATH, 1913, p. 304).

As teses de Aristarco lhe trouxeram problemas, e as críticas feitas ao astrônomo e ao seu sistema se basearam em alguns pontos:

- A ausência de paralaxe estelar anual: se a Terra se movesse ao redor do Sol, deveria haver diferença na posição relativa das estrelas durante o ano, conforme a Terra orbitasse $^{74}$. Este era o principal argumento contra o sistema heliocêntrico - que Aristarco procurou responder, ao afirmar que o raio das estrelas fixas era muito maior do que o raio da órbita da Terra (EvANs, 1998, p. 67);

- Aristarco (e também Heráclides) não criou uma nova física, mas adotou os ensinamentos aristotélicos. Para os cálculos das distâncias do Sol e da Lua, Aristarco adotou a concepção, baseada no modelo de Eudoxo e de Aristóteles, de que os astros se mantém a uma distância fixa da Terra. A física de Aristóteles não era adequada para um sistema astronômico em que a Terra se move, seja em rotação, seja em translação, já que o elemento terra deveria ter seu lugar natural no centro do Universo;

- O expediente matemático dos excêntricos e epiciclos, criados por Apolônio de Perga (c. 247 - c. 205 AEC) permitia explicar tudo que o sistema de Eudoxo explicava e também a variação do brilho dos planetas, sem, contudo, tirar da Terra a sua imobilidade, sendo mais plausível de acordo com a física da época e, portanto, preferível ao sistema heliocêntrico (SCHIAPARELLI, 1927, p. 453);

\footnotetext{
${ }^{74}$ Tal paralaxe só foi observada em 1836 (HOCKEY, 2005, p, 1042).
} 
- A popularização da astrologia nos tempos helenísticos tornava os astrônomos contrários a qualquer sistema que quebrasse a simetria dos sete planetas cujas posições relativas serviam de base para as previsões astrológicas. Ao colocar o Sol no centro e a Terra como um planeta, quebrava-se a base da crença dos eflúvios planetários, que era a diferença entre os céus portadores de algum tipo de poder e a Terra passiva (BARTON, 1994, passim). Alguns autores antigos chegaram a declarar dignos de maldição quem "perturbasse assim os princípios da astrologia" (SCHIAPARELLI, 1927, p. 454).

Tal como Heráclides, Aristarco não criou escola. Entre seus poucos discípulos está Seleuco de Selêucia ( $f l$. 150 AEC). Segundo a sugestão de Plutarco em suas Questões Platônicas, Aristarco teria tido uma atitude mais instrumentalista, ao passo que Seleuco teria interpretado o modelo heliocêntrico de maneira realista. Enquanto Aristarco afirmava que o Universo era muito maior do que se pensava, Seleuco acreditava que era infinito. Contra o argumento de que não havia evidências físicas para a rotação da Terra, Seleuco elaborou uma teoria das marés. Segundo Seleuco, as marés eram causadas pela rotação da Terra e pelo movimento orbital da Lua ao redor da Terra. O movimento da Lua faria com que o espírito vital que ocupa o espaço entre a Terra e a Lua fosse perturbado, contribuindo assim para o aparecimento das marés.

Aristarco também é mencionado como o inventor do escafo, uma versão do gnômon em que o plano é substituído por uma superfície côncava hemisférica (Fig. 10). O ponteiro vertical lança uma sombra sobre a superfície esférica, que está marcada com linhas, para melhor medir a posição angular do Sol (HEATH, 1913, p. 300).

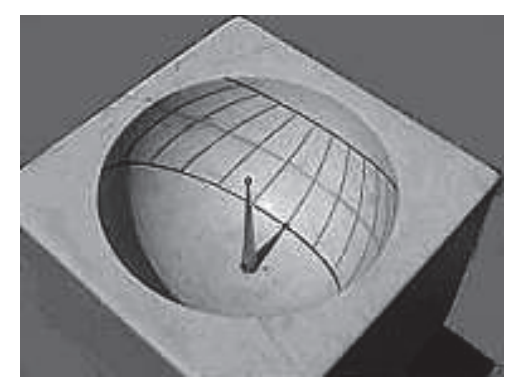

Figura 10. Escafo, versão gnômon inventado por Aristarco (fonte: internet). 


\subsubsection{O cálculo de Aristarco dos tamanhos e distâncias do Sol e da Lua}

Os filósofos e astrônomos gregos sempre tiveram a preocupação em determinar as distâncias dos astros em relação à Terra e seu tamanho, sem contudo fornecer qualquer expediente de demonstração geométrica ao modo de Eudoxo. Vimos, por exemplo, que Anaxágoras acreditava que o Sol tinha tamanho comparável ao do Peloponeso, e suas razões são puramente observacionais: ele baseou sua mensuração na identidade subjetiva entre o tamanho do Sol e do Peloponeso a certa distância. Parecia não haver nenhum fenômeno prontamente acessível que pudesse mostrar claramente, ou ao menos sugerir, o tamanho e distância dos astros. Para o caso do tamanho da Terra, a situação era diferente. Já o viajante que se movia em diferentes latitudes podia perceber mudanças no tempo de nascimento e ocaso das estrelas e dos planetas, e isso poderia lhe indicar a circunferência terrestre. Aristóteles menciona que os "matemáticos" estimavam a circunferência da Terra em 400.000 estádios (ver nota 45); não se sabe quem são esses matemáticos - ainda que frequentemente se proponha o nome de Eudoxo - nem o método utilizado (EvANS, 1998, p. 48).

A primeira demonstração geométrica do tamanho da Terra surge com Eratóstenes de Cirene (c. 274 - c. 194 AEC). Vivendo em Alexandria, ele baseou sua demonstração em duas assunções: (i) a Terra é uma esfera perfeita, e (ii) a distância do Sol em relação à Terra é grande o suficiente para que seus raios cheguem ao solo paralelamente (HoCKEY, 2005, p. 341). Considerando que as cidades antigas de Alexandria e Syene estavam no mesmo meridiano e distavam uma da outra em 5000 estádios $^{75}$, Eratóstenes utilizou o escafo para medir o ângulo da sombra em Alexandria no meio dia, que estimou ser a quinquagésima parte da circunferência, no dia e hora em que o Sol não deixasse sombra em um gnômon em Syene (ver figura 11).

\footnotetext{
${ }^{75}$ Não se sabe ao certo quanto vale um estádio em medidas modernas. Alguns sugerem que o estádio utilizado por Eratóstenes equivalia a 600 pés, que por sua vez variam de uma cidade para outra, enquanto outros, baseados em Plínio, afirmam que 40 estádios são iguais a um schoenus, uma unidade egípcia que era igual a $6,30 \mathrm{~km}$. De acordo com essas estimativas, um estádio seria igual a um valor entre $157,5 \mathrm{~m}$ e $185,5 \mathrm{~m}$. Sobre isso, ver HOCKEY, 2005, p. 342 e HEATH, 1913, p. 339.
} 


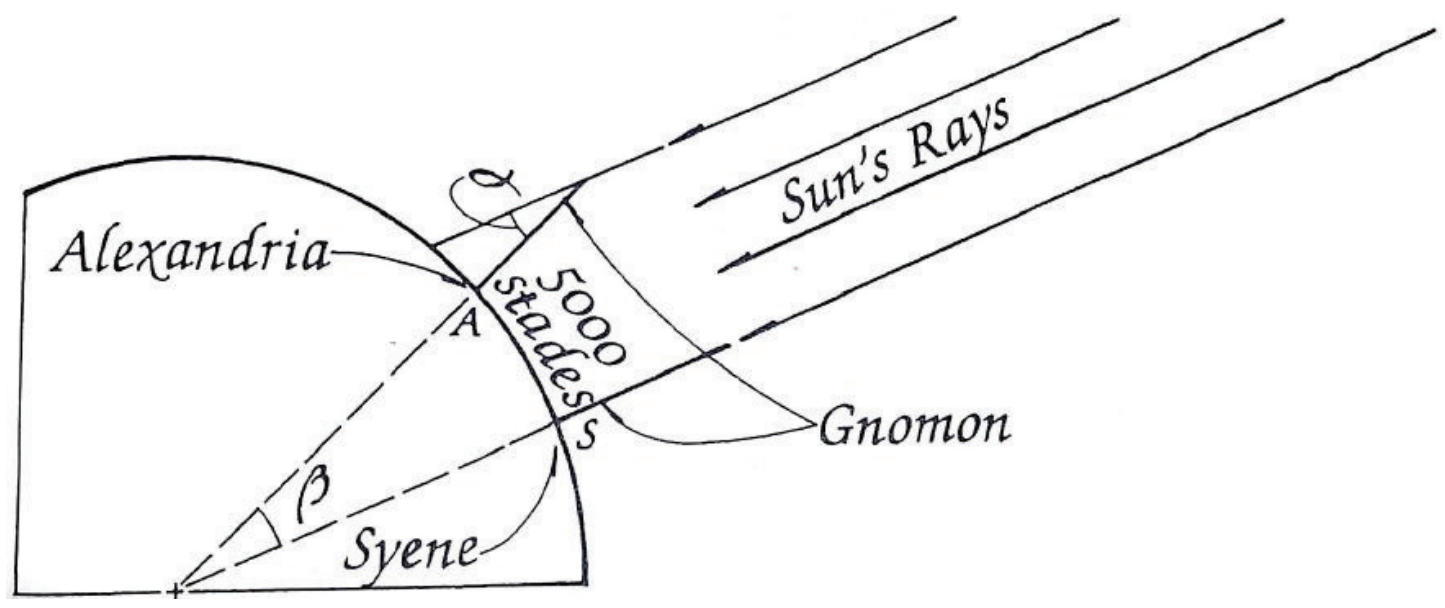

Figura 11. Mensuração do tamanho da Terra por

Eratóstenes (Fonte: VAN HELDEN, 1985, p. 5)

Na figura 11, o ângulo $\alpha$, da sombra em Alexandria é igual ao ângulo $\beta$, o ângulo entre as duas cidades com vértice no centro da terra. Como $\alpha=\beta$, e é igual a 1/50 da circunferência, o valor da circunferência da Terra é de 5000 x 50, ou 250.000 estádios. Um pequeno ajuste transformou o resultado em 252.000 estádios, de forma que cada grau da circunferência fosse igual a 700 estádios (VAN HeLden, 1985, p. 5).

Se Eratóstenes calculou o tamanho da Terra, coube a Aristarco calcular os tamanhos e distância de alguns corpos celestes. Isso é feito na única obra restante de Aristarco, Sobre os tamanhos e distâncias do Sol e da Lua, em que ele calcula a razão entre a distância Terra-Sol e a distância Terra-Lua, e também a razão entre os tamanhos do Sol e da Lua. O método utilizado é correto, apesar de ele utilizar dados imprecisos, que o levaram à conclusão que a distância do Sol é apenas 19 vezes a distância da Lua (o resultado correto seria em torno de 389 vezes). Para o cálculo, Aristarco baseia-se em seis hipóteses (HEATH, 1913, p. 353):

1. A Lua recebe sua luz do Sol;

2. A Terra está na relação de um ponto e centro para a esfera em que a Lua se move;

3. Quando a Lua aparece para nós dividida ao meio, o grande círculo que divide a parte escura da parte clara está na direção dos nossos olhos;

4. Quando a Lua aparece para nós dividida ao meio, sua distância para o Sol é menor que um quadrante [i.e., $90^{\circ}$ ] por $1 / 30$ de um quadrante [i.e., $87^{\circ}$ ];

5. A largura da sombra [da Terra] é [aquela] de duas Luas;

6. A Lua subentende a décima quinta parte de um signo do zodíaco [i.e., $2^{\circ}$ ]. 
A primeira conclusão de Aristarco se refere às razões das distâncias da Lua e Sol em relação à Terra. Na figura 12, a Lua é mostrada em uma das duas posições de seu ciclo em que é dividida ao meio (isso pode acontecer durante a Lua crescente ou minguante). De acordo com a hipótese 3, o ângulo SLT é de $90^{\circ}$. Ainda que Aristarco não utilize trigonometria - que será desenvolvida por Hiparco - e chegue aos seus resultados através de laboriosos procedimentos geométricos (ver HEATH, 1913, p. 351-414), podemos utilizar a trigonometria moderna para chegar mais facilmente aos resultados de Aristarco.

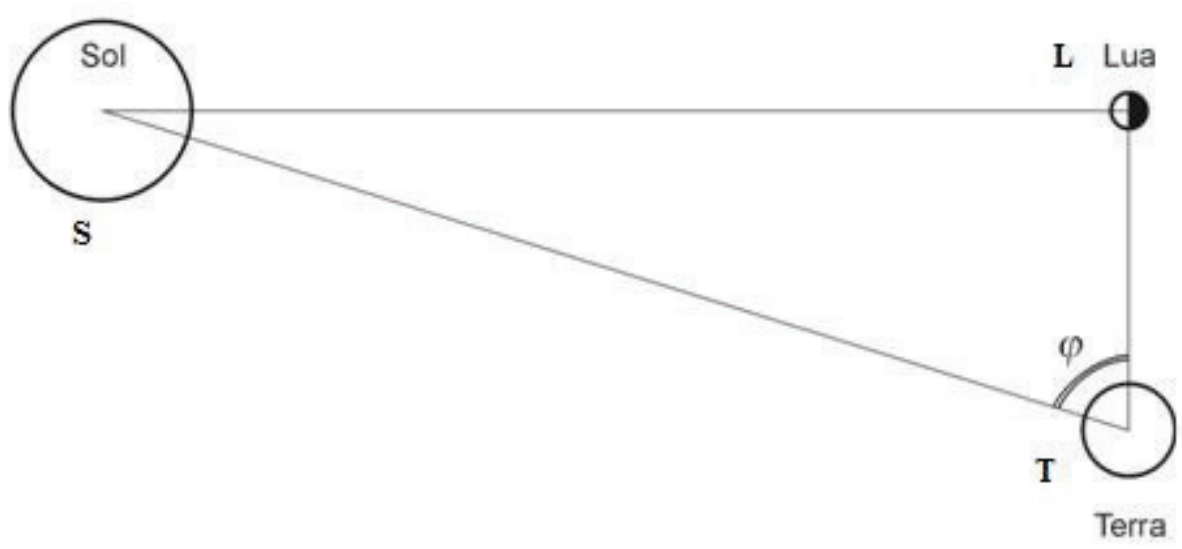

Figura 12. Quando a Lua está na fase de quarto (meio cheia), o ângulo $\varphi$ permite calcular a razão TL/TS.

Na figura 12, a razão entre a distância da Lua e do Sol em relação à Terra pode ser expressa por $\mathrm{TL}=\cos \varphi \times \mathrm{TS}$. Como o ângulo $\varphi$ é, de acordo com a hipótese 4 , igual a $87^{\circ}$, o cosseno de $\varphi$ é igual a aproximadamente 0,0523 , e assim temos TL $=0,0523 \times \mathrm{TS}$. Se assumirmos o valor de TS como igual a 1 , teremos $\mathrm{TL}=0,0523$. A razão TS/TL é, então, igual a aproximadamente 19,12. Aristarco expressa assim a sua conclusão: “A distância do Sol para a Terra é maior do que dezoito vezes, mas menor do que vinte vezes, a distância da Terra [para a Lua]; isso se segue da hipótese sobre a Lua dividida” (HEATH, 1913, p. 353).

O valor medido por Aristarco para o ângulo foi $\varphi=87^{\circ}$, o que faz com que a razão entre as distâncias do Sol e da Lua para a Terra seja de aproximadamente 19. O valor aceito hoje em dia é de $\varphi=89^{\circ} 50^{\circ}$, o que fornece TL/TS $=1 / 389$. Aristarco teria medido o ângulo 
STL com o escafo, apontando o ponteiro para a Lua. Há discordância entre os historiadores sobre se de fato houve uma medição ou uma assunção do valor do ângulo ${ }^{76}$.

Além de calcular a razão das distâncias do Sol e da Lua, Aristarco também calculou a os tamanhos relativos dos dois astros. Para isso, ele se baseou no fato de que, durante um eclipse solar total, o diâmetro angular da Lua é igual ao do Sol. Isso é assim porque, em primeiro lugar, durante um eclipse solar total não se vê o $\mathrm{Sol}^{77}$, o que mostra que o diâmetro angular da Lua não é menor do que o do Sol; e, em segundo lugar, um eclipse desse tipo dura por pouco tempo, o que mostra que o diâmetro angular da Lua não é maior do que o do Sol (EvANS, 1998, p. 69). Na figura 13 (utilizando como base a conclusão anterior de Aristarco) OW, a distância entre a Terra e o Sol, é entre dezoito e vinte vezes maior do que OU, a distância entre a Terra e a Lua. Na figura, o ângulo $\alpha$ corresponde a metade do ângulo subentendido tanto da Lua quanto do Sol; então, se OW é entre dezoito ou vinte vezes maior do que OU, também WX (o diâmetro do Sol) será maior do que UV (o diâmetro da Lua) na mesma proporção. Esta é a segunda conclusão de Aristarco: "O diâmetro do Sol tem a mesma razão [como acima mencionado] para o diâmetro da Lua" (Heath, 1913, p. 355).

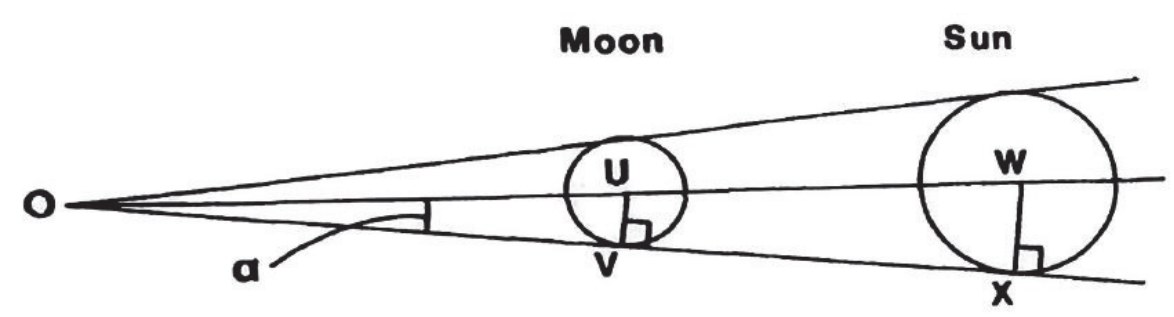

Figura 13. Eclipse solar total e igualdade do diâmetro

angular do Sol e da Lua (Fonte: EVANS, 1998, p. 69)

\begin{abstract}
76 Algumas considerações podem ser feitas a respeito da mensuração do ângulo $\varphi$ : em primeiro lugar, é extremamente difícil, ou mesmo impossível, determinar a olho nu o momento exato em que o Sol e a Lua estariam na condição descrita pela hipótese 3, e mesmo um pequeno erro de tempo para o exato momento da situação da figura 12 poderia levar a um grande erro no ângulo $\varphi$. Em segundo lugar, uma medição com o escafo apontado para a Lua teria sempre uma grande imprecisão, dado que seria necessário apontá-lo para o centro do satélite, e, novamente, pequenos erros na medição gerariam grande diferença no final. Na realidade, o ângulo $\varphi$ na situação da figura 2 é igual a 89 51', e os $2^{\circ} 50^{\prime}$ (entre o valor aceito atualmente e aquele de Aristarco) representam um erro de fator 18 nas razões das distâncias (VAN HELDEN, 1985, p. 7). É justamente esse erro que irá ocasionar a razão $\mathrm{TS} / \mathrm{TL}=19$ - se é que se pode falar em erro, pois, na época e em muitos séculos depois, ninguém tinha uma precisão de $9^{\prime}$, que é a diferença entre os $89^{\circ} 51^{\prime}$ e o ângulo reto. Para um argumento a favor da hipótese da assunção do valor do ângulo, ver EVANS, 1998, p. 72.
\end{abstract}

${ }^{77}$ Ainda que, por vezes, apareça um fino anel de luz solar ao redor da Lua, a chamada coroa. 
Por fim, Aristarco calculou os tamanhos absolutos do Sol e da Lua, e para isso utilizou um diagrama de um eclipse lunar. O desenho da situação de eclipse utilizado por Aristarco tornou-se canônico na história da astronomia e aparece nas dezenas de manuscritos sobreviventes, geralmente fazendo parte de uma coletânea de textos astronômicos, conhecida como "Pequena Astronomia", que presumivelmente serviria de introdução para a "Grande Astronomia" da Syntaxis (Almagesto) de Ptolomeu (HeATH, 1913, p. 317).

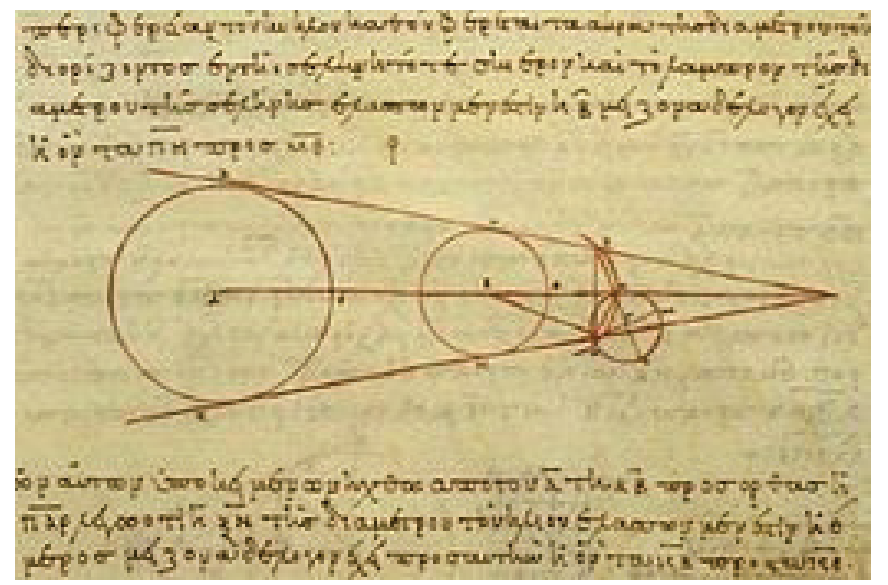

Figura 14. Figura desenhada em um dos manuscritos gregos sobreviventes da obra de Aristarco (fonte: Wikipédia): "o mais velho de todos os manuscritos e de longe o melhor é o lindo Vaticanus Graecus 204, do século X” (HEATH, 1913, p. 325).

O que Aristarco quer demonstrar é que

O diâmetro do Sol tem, em relação à Terra, uma razão maior do que aquela que dezenove tem para três, mas menor do que aquela que quarenta e três tem para seis; isso se segue da razão descoberta entre as distâncias, da hipótese sobre a sombra, e da hipótese que a Lua subentende a décima quinta parte de um signo do zodíaco (HEATH, 1913, 355).

Sigo a apresentação de EvANs (1998, p. 69-71), que, mesmo utilizando a matemática moderna, se mantém mais próxima ao procedimento usado por Aristarco do que a apresentação feita por Thomas Heath.

Antes de iniciar a apresentação, convém introduzir o conceito de paralaxe horizontal. $\mathrm{Na}$ figura 15, um observador na superfície da Terra, no ponto A, que observe o astro B, verá esse astro no horizonte. 


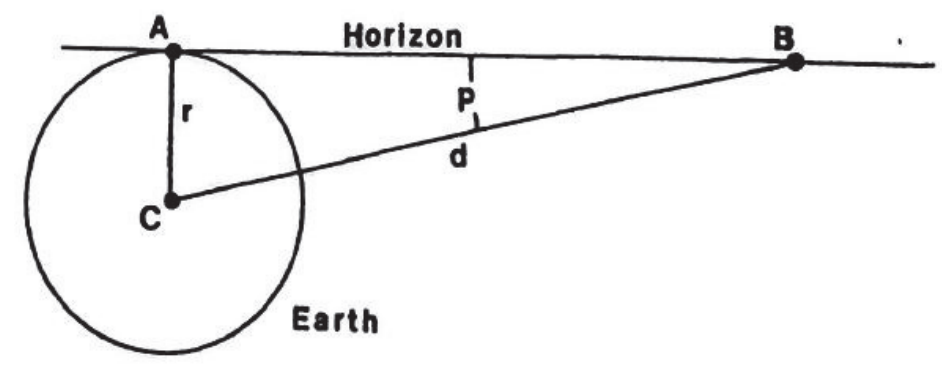

Figura 15. A paralaxe horizontal (Fonte: EVANS, 1998, p. 69)

Se um observador fictício estivesse no centro da Terra, veria o mesmo astro B um pouco mais elevado no horizonte. A diferença angular entre as duas visões é a paralaxe horizontal, marcada como o ângulo P na figura. A relação entre a paralaxe horizontal e a distância d entre o astro B e o centro da Terra pode ser expressa como sen $\mathrm{P}=\mathrm{r} / \mathrm{d}$, onde $\mathrm{r}$ é o raio da Terra. Assim, quanto maior a distância do objeto, menor a paralaxe horizontal.

A situação de eclipse lunar pode ser vista na figura 16. GH é o caminho da Lua através da sombra da Terra durante um eclipse lunar, $\sigma$ e $\tau$ são o raio angular do Sol e da sombra da Terra, pela qual passa a Lua, respectivamente. Como um observador que está em A vê o Sol e a sombra no horizonte, $\mathrm{P}_{\mathrm{S}}$ é a paralaxe horizontal do Sol e $\mathrm{P}_{\mathrm{M}}$, a da Lua. Podemos notar na figura que $\sigma+\tau=180$ - ângulo $\mathrm{XCH}$, da mesma forma que $\mathrm{P}_{\mathrm{S}}+\mathrm{P}_{\mathrm{M}}=180$ - ângulo XCH (já que os três ângulos do triângulo XCH devem completar $180^{\circ}$ ). Se unirmos as duas equações, teremos $\sigma+\tau=\mathrm{P}_{\mathrm{S}}+\mathrm{P}_{\mathrm{M}}$. Como a distância do Sol em relação à Terra é de cerca de 19 vezes a da Lua, a paralaxe horizontal da Lua é cerca de 19 vezes maior do que a do Sol. Assim, temos que $\sigma+\tau=20 \mathrm{P}_{\mathrm{S}}$. 


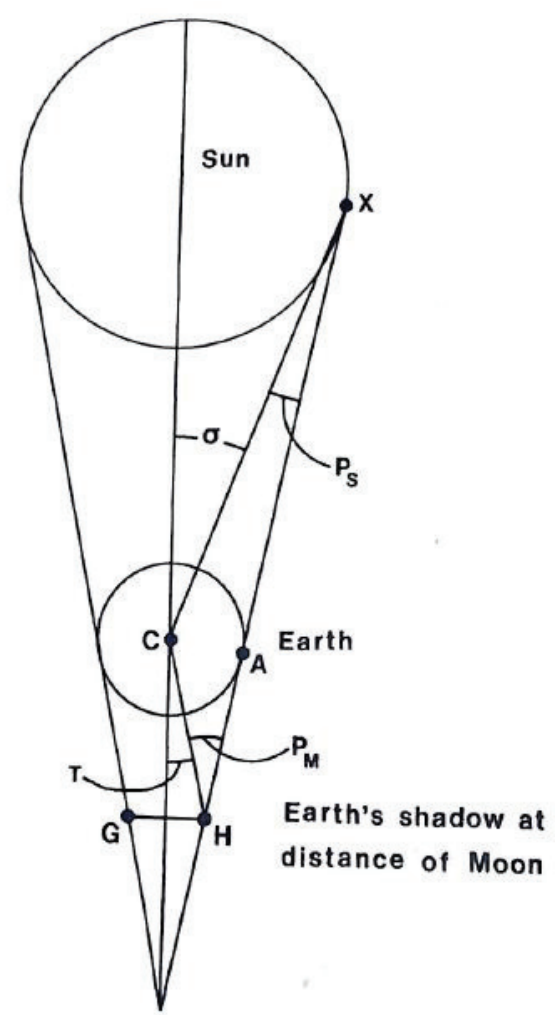

Figura 16. Diagrama do eclipse lunar utilizado por Aristarco para o cálculo das distâncias absolutas (Fonte: EVANS, 1998, p. 69).

A hipótese 5 diz que a "a largura da sombra [da Terra] é [aquela] de duas Luas", o que é plausível em situações de eclipses lunares (ver figura 17).

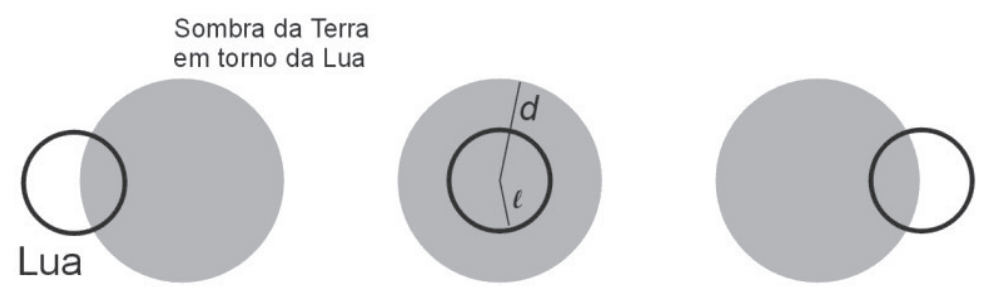

Figura 17. Passagem da Lua pela sombra da Terra durante um eclipse lunar. A quinta hipótese de Aristarco é que $d=2 \ell$.

Então, $\tau$, o raio da sombra da Terra, é igual ao diâmetro de uma Lua. Pela hipótese 6, o diâmetro ângular da Lua é de $2^{\circ}$; assim, $\tau=2^{\circ}$. Dado que a Lua e o Sol têm o mesmo diâmetro angular se vistos da Terra, $\sigma=1^{\circ}$, já que este é o raio angular do Sol (metade do diâmetro). Se esses valores forem substituídos na equação $\sigma+\tau=20 \mathrm{P}_{\mathrm{S}}$, teremos $\mathrm{P}_{\mathrm{S}}=3^{\circ} / 20$. No caso da Lua, como a sua paralaxe horizontal é 19 vezes maior, teremos $\mathrm{P}_{\mathrm{M}}=57^{\circ} / 20$. 
Podemos calcular as distâncias dos dois astros substituindo o valor de $\mathrm{P}_{\mathrm{S}}$ e $\mathrm{P}_{\mathrm{M}}$ na equação da paralaxe horizontal (sen $\mathrm{P}=\mathrm{r} / \mathrm{d})$. Assim, temos que a distância do Sol pode ser dada por $\mathrm{d}_{\mathrm{S}}=\mathrm{r} / \mathrm{sen} \mathrm{P}_{\mathrm{S}}$ e a da Lua por $\mathrm{d}_{\mathrm{M}}=\mathrm{r} / \mathrm{sen} \mathrm{P}_{\mathrm{M}}$, onde $\mathrm{r}$ continua sendo o raio da Terra. Os resultados ${ }^{78}$ são $\mathrm{d}_{\mathrm{S}}=382$ raios da Terra, e $\mathrm{d}_{\mathrm{M}}=20,1$ raios da Terra.

O cálculo do diâmetro absoluto do Sol e da Lua pode ser feito como se segue: na figura 13, vemos que o diâmetro do Sol é igual a $2 \mathrm{WX}$, ou a $2 \mathrm{OW} \operatorname{sen} \alpha$, ou, ainda, que é igual a $2 \mathrm{~d}_{\mathrm{S}} \operatorname{sen} \alpha$. Já que o ângulo $\alpha$ - o raio angular do Sol e da Lua - é igual a $1^{\circ}$, temos que o diâmetro do Sol é igual a 2 (382 raios da Terra) sen 10 , o que dá aproximadamente 13,3 raios da Terra, ou 6,67 diâmetros da Terra. Cálculo semelhante é feito para a Lua, e o resultado é que o diâmetro lunar é igual a 0,351 diâmetros da Terra. O resultado de Aristarco é que o diâmetro solar está entre 6,33 (19/3) e 7,17 (43/6) diâmetros da Terra. No caso da Lua, Aristarco afirma que seu diâmetro está entre 0,398 (43/108) e 0,317 (19/60) diâmetros da Terra (HEATH, 1913, p. 409).

Um ponto que chama a atenção é o uso dos $2^{\circ}$ (a "décima quinta parte de um signo do zodíaco", hipótese 6) como sendo o diâmetro da Lua, quando Arquimedes menciona, no Contador de areia, que Aristarco havia descoberto que "o Sol parecia ser cerca de 1/720 do círculo do zodíaco" (ARQUIMEDES apud EVANS, 1998, p. 71), ou seja 1/20 - e mensurações desse tipo já haviam sido feitas anteriormente, como vimos. EVANS (1998, p. 71) sugere que Aristarco não havia feito nenhuma mensuração quando escreveu sua obra Sobre os tamanhos e distâncias do Sol e da Lua, da mesma forma que não teria medido o ângulo entre a Lua e o Sol. Isso pode sugerir que "na astronomia grega do século III AEC, o método ainda era considerado mais importante do que os próprios números [actual numbers]" (ibidem, p. 72).

Possivelmente, Aristarco escreveu o seu Sobre os tamanhos e distâncias do Sol e da Lua antes de propor sua teoria heliocêntrica. SCHIAPARELLI (1925, p. 422) sugere que uma das causas pelas quais Aristarco se inclinou a colocar o Sol no centro do Universo foi o fato de que o astro era muito maior do que a Terra (entre 6,33 e 7,17 diâmetros da Terra), e parecia “absurdo fazer girar um corpo tão volumoso em torno de um outro tão menor" (ibidem).

Ainda que as ideias heliocêntricas de Aristarco não tenham sido adotadas por seus contemporâneos, sua forma de utilizar a geometria para provar conclusões astronômicas se tornou padrão para aqueles que, após ele, estudaram seriamente os céus. Os cálculos de Aristarco continuaram como o padrão por um século, até que Hiparco aperfeiçoou o diagrama

${ }^{78}$ Como Evans (1998, p. 70) salienta, Aristarco não menciona resultados para as distâncias absolutas do Sol e da Lua, mas eles "seguem-se das suas premissas". 
do eclipse lunar e refez os cálculos, que também foram refeitos posteriormente por Ptolomeu. Os novos desenvolvimentos da matemática, com os epiciclos e excêntricos de Apolônio, junto com o novo tipo de prática astronômica em Alexandria, iriam fazer com que Aristarco caísse no esquecimento, sendo citado como defensor de um sistema fisicamente absurdo. A nova astronomia terá muito mais fenômenos a salvar, e deverá ser preditiva, além de explicativa. Essa nova astronomia também é marcada pela criação de novos instrumentos. Se até Eratóstenes o gnômon (e sua variação, o escafo) é o instrumento mais usado, a partir de Hiparco, e principalmente com Ptolomeu, novos instrumentos serão criados, como o quadrante, o anel equatorial e a esfera armilar (ver EvANS, 1999). "Aristarco é o último filósofo ou astrônomo proeminente do mundo grego que tentou seriamente achar o sistema fisicamente verdadeiro do mundo" (DREYER, 1953, p. 149). 


\section{Capítulo 3}

\section{Modelo causal da astronomia antiga}

Neste capítulo, apresentarei o mapa causal dos avanços da astronomia antiga. Minha intenção é mostrar como funciona o método delineado no primeiro capítulo, utilizando os avanços apresentados no capítulo anterior.

Como vimos no primeiro capítulo, a noção de avanço é puramente formal, e o elemento material advém da pesquisa histórica. Isso significa que cabe ao pesquisador procurar na história da ciência aquilo que considera ser um avanço, ou seja, aquilo que ele acredita exercer efeito causal no desenvolvimento da ciência. Vimos também que a escolha dos avanços dentre a miríade de elementos econômicos, sociológicos, culturais, científicos, etc. - se é que podem ser claramente distinguidos uns dos outros - depende de dois eixos (segundo a sugestão de MiLler [2012, p. 43]): o primeiro é papel causal de fatores intelectuais e não intelectuais na produção do conhecimento, ou seja, em que medida se considera que o desenvolvimento científico é determinado por fatores "internos" ou “externos" à ciência; o segundo eixo é o da finalidade da pesquisa, relacionado com a posição do pesquisador acerca do anacronismo na história e na filosofia da ciência.

Em relação ao primeiro eixo, adotei, no primeiro capítulo, a posição de que ambos os fatores, intelectuais e não intelectuais, influenciam o desenvolvimento da ciência. Isso se manifestou no relato que fiz no capítulo anterior. Procurei mostrar avanços ditos "técnicos", como o sistema de esferas concêntricas de Eudoxo, ao lado de outros mais "filosóficos", como o atomismo de Leucipo e Demócrito, e mais "culturais", como a astrologia judicial babilônica. No entanto, dei ênfase a avanços do primeiro tipo, comuns em histórias da astronomia que adotam a postura que KRAGH (2001, p. 91) chama de história horizontal da ciência. Essa postura tende a se fechar mais na especialidade em questão, enquanto a história vertical da ciência procura inserir a prática científica no contexto mais amplo da sociedade e do tempo em que é desenvolvida. O problema com essa última abordagem é a dificuldade em se obter conhecimento "sobre as causas históricas da situação em análise" (ibidem). No caso da pequena história da astronomia que apresentei no capítulo anterior, tal abordagem faria com que me focasse em tantos aspectos das sociedades babilônica e grega que não poderia dar a devida atenção à astronomia e ao encadeamento de avanços que surgem uns dos outros. 
Minha intenção, ali, era mostrar os avanços que irão ser classificados a seguir, mostrando "por dentro" em que consistiam.

Quanto ao segundo eixo, o da aceitação do anacronismo, afirmei que a MCHC procura evitar os quatro perigos descritos por KRAGH (ibidem, p. 105), mas que algum grau de anacronismo é inevitável - seja na utilização das categorias "ciência", "cientista", "astrônomo", etc., seja na análise filosófica, ao utilizar conceitos como "método", "teoria" e outros que não faziam parte do repertório de ideias utilizadas pelos praticantes da ciência antiga. Por isso, o relato do capítulo anterior é cheio de referências à "ciência" e ao tipo de método utilizado.

O presente capítulo pretende, então, mostrar como os avanços do capítulo anterior se ligam entre si, para, a partir disso, obter algumas intuições sobre a astronomia antiga, tal como praticada até Aristarco. Em primeiro lugar, farei uma classificação dos avanços. Em seguida, mostrarei alguns mapas causais feitos com eles, extraindo nas duas seções algumas conclusões a partir da aplicação da MCHC a esse período da astronomia antiga.

\section{Classificação dos avanços}

A classificação dos avanços depende do período histórico analisado. Isso quer dizer que as práticas científicas mudam, da mesma maneira que as formas de transmissão de conhecimento: em determinado período histórico certos tipos de avanços podem aparecer mais frequentemente do que outros, revelando o tipo de prática científica realizada em uma sociedade ou numa época. Esses avanços, tipificados, podem ser classificados em grupos ou classes de avanços, cuja relação entre si pode indicar as diferentes dinâmicas da ciência para vários períodos. Antes de agrupar os avanços em classes, irei mostrar uma tipificação de cada avanço mostrado no capítulo anterior. Nas duas primeiras colunas da tabela abaixo, são dados o número, o nome do avanço e seu proponente; na terceira, o seu tipo; por fim, na quarta coluna, são feitos alguns comentários sobre as razões para se incluir alguns avanços em uma ou noutra tipificação: 
Avanço Tipo Comentários

\begin{tabular}{cllll}
\hline 1 & $\begin{array}{l}\text { Movimento cíclico dos céus } \\
\text { (Antigos) }\end{array}$ & Observação & \\
\hline 2 & Calendário (Antigos) & Prática cultural & $\begin{array}{l}\text { Nesse avanço se incluem tanto o } \\
\text { calendário } \begin{array}{c}\text { egípcio quanto o } \\
\text { babilônico. Quase todos os povos } \\
\text { antigos confeccionavam calen- } \\
\text { dários. }\end{array}\end{array}$ \\
\hline 3 & $\begin{array}{l}\text { Divisão do dia em 24 horas } \\
\text { (Egípcios) }\end{array}$ & Prática cultural & \\
\hline 4 & Constelações (Antigos) & Convenção & \\
\hline 5 & $\begin{array}{l}\text { Zodíaco com 12 constelações } \\
\text { (Babilônios) }\end{array}$ & $\begin{array}{l}\text { Convenção } \\
\text { (Babilônios) }\end{array}$ & \\
\hline 7 & $\begin{array}{l}\text { Registro sistemático das obser- } \\
\text { vações dos céus (Babilônios) }\end{array}$ & $\begin{array}{l}\text { Prática } \\
\text { metodológica }\end{array}$ \\
\hline 8 & $\begin{array}{l}\text { Astrologia judicial (Babilônios) } \\
\text { Prática cultural }\end{array}$ & \\
\hline 9 & $\begin{array}{l}\text { Sistema numérico de base } \\
\text { (Babilônios) }\end{array}$ & \begin{tabular}{l} 
Linguagem \\
\hline
\end{tabular} &
\end{tabular}

Nesse avanço se incluem tanto o calendário egípcio quanto $\mathrm{o}$ babilônico. Quase todos os povos antigos confeccionavam calendários.

10 Previsão de eclipses (Babilônios) Previsão teórica

A descoberta da regularidade dos eclipses lunares (e solares) pode ser considerada uma predição baseada numa teoria de baixo nível de generalidade. Talvez se pudesse classificar esse avanço como uma "lei empírica".

\begin{tabular}{|c|c|c|c|}
\hline 11 & $\begin{array}{l}\text { Terra plana (Egípcios, Babilônios } \\
\text { e outros povos antigos) }\end{array}$ & Teoria rudimentar & $\begin{array}{l}\text { Nesse avanço se inclui a concepção } \\
\text { de Terra plana tanto dos egípcios } \\
\text { quanto dos babilônios. }\end{array}$ \\
\hline 12 & $\begin{array}{l}\text { Céu semiesférico } \\
\text { Babilônios e ogípcios, } \\
\text { antigos) }\end{array}$ & Teoria rudimentar & \\
\hline 13 & $\begin{array}{l}\text { Retrogradação dos planetas } \\
\text { (Babilônios) }\end{array}$ & Observação & $\begin{array}{l}\text { A retrogradação dos planetas foi } \\
\text { constatada a partir de observações } \\
\text { contínuas. }\end{array}$ \\
\hline 14 & Ciclos planetários (Babilônios) & Observação & $\begin{array}{l}\text { Tal como no caso do avanço } \\
\text { anterior, os ciclos planetários são } \\
\text { descobertos a partir do acúmulo de } \\
\text { observaç̃es. }\end{array}$ \\
\hline $14 \mathrm{a}$ & Anomalia solar & Observação & $\begin{array}{l}\text { Descoberta a partir da constatação } \\
\text { da diferença das durações das } \\
\text { estações. }\end{array}$ \\
\hline 15 & Sistemas A e B (Babilônios) & Teoria rudimentar & $\begin{array}{l}\text { Ainda que muito mais sofisticado } \\
\text { que alguns avanços anteriores (11 e } \\
12 \text {, por exemplo), também } \\
\text { classificados como teorias } \\
\text { rudimentares, esse avanço não pode } \\
\text { ser considerado como uma teoria de } \\
\text { alto nível de generalidade. Seu uso }\end{array}$ \\
\hline
\end{tabular}


é apenas preditivo, e não explicativo.

\begin{tabular}{clll}
\hline 16 & Gnômon (Antigos) & $\begin{array}{l}\text { Instrumento } \\
\text { experimental }\end{array}$ & $\begin{array}{l}\text { O gnômon é o instrumento mais } \\
\text { utilizado na astronomia antiga. }\end{array}$ \\
\hline 17 & $\begin{array}{l}\text { Explicação dos eclipses lunar e explicação de Tales de Mileto } \\
\text { solar (Tales de Mileto) }\end{array}$ & $\begin{array}{l}\text { Explicação de } \\
\text { para os eclipses se baseava no } \\
\text { movimento dos corpos celestes, } \\
\text { que, ao ficarem em determinadas } \\
\text { posições entre si, provocavam os } \\
\text { eclipses. }\end{array}$ \\
\hline 18 & Camera obscura (Antigos) & $\begin{array}{l}\text { Instrumento } \\
\text { experimental }\end{array}$ & \\
\hline
\end{tabular}

Diferentemente do avanço 17, que também é uma explicação, esse avanço é uma explicação que se baseia na natureza dos objetos a serem explicados. Porém, esse avanço pode ser também uma explicação de mecanismo, se

19 A luz da Lua vem do Sol (Tales Explicação de de Mileto) natureza considerarmos que Tales acreditava em tal avanço por causa das posições relativas do Sol e da Lua. Não se sabe como Tales chegou ao conhecimento desses fatos (ainda que seja provável que tenha adquirido esses conhecimentos com os babilônios).

As razões de Anaximandro para a postulação do avanço são de ordem

20 Terra no centro do Cosmos (Anaximandro de Mileto)
Teoria rudimentar lógica: a Terra está no centro porque não tem tendência a cair em nenhuma parte.

Instrumento para marcar o tempo de origem egípcia, foi utilizado por Anaximandro e outros astrônomos gregos na mensuração dos tempos de ascensão dos planetas e das estrelas.

Ainda que não se saiba se de fato Anaximandro chegou a esse avanço, ele deve ter sido alcançado após a suspeita de que o círculo do Sol era oblíquo. Assim, a mensuração é um experimento com o fim de testar uma hipótese.

\begin{tabular}{cll}
\hline 23 & $\begin{array}{l}\text { Identidade da estrela da manhã e } \\
\text { da estrela da tarde (Vênus) } \\
\text { (Pitágoras de Samos) }\end{array}$ & $\begin{array}{l}\text { Identificação } \\
\text { teórica }\end{array}$ \\
\hline 24 & $\begin{array}{l}\text { Harmonia das esferas (Pitágoras } \\
\text { de Samos) }\end{array}$ & Teoria rudimentar \\
\hline 25 & $\begin{array}{l}\text { Salvar os fenômenos (Pitágoras } \\
\text { de Samos, Platão) }\end{array}$ & $\begin{array}{l}\text { Prática } \\
\text { metodológica }\end{array}$ \\
\hline 26 & $\begin{array}{l}\text { Terra esférica (Pitágoras de } \\
\text { Samos ou Parmênides de Eléia) }\end{array}$ & Teoria rudimentar \\
\hline
\end{tabular}


Universo de duas esferas

27 (Pitágoras de Samos, Parmênides Teoria rudimentar de Eléia, Platão)

\begin{tabular}{|c|c|c|c|}
\hline 28 & $\begin{array}{lll}\text { Problema da mudanç } \\
\text { (Parmênides de Eléia) }\end{array}$ & $\begin{array}{l}\text { Problema } \\
\text { filosófico }\end{array}$ & \\
\hline 29 & $\begin{array}{lll}\text { Explicação } & \mathrm{da} \text { obliquidade } & \mathrm{d} \\
\text { eclíptica } & \text { (Empédocles } & \mathrm{d} \\
\text { Agrigento) } & & \end{array}$ & $\begin{array}{l}\text { da } \\
\text { de }\end{array}$ & $\begin{array}{l}\text { Esse avanço é a primeira } \\
\text { explicação, tal qual se sabe, da } \\
\text { obliquidade da eclíptica, que já } \\
\text { havia sido mensurada por } \\
\text { Anaximandro de Mileto. }\end{array}$ \\
\hline 30 & $\begin{array}{l}\text { Atomismo } \\
\text { Demócrito) }\end{array}$ & e Visão de mundo & $\begin{array}{l}\text { O atomismo é considerado uma } \\
\text { visão de mundo, e não uma teoria } \\
\text { geral, por não ser um corpo } \\
\text { estabelecido de leis e princípios, } \\
\text { mas um guia para a pesquisa, } \\
\text { indicando como o mundo é e o } \\
\text { como deve ser explicado. }\end{array}$ \\
\hline
\end{tabular}

\begin{tabular}{clll}
\hline 31 & $\begin{array}{l}\text { Distinção entre qualidades } \\
\text { primárias e secundárias (Leucipo } \\
\text { e Demócrito) }\end{array}$ & Princípio teórico \\
\hline 32 & $\begin{array}{l}\text { Universo infinito (Leucipo e } \\
\text { Demócrito) }\end{array}$ & Teoria rudimentar \\
\hline 33 & $\begin{array}{l}\text { Distinção entre astronomia } \\
\text { meteorologia (Demócrito) }\end{array}$ & $\begin{array}{l}\text { Restrição de } \\
\text { domínio }\end{array}$ \\
\hline
\end{tabular}

34 Teoria da Lua (Anaxágoras de Clazomenae)
Teoria rudimentar

Ainda que Anaxágoras explique vários fenômenos lunares, sua teoria ainda não é capaz de relacionar a Lua com os outros astros.

Este avanço também poderia ser classificado como uma convenção, já que não havia métodos empíricos de determinação da ordem dos planetas.

\begin{tabular}{cllll}
\hline \multirow{8}{*}{36} & \multicolumn{3}{l}{ Unificação da física dos céus e da } \\
Terra (Anaxágoras & de & Teoria rudimentar \\
Clazomenae) & & & \\
\hline 37 & $\begin{array}{l}\text { Universo do } \\
\text { (Filolau } \\
\text { possivelmente } \\
\text { Samos) }\end{array}$ & $\begin{array}{c}\text { Crotona } \\
\text { Sitágoras }\end{array}$ & de & Teoria rudimentar \\
\hline 38 & Movimento circular uniforme & Princípio teórico \\
\hline
\end{tabular}

Esferas homocêntricas (Eudoxo, Cálipo, Aristóteles)
Modelo

representacional / Teoria geral

Este é o princípio teórico utilizado junto com o avanço 25.

Com Eudoxo e Cálipo, o avanço é um modelo que representa o Universo. Aristóteles o transforma num verdadeiro sistema do mundo que explica tudo o que então se conhece.

Tal como no avanço 14, o ciclo metônico foi descoberto através do acúmulo de observações, e era, provavelmente, conhecido pelos babilônios. 


\begin{tabular}{|c|c|c|c|}
\hline 41 & Hilemorfismo (Aristóteles) & Visão de mundo & $\begin{array}{l}\text { Tal como o atomismo, o } \\
\text { hilemorfismo é um guia } \\
\text { (metafísico) para a pesquisa. }\end{array}$ \\
\hline 42 & $\begin{array}{l}\text { Distinção entre física terrestre e } \\
\text { física celeste (regiões sub e supra } \\
\text { lunares) (Empédocles de } \\
\text { Agrigento, Aristóteles) }\end{array}$ & Teoria rudimentar & \\
\hline 43 & $\begin{array}{lll}\text { Cometas e } & \text { Via } & \text { Láctea são } \\
\text { fenômenos } & & \text { atmosféricos } \\
\text { (Aristóteles) } & & \end{array}$ & $\begin{array}{l}\text { Ampliação de } \\
\text { domínio }\end{array}$ & $\begin{array}{l}\text { Aristóteles distinguia a astronomia } \\
\text { da meteorologia, e ampliou o } \\
\text { domínio da última com alguns } \\
\text { fenômenos até então considerados } \\
\text { astronômicos, como os cometas e a } \\
\text { faixa luminosa da Via Láctea. }\end{array}$ \\
\hline 44 & Universo finito (Aristóteles) & Teoria rudimentar & \\
\hline 45 & $\begin{array}{l}\text { Variação no brilho dos planetas } \\
\text { (Polemarco) }\end{array}$ & $\begin{array}{l}\text { Observação / } \\
\text { Anomalia }\end{array}$ & $\begin{array}{l}\text { A observação da variação do brilho } \\
\text { dos planetas torna-se, com } \\
\text { Polemarco, uma anomalia, contrária } \\
\text { ao avanço } 39 \text {. }\end{array}$ \\
\hline 46 & $\begin{array}{l}\text { Rotação da Terra (Heráclides de } \\
\text { Heracléa) }\end{array}$ & $\begin{array}{l}\text { Explicação de } \\
\text { mecanismo }\end{array}$ & $\begin{array}{l}\text { Heráclides explicava o movimento } \\
\text { diário dos céus através do } \\
\text { movimento de rotação da Terra. }\end{array}$ \\
\hline 47 & $\begin{array}{l}\text { Mercúrio e Vênus orbitam ao } \\
\text { redor do Sol (Heráclides de } \\
\text { Heracléa) }\end{array}$ & $\begin{array}{l}\text { Explicação de } \\
\text { mecanismo }\end{array}$ & $\begin{array}{l}\text { Heráclides explicava a variação de } \\
\text { brilho dos planetas através da } \\
\text { hipótese de que Vênus e Mercúrio } \\
\text { orbitavam ao redor do Sol. }\end{array}$ \\
\hline 48 & $\begin{array}{l}\text { Mensuração da circunferência da } \\
\text { Terra (Eratóstenes de Cirene) }\end{array}$ & $\begin{array}{l}\text { Implementação } \\
\text { experimental }\end{array}$ & $\begin{array}{l}\text { Partindo de duas assunções } \\
\text { relacionadas ao modelo do } \\
\text { Universo de duas esferas, } \\
\text { Eratóstenes foi capaz de elaborar } \\
\text { um expediente experimental } \\
\text { (utilizando o gnomon) para medir a } \\
\text { circunferência da Terra. }\end{array}$ \\
\hline 49 & Escafo (Aristarco de Samos) & $\begin{array}{l}\text { Instrumento } \\
\text { experimental }\end{array}$ & \\
\hline 50 & $\begin{array}{l}\text { Mensuração do ângulo entre o } \\
\text { Sol e a Lua na quadratura (Lua } \\
\text { minguante ou crescente) } \\
\text { (Aristarco de Samos) }\end{array}$ & $\begin{array}{l}\text { Observação / } \\
\text { suposição teórica }\end{array}$ & $\begin{array}{l}\text { Como não se sabe se Aristarco } \\
\text { efetuou a mensuração do ângulo, o } \\
\text { avanço pode ser uma observação ou } \\
\text { uma suposição teórica. }\end{array}$ \\
\hline 51 & $\begin{array}{l}\text { Geometria do eclipse lunar } \\
\text { (Aristarco de Samos) }\end{array}$ & $\begin{array}{l}\text { Modelo } \\
\text { representacional }\end{array}$ & $\begin{array}{l}\text { O modelo utilizado por Aristarco } \\
\text { (representado na figura 15) baseia- } \\
\text { se no modelo de Eudoxo, em que a } \\
\text { Lua e o Sol se mantêm a uma } \\
\text { distância fixa da Terra. }\end{array}$ \\
\hline 52 & $\begin{array}{l}\begin{array}{l}\text { Distâncias do Sol e da Lua } \\
\text { (Aristarco de Samos) }\end{array} \\
\end{array}$ & Derivação teórica & \\
\hline 53 & $\begin{array}{l}\text { Tamanhos do Sol e da Lua } \\
\text { (Aristarco de Samos) }\end{array}$ & Derivação teórica & \\
\hline 54 & $\begin{array}{l}\text { Heliocentrismo (Aristarco de } \\
\text { Samos) }\end{array}$ & $\begin{array}{l}\text { Teoria } \\
\text { rudimentar }\end{array}$ & \\
\hline
\end{tabular}


A classificação acima foi feita subjetivamente, com base no que me pareceu ser a melhor descrição para cada avanço. Não pretendo que essa classificação seja exaustiva, e vários avanços poderiam ser classificados de outra forma. A tabela acima contém 24 tipos de avanços, que assim se ordenam segundo a frequência com que aparecem:

\begin{tabular}{|c|c|c|}
\hline Ordem & Tipo & Quantidade \\
\hline 1 & Teoria rudimentar & 14 \\
\hline 2 & Observação & 6 \\
\hline \multirow{2}{*}{3} & Instrumento experimental & 4 \\
\hline & Explicação de mecanismo & 4 \\
\hline \multirow{2}{*}{4} & Prática cultural & 3 \\
\hline & Convenção & 3 \\
\hline \multirow{5}{*}{5} & Prática metodológica & 2 \\
\hline & Modelo representacional & 2 \\
\hline & Derivação teórica & 2 \\
\hline & Visão de mundo & 2 \\
\hline & Princípio teórico & 2 \\
\hline \multirow{13}{*}{6} & Linguagem & 1 \\
\hline & Previsão teórica & 1 \\
\hline & Explicação de natureza & 1 \\
\hline & Experimento simples & 1 \\
\hline & Identificação teórica & 1 \\
\hline & Problema filosófico & 1 \\
\hline & Restrição de domínio & 1 \\
\hline & Ampliação de domínio & 1 \\
\hline & Classificação teórica & 1 \\
\hline & Teoria geral & 1 \\
\hline & Anomalia & 1 \\
\hline & Implementação experimental & 1 \\
\hline & Suposição teórica & 1 \\
\hline
\end{tabular}


A maioria dos avanços é do tipo teoria rudimentar. Por teoria rudimentar entendo "uma teoria ou modelo com conceitos e ideias novas, alguns resultados matemáticos, mas ainda rudimentar" (PESSOA JR, 2000, p. 185). Esse tipo pode ser contraposto ao tipo teoria geral, que é "um corpo organizado de leis gerais, leis empíricas e métodos teóricos" (ibidem). A interpretação de teoria que utilizo é ampla, e representa aqueles avanços que não são detectados diretamente através da observação (que pode ser feita tanto através de instrumentos quanto apenas com os sentidos), mas envolvem algum tipo de elaboração conceitual e postulação de novas entidades e propriedades. Os avanços incluídos no tipo teoria rudimentar podem ter maior ou menor grau de adequação empírica e podem ser derivados de ideias metafísicas, como o avanço 20. Podem também ser mais ou menos sofisticados, desde concepções como a da Terra plana (avanço 11) até os complexos sistemas A e B dos babilônios (avanço 15). As teorias, rudimentares ou gerais, podem passar a explicar mais ou menos fenômenos, num processo de ampliação ou restrição de domínio.

As explicações de mecanismo e de natureza procuram resolver algum problema empírico ou teórico. No primeiro caso (explicações de mecanismo), a explicação é baseada em algum tipo de movimento num sistema, cujas partes, em certas condições, causam o fenômeno em questão. No segundo (explicações de natureza), a explicação é dada em termos da natureza ou das propriedades dos fenômenos a serem explicados. No caso do avanço 19, a explicação se baseia no fato de que a Lua não parece apresentar luz própria (ainda que, como apontei, a explicação possa ser baseada nas posições e movimentos da Lua e do Sol, o que faria com que ela fosse uma explicação de mecanismo). No caso da ciência antiga, torna-se difícil indicar univocamente o tipo de um avanço, dada a escassez de informações sobre os processos de descoberta em muitas situações.

As práticas culturais se referem a avanços que aparecem em várias culturas e não são, necessariamente, científicos, sendo partes de atividades diversas. As convenções são instâncias de representações do mundo escolhidos arbitrariamente, e são utilizados posteriormente como auxílios para as observações ou para a criação de teorias. As práticas metodológicas são modos de realizar a atividade científica, e podem advir tanto de exigências "externas" (como a astrologia [avanço 8], uma das causas do registro sistemático das observações entre os babilônios [avanço 7]), quanto "internas" (como a tradição de salvar os fenômenos [avanço 25], motivada pela filosofia matemática dos pitagóricos). 
Os modelos representacionais são representações geométricas de algum fenômeno, podendo ser utilizados para as derivações teóricas, que utilizam procedimentos dedutivos para a derivação de algum resultado. Uma previsão teórica é aquela baseada em alguma regularidade já conhecida, numa teoria de baixo grau de generalidade ou numa lei natural (por exemplo, o avanço 10). As classificações teóricas são aquelas feitas com o propósito de organizar os fenômenos, e podem ou não ser baseadas na experiência. A identificação teórica ocorre quando duas entidades que até então eram vistas como distintas passam a ser consideradas uma só, como nos casos das aparições matinal e vespertina de Vênus, consideradas dois astros distintos até o aparecimento do avanço 23. Uma suposição teórica é uma assunção plausível e que permite a derivação de resultados (é o caso do avanço 50, se considerarmos que Aristarco não efetuou medições). Os princípios teóricos são princípios utilizados como guias de alguma parte específica da pesquisa científica, diferentemente das visões de mundo, guias amplos, que pretendem abarcar todo o mundo cognoscível. Os problemas filosóficos são problemas metafísicos que podem ser gerados por crises nas visões de mundo, ou podem gerar novas visões de mundo. $\mathrm{O}$ avanço 28 pode, assim, ser considerado uma causa dos avanços 30 e 41 .

Os experimentos simples são feitos para testar alguma hipótese ou melhorar alguma teoria rudimentar. As implementações experimentais são feitas com base em consequências de uma teoria, como no caso do avanço 48, fundamentado em assunções derivadas do avanço 27. As anomalias são tipos de observações que contradizem alguma consequência derivada das teorias. Por fim, a linguagem é o substrato que permite a expressão e comunicação dos resultados científicos. No caso da astronomia antiga, o sistema sexagesimal (avanço 9) facilitou o registro sistemático dos babilônios e moldou a atividade dos astrônomos até os nossos dias, ao utilizarmos esse sistema para as medições astronômicas.

Esses 24 tipos podem ser incluídos dentro de uma classificação baseada em 10 classes de avanços (PESSOA JR. 2000, p. 182): técnica experimental, dados experimentais, desenvolvimento da teoria, trabalho teórico, conceitos \& definições, leis \& fatos, comparação dados-teoria, explicações, problemas \& críticas e, por fim, motivações \& valores. Essa tipologia me parece bastante abrangente, e, embora concebida tendo os inícios da Física Quântica em mente, pode ser utilizada para outros períodos históricos. A base dessa classificação é de origem positivista-lógica, notadamente a visão de que as teorias representam a realidade, através da mediação de regras de correspondência. Ainda que essa visão seja ultrapassada, é útil para uma análise histórica feita dentro da perspectiva da história 
horizontal. Além disso, a inclusão de uma classe de motivações \& valores permite que sejam incluídos na análise justamente aqueles elementos que a visão positivista-lógica desprezava, notadamente os aspectos históricos e sociais das práticas científicas.

As classes técnica experimental e dados experimentais são aquelas que contêm avanços mais próximos da observação e dos experimentos, seja com a pressuposição de alguma teoria a servir como base ou não (não toco aqui no problema da precedência da teoria sobre a observação). A classe desenvolvimento da teoria abrange os avanços nos quais uma teoria é criada e cultivada ou perde força e é abandonada. Já a classe trabalho teórico envolve as "atividades do cientista teórico de aplicar métodos formais para a derivação de resultados e previsões" (PESSOA JR., ibidem). A classe conceitos \& definições contém os avanços que representam os objetos que o cientista irá utilizar em suas teorias, enquanto a classe leis \& fatos contém aqueles avanços que representam descrições do mundo feitas com os objetos teóricos da classe anterior - sendo que essa descrição, quando não possui um aspecto de lei, é colocada na classe explicações. A classe comparação dados-teoria é aquela dos avanços que procuram cotejar os dados observacionais com as previsões ou consequências dedutivas de uma teoria. Os problemas e críticas que uma teoria enfrenta são colocados na classe problemas \& críticas. A classe motivações \& valores contém todos os avanços advindos do (ou fortemente influenciados pelo) meio social em que a ciência é produzida. Ela inclui as práticas culturais, as teses metodológicas, as motivações etc.

Assim, podemos agrupar como se segue os 24 tipos acima:

Teoria rudimentar, Modelo representacional, Trabalho teórico Derivação teórica, Previsão teórica, Identificação teórica, Suposição teórica, Teoria geral, Princípio teórico

Prática cultural, Convenção, Prática

Motivações \& Valores metodológica, Visão de mundo, Linguagem, Problema filosófico

\begin{tabular}{|c|c|}
\hline & 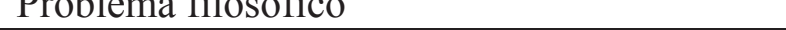 \\
\hline Leis \& Fatos & $\begin{array}{l}\text { Restrição e ampliação de domínio, } \\
\text { Classificação teórica }\end{array}$ \\
\hline Comparação dados-teoria & $\begin{array}{l}\text { Experimento simples, } \\
\text { experimental }\end{array}$ \\
\hline Explicações & Explicações de mecanismo e de natureza \\
\hline Dados experimentais & Observação \\
\hline Técnica experimental & Instrumento experimental \\
\hline Problemas \& Críticas & Anomalia \\
\hline
\end{tabular}


A análise da classificação mostra que boa parte dos avanços da astronomia antiga é da classe trabalho teórico. Se considerarmos teoria no sentido amplo que mencionei, isso se torna compreensível tendo em vista que a astronomia é, no período aqui estudado, uma ciência nascente, e seus conceitos e métodos estão ainda em numa fase inicial. Há apenas uma teoria geral (uma teoria que sirva de explicação global), que é a versão de Aristóteles das esferas homocêntricas. Todas as outras são teorias rudimentares que procuram explicar um ou outro aspecto dos movimentos celestes.

Da mesma forma, a presença de vários avanços da classe motivações \& valores pode ser creditada ao estágio inicial da ciência astronômica na Antiguidade. A escassez de instrumentos experimentais e matemáticos obriga muitos astrônomos a afirmarem suas posições de maneira apenas argumentativa. Essa situação começa a mudar a partir de Aristarco, que, se por um lado é o último dos astrônomos gregos a tentar achar o "sistema fisicamente verdadeiro do mundo" (DREYER, 1953, p. 149), por outro é o primeiro a aplicar o método dedutivo da geometria na astronomia. De fato, a única suposição teórica da classificação é um avanço de Aristarco.

A astronomia antiga sofre a influência decisiva de práticas como a astrologia e a filosofia. A primeira é, entre os babilônios, uma das causas da necessidade de se registrar sistematicamente os movimentos celestes. Como vimos, os registros babilônicos não eram apenas relatos observacionais, mas continham também previsões. Talvez tenha sido esse caráter utilitário, voltado a um fim prático muito bem definido (a astrologia) a fazer com que os astrônomos babilônicos nunca tenham procurado aperfeiçoar seus conhecimentos para além do necessário para produzir boas teorias preditivas. Os sofisticados sistemas A e B dos babilônios não explicam, e nem pretendem fazê-lo, os movimentos planetários que preveem com precisão admirável ${ }^{79}$.

Já a filosofia é uma prática sempre imbricada com a prática (digamos) propriamente científica dos astrônomos gregos. Problemas filosóficos como o de Parmênides ocasionaram o surgimento de visões de mundo que guiaram a pesquisa astronômica, e a própria tradição de salvar os fenômenos, importantíssima na astronomia grega, surge junto com ideias filosóficas acerca da natureza da realidade.

\footnotetext{
${ }^{79}$ O leitor que desejar testar a precisão dos sistemas A e B dos babilônios pode consultar EVANS, 1998, p. 334336.
} 
A presença de apenas um avanço do tipo anomalia ${ }^{80}$ (avanço 45) indica tanto (i) a falta de conhecimento acerca dos processos de transmissão das ideias entre os povos antigos quanto (ii) o estágio de institucionalização da astronomia grega. Em primeiro lugar, não se sabe exatamente, principalmente pela escassez de fontes, como os vários astrônomos adquiriam conhecimento (por exemplo, não se sabe como os gregos receberam as constelações babilônicas). Por isso, os processos de seleção e adaptação - com a consequente tomada de consciência da existência de anomalias - não podem ser devidamente conhecidos. Se os astrônomos antigos negaram certas teorias ou modelos astronômicos de modo semelhante ao caso da rejeição do sistema de esferas concêntricas, não se sabe. Em segundo lugar, o avanço 45 só se torna uma anomalia porque a astronomia já está suficientemente institucionalizada na Grécia a ponto de se tornar uma empresa verdadeiramente colaborativa. Eudoxo foi aluno das principais escolas da Grécia e seus alunos continuaram seu trabalho, inclusive apontando os problemas que poderiam - e, de fato, puderam - causar o abandono de seu modelo.

\section{Mapas causais}

Os avanços e suas ligações causais podem ser representados através do mapa causal. O eixo horizontal do mapa representa o tempo, com os períodos de tempo decorridos indicados na parte de cima. O eixo vertical é uma gradação entre a experiência (ou os aspectos socioculturais) na parte de baixo e a teoria na parte de cima, e é dividido em cinco classes: manifestações culturais, técnicas experimentais, dados experimentais, leis empíricas, teoria específica e teoria geral. Essa divisão é apenas ilustrativa, e seu objetivo é que os avanços sejam sempre mais teóricos à medida que são colocados no alto do mapa. Os avanços são representados por retângulos que contêm o nome, o proponente e a data provável, e as ligações causais são representadas por linhas com setas. Quando há conjunção de causas, usase o conector lógico "\&”, com o símbolo @. Os avanços antagônicos - ou seja, que dizem coisas opostas sobre o mundo - são ligados por linhas duplas terminadas em bolinhas pretas.

Nos mapas, a causalidade que une um avanço a outro é do tipo INUS. Isso significa que cada avanço, dado como causa de outro, é parte necessária de um conjunto suficiente para

\footnotetext{
${ }^{80}$ Não confundir o tipo de avanço "anomalia", que designa um observação que vai contra a teoria vigente, com a expressão "anomalia" usada na astronomia antiga para designar um movimento circular que não seja uniforme, como no termo "anomalia solar".
} 
a produção do efeito. Assim, ainda que haja outras (dentro do conjunto suficiente), as causas que apresento são as mais importantes para mostrar como um avanço causa outro. A atribuição das causas de um avanço é feita seguindo o relato dos historiadores, sempre que possível.

No apêndice, apresento três mapas causais. O primeiro (figura A1) contém os avanços dos egípcios e babilônios, dos primórdios até o século III AEC. O segundo (figura A2) contém a maioria dos 54 avanços listados acima, e representa tanto a astronomia egípcia e babilônica quanto a grega. $\mathrm{O}$ último mapa (figura $\mathrm{A} 3$ ) contém alguns avanços que teriam levado à teoria heliocêntrica de Aristarco.

No mapa da figura A1, há dois avanços "registro sistemático". O primeiro tipo de registro das observações celestes feitas pelos babilônios era mais simples, enquanto o segundo passa a indicar a posição dos planetas com referência às constelações do zodíaco. A astrologia é uma das causas presentes tanto nos primeiros avanços babilônicos, como o "registro sistemático", quanto em outros posteriores, como o "sistemas A e B".

No segundo mapa (figura A2), dois avanços são destacados: o avanço "esferas homocêntricas" e o avanço "heliocentrismo". Enquanto o primeiro vem de uma cadeia causal que tende a ser mais teórica, com avanços na parte de cima do mapa, o segundo vem de outra com avanços também da parte de baixo do mapa, mais observacionais. De fato, a astronomia grega pós-Aristarco - principalmente aquela após Hiparco - passa a ter uma preocupação muito maior em não apenas criar teorias explicativas (sem pretensão de precisão, nos moldes das teorias e modelos geométricos até então produzidos na Grécia), mas em predizer os fenômenos. Essa nova astronomia assume o caráter dado pela obra de Aristarco, com suas provas geométricas e pelos avanços empíricos dos Babilônios. Não é à toa que a astrologia genealógica passe a ser cultivada em centros helenísticos, como Alexandria, justamente com o aporte de métodos e registros babilônicos. Esse movimento culminará na obra de Ptolomeu e na criação de uma nova teoria geral que irá perdurar até o início da modernidade.

O terceiro mapa (figura A3) foca-se nos avanços que teriam levado ao heliocentrismo de Aristarco. Nele, adoto a posição de SCHIAPARELli (1925, p. 422) acerca de uma das causas da mudança cosmológica operada pelo astrônomo grego: movido pelos resultados de seus cálculos dos tamanhos e distâncias do Sol e da Lua, Aristarco teria achado mais conveniente que o Sol ocupasse o centro do Universo, e não a Terra. É de se assinalar que o avanço "Mercúrio e Vênus orbitam o Sol” marca o início daquilo que Schiaparelli considera o segundo estágio das teorias astronômicas gregas: enquanto no primeiro apenas se admite o 
movimento dos corpos celestes ao redor do centro do mundo (em geral a Terra, ainda que os pitagóricos postulassem um Fogo Central), no segundo se admite também os "movimentos circulares em torno de centros diversos" (SCHIAPARELLI, 1927, p. 439). Isso pode ter ajudado a acostumar a mente dos astrônomos gregos com a ideia de que os planetas podem orbitar outros corpos celestes que não a Terra, fazendo com que Aristarco considerasse a hipótese heliocêntrica. Esse mapa pode ser comparado com um outro, ainda por fazer, que mostre os avanços que levaram à adoção, por parte de Copérnico, do heliocentrismo. Isso poderia mostrar em que medida Copérnico foi movido por considerações empíricas (o que configuraria uma crise do sistema ptolomaico, cada vez menos preciso em suas previsões) ou por considerações teóricas. Pretendo abordar esse problema em outra ocasião.

No período histórico aqui estudado, só poderíamos utilizar contrafactuais do primeiro tipo (ver seção 1.3 do capítulo 1), uma vez que não parece haver caminhos históricos alternativos que tenham sido levados em consideração pelos contemporâneos. Essa utilização é trivial. Assim, poderíamos dizer, por exemplo, que sem a astrologia os babilônios não aprenderiam a prever eclipses. Isso porque um avanço como o "registro sistemático" (ver o mapa A1) não teria sido desenvolvido, e o efeito "predição de eclipses" não ocorreria. Com isso, não quero dizer que os babilônios não poderiam chegar a esse último avanço de outras formas, já que de acordo com o esquema INUS, um efeito pode ser alcançado através de vários conjuntos suficientes de causas - mas, como não se conhece caminhos alternativos considerados pelos babilônios, pode-se apenas conjecturar (com mais ou menos cores imaginativas) quais seriam esses conjuntos, e entraríamos no reino dos "contrafactuais de mundos milagrosos", que não me interessam aqui.

\section{Conclusões e perspectivas}

Na presente dissertação, o método da Modelagem Causal em História da Ciência $(\mathrm{MCHC})$ foi apresentado e discutido. Ele foi usado para estudar os primórdios da astronomia babilônica e grega, até o séc. III AEC, de maneira que foi dada ênfase aos diferentes avanços que caracterizaram o período e às relações causais entre esses avanços. Pode-se dizer que esta ênfase em avanços e relações causais já está presente implicitamente no trabalho dos historiadores da ciência, de maneira que o método serve para destacar estas categorias. 
Espera-se que este destaque possa trazer benefícios para o trabalho do historiador e facilitar discussões sobre os tipos de elementos que são introduzidos nos trabalhos historiográficos.

Por outro lado, uma das metas da MCHC é a de ser implementada em linguagem computacional, visando a simulação de histórias possíveis, em que os tempos entre a ocorrência dos avanços variem (em relação ao que ocorreu na história factual), sugerindo assim sequências contrafactuais de avanços. Uma primeira versão deste programa computacional acaba de ser feita por Daniel Marcílio, orientado por Osvaldo Pessoa Jr., e planejo utilizar este recurso para enriquecer a análise da história da astronomia antiga, na continuidade do presente trabalho.

Outro objetivo a ser perseguido, na continuidade do trabalho e extensão do estudo para a astronomia grega até Ptolomeu (e possivelmente até Copérnico), é o de aprofundar a análise das regularidades entre o aparecimento dos tipos de avanços, buscando padrões na evolução detalhada da ciência. Tal estudo poderia ter como meta final auxiliar na comparação entre diferentes metateorias de evolução científica, como as de Kuhn e Lakatos. Nessa linha, uma outra tarefa é a de descrever uma revolução científica, como a de Copérnico, em termos da $\mathrm{MCHC}$, atentando para os méritos e as limitações da presente metodologia (a MCHC talvez tenha dificuldade em dar conta da variação dos significados de conceitos, na passagem de um paradigma para outro).

Um fruto adicional do presente trabalho é o projeto de colocar os avanços da astronomia antiga em um site educativo na internet, com destaque também para as relações causais entre eles. O Apêndice A4 traz uma amostra desta apresentação didática, com três avanços selecionados. Esta lista ilustrada dos avanços já está atualizada, e projeta-se também um banco de informações semelhente para cientistas e locais de trabalho (no caso da ciência moderna, tipicamente as universidades). Tal portal educativo se iniciará enfocando, além da astronomia antiga, também a física do século XIX. 


\section{Apêndice}

Neste apêndice são apresentados os mapas causais citados na seção 2 do capítulo 3, e uma amostra da apresentação didática dos avanços, a ser colocada na internet.

A1. Modelo causal entre avanços: babilônios e egípcios (primórdios até 250 AEC)

A2. Modelo causal entre avanços: astronomia antiga (primórdios até 250 AEC)

A3. Modelo causal entre avanços levando ao heliocentrismo de Aristarco (600 - 250 AEC)

A4. Amostra de avanços da astronomia antiga para apresentação didática (em inglês). 


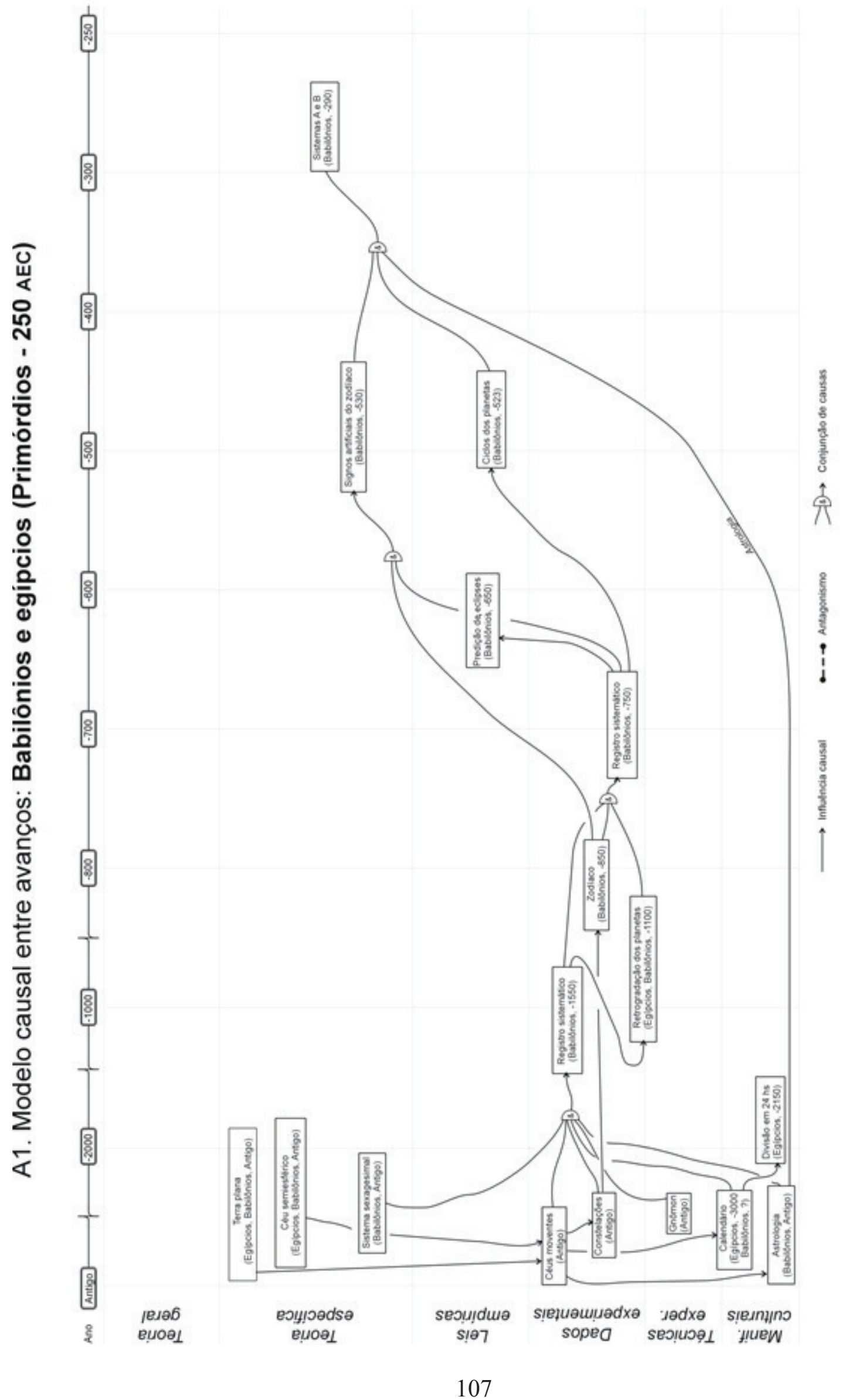




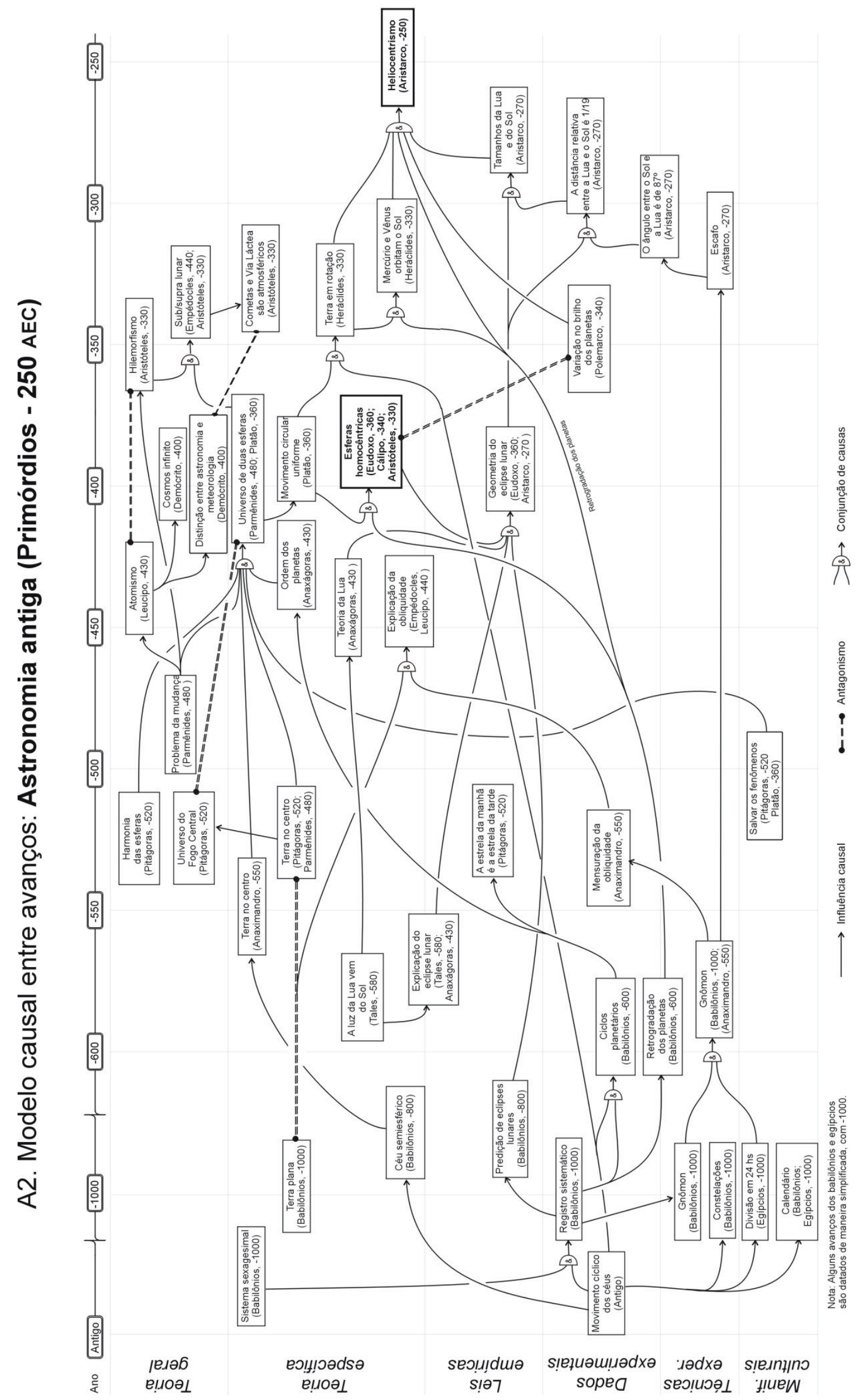




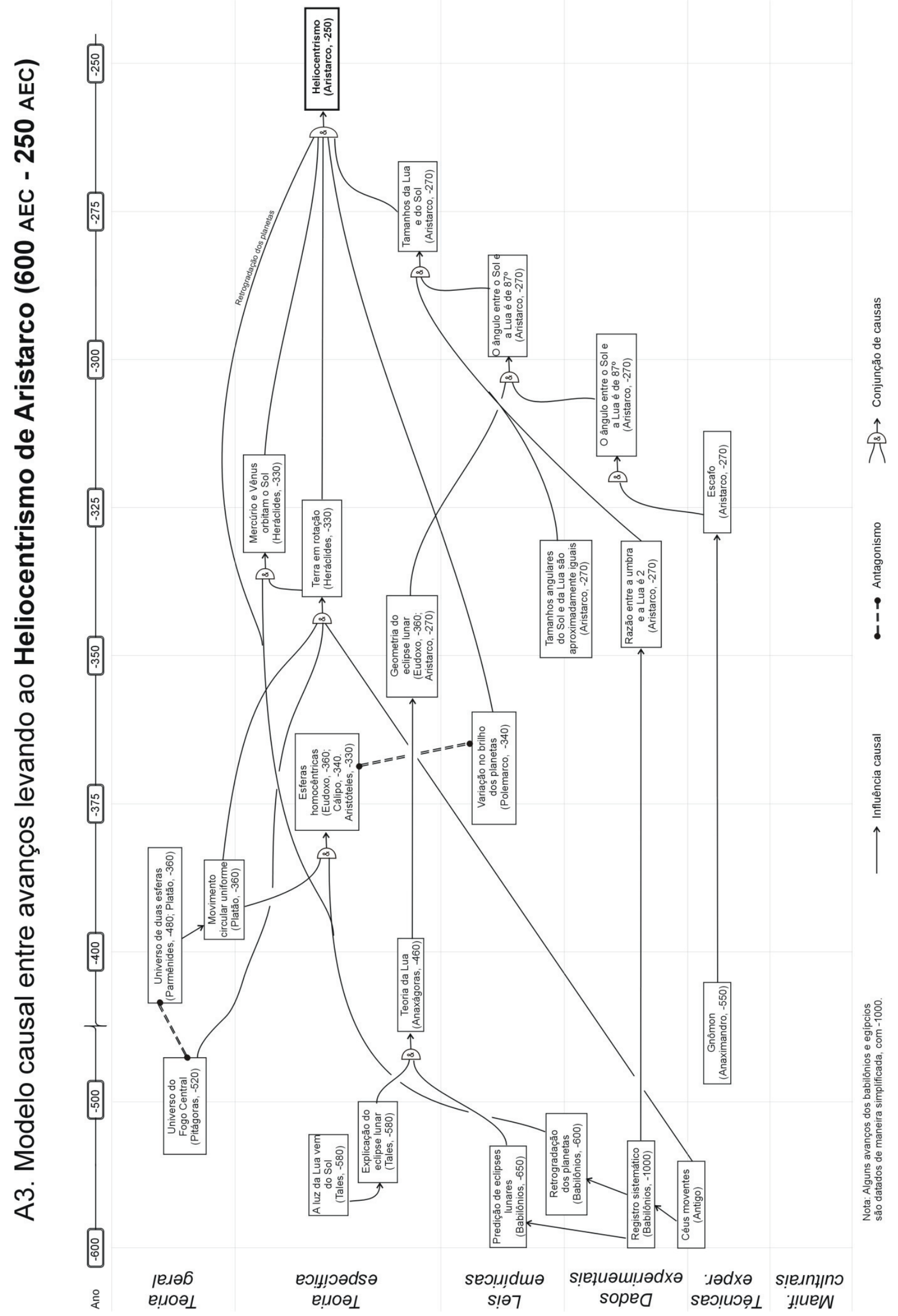




\section{A4. Amostra de avanços da astronomia antiga}

EARTH AS FLAT DISK
rudimentary theory

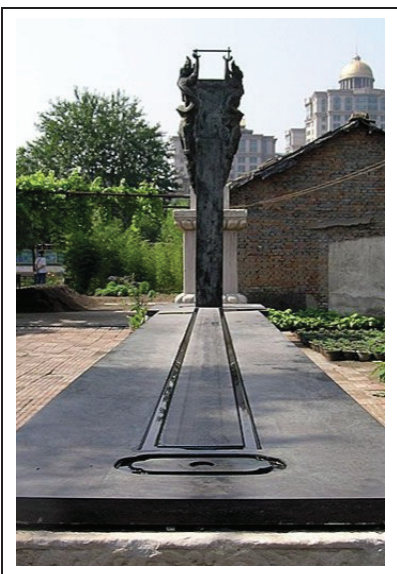

Chinese gnomon based on a model made by Guo Shoujing c. 1300 .

\section{GNOMON \\ experimental instrument}

The gnomon is the shadow stick, part of the sundial that casts the shadow; in Greek, the word means indicator. The Chinese also used the gnomon, mentioned in the 2 nd century as being used earlier by the Duke of Zhou (Wikipedia), while Needham (p. 73) estimates its use from 1500 onwards. Diogenes Laercius (II.1) mentions that Anaximander introduced the gnomon among the Greeks, but it had long before been used by the Babylonians (Herodotus II 109). [Dreyer, 13]

Height of the sun in the winter (lower position) and summer solstice. http://hua.umf.maine.edu/China/astronomy/tianpage/ 0022MingGnomon6471w.html

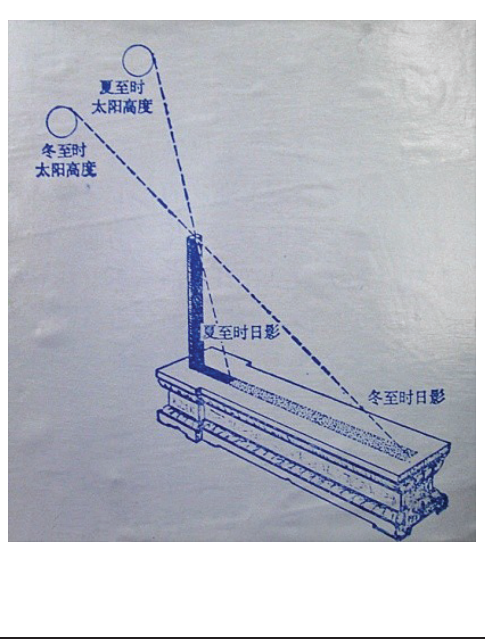

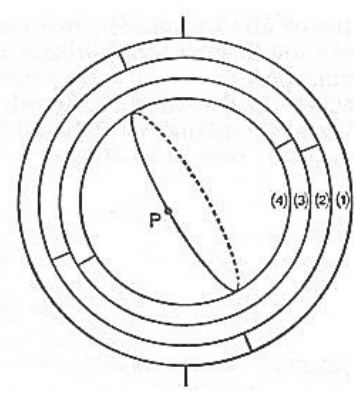

Lloyd, G.E.R. (1970), Early Greek Science: Thales to Aristotle.

\section{HOMOCENTRIC SPHERES \\ representational model}

Each planet is placed upon the inner sphere of a group of a two or more interconnected, concentric spheres whose simultaneous rotation about different axes produces the observed motions of the planets. [Kuhn, 55] Developed by Eudoxus of Cnidus (c. 360 $\mathrm{BCE}$ ), whose system had 27 spheres. Callippus of Cyzicus (c. 340 BCE) was able to solve the problem of the inequality of the seasons, with 34 spheres. Aristotle (c. 330 $\mathrm{BCE}$ ) connected all of them in one big system with 49 spheres.

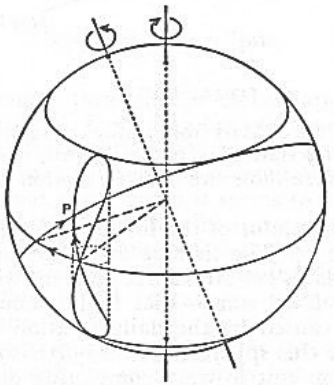

Eudoxus' hippopede (spherical lemniscate). Neugebauer (1953), The

Exact Sciences in Antiquity. 


\section{Bibliografia}

Adorno, F. (1991a), La Filosofia Antica, Volume 1: La Formazione del Pensiero Filosofico dalle Origini a Platone, VI-IV Secolo a. C. Milão: Feltrinelli.

(1991b), La Filosofia Antica, Volume 2: Filosofia, Cultura, Scuole tra Aristotele e Augusto, IV-II Secolo a. C. Milão: Feltrinelli.

Albieri, S. (2010), "Razão e Experiência na Constituição do Conhecimento Histórico Reflexões sobre os Aspectos Indiciários do Paradigma Newtoniano", Dimensões 24: 284-297.

AfricA, T. W. (1961), “Copernicus' Relation to Aristarchus and Pythagoras”, Isis 52, $n^{\circ} 3$ : 403-409.

Aristóteles (2010), On the Heavens. Trad. J. L. Stocks. [S.1]: Forgotten Books.

Barnes, B., Bloor, D., \& Henry, J. (1996), Scientific Knowledge: A Sociological Analysis. Londres: Athlone.

BARton, T. (1994), Ancient Astrology. Londres: Routledge.

Bell, M. (2009), "Hume on Causation", in Norton, D. F. \& TAYlor, J. (orgs.), The Cambridge Companion to Hume. $2^{\mathrm{a}}$ ed. Cambridge: Cambridge University Press, p. 147-176.

Blackwell, R. J. (1969), Discovery in the Physical Sciences. Notre Dame: Notre Dame University Press.

Brannigan, A. (1984), A Base Social das Descobertas Cientificas. Trad. L. S. V. Castro. Rio de Janeiro: Zahar Editores. Original em inglês: 1981.

Chang, H. (2004), Inventing Temperature: Measurement and Scientific Progress. Oxford: Oxford University Press. 
(2012), "Beyond Case-Studies: History as Philosophy", in Mauskopf, S. \& Schmaltz, T. (orgs.), Integrating History and Philosophy of Science - Problems and Prospects. Dordrecht: Springer, p. 109-124.

Collingwood, R. G. (1980), The Idea of History. Oxford: Oxford University Press.

Couprie, D. L. (2011), Heaven and Earth in Ancient Greek Cosmology: From Thales to Heraclides Ponticus. Nova Iorque: Springer.

Donovan, A. (org.) (1988), Scrutinizing Science: Empirical Studies of Scientific Change. Dordrecht: Kluwer Academic Publishers.

Dreyer, J. L. E. (1953), A History of Astronomy from Thales to Kepler. Nova Iorque: Dover. Evans, J. (1998), The History and Practice of Ancient Astronomy. Oxford: Oxford University Press. (1999), "The Material Culture of Greek Astronomy", Journal for the History of Astronomy XXX: 237-307.

Ferguson, N. (1997), Virtual History: Alternatives and Counterfactuals. Londres: Papermac.

Feyerabend, P. (1977), Contra o Método. Trad. O. S. Mota \& L. Hegenberg. Rio de Janeiro: Francisco Alves. Original em inglês: 1975.

Fuller, S. (2008), "The Normative Turn-Counterfactuals and a Philosophical Historiography of Science", Isis 99: 576-584.

Galison, P. (1995), "Context and Constraints", in Buchwald, J. Z. (org.), Scientific Practice: Theories and Stories of Doing Physics. Chicago: University of Chicago Press, p. 13-41.

GARret, D. (2008), "Hume's Theory of Ideas", in RADCLIFFe, E. S. (org.), A Companion to Hume. Oxford: Blackwell, p. 41-57.

George, A. R. (2007), “Gilgamesh and the Literary Traditions of Ancient Mesopotamia”, in LEICK, G. (org.), The Babylonian World. Londres: Routledge, p. 447-59. 
Gingerich, O. (1985), “Did Copernicus owe a Debt to Aristarchus?”, Journal for the History of Astronomy, Vol.16, $n^{\circ} 1:$ 37-42.

Glymour, C. (2001), The Mind's Arrows - Bayes Nets and Graphical Causal Models in Psychology. Cambridge: The MIT Press.

Grant, E. (2002), Os Fundamentos da Ciência Moderna na Idade Média. Trad. de C. G. Barbo. Porto: Porto Editora. Original em inglês: 1996.

Hall, R. J. (1970), "Can We Use the History of Science to Decide between Competing Methodologies?", PSA: Proceedings of the Biennial Meeting of the Philosophy of Science Association, Vol. 1970: 151-159.

Hanson, N. R. (1958), Patterns of Discovery. Cambridge: Cambridge University Press.

(1973), Constellations and Conjectures. Dordrecht: D. Reidel Publishing Company.

HeAth, T. (1913), Aristarchus of Samos: the Ancient Copernicus. Oxford: Oxford University Press.

(1921), A History of Greek Mathematics, Volume I. Oxford: Clarendon Press.

Hegel, G. W. F. (2001), A Razão na História - Uma Introdução Geral à Filosofia da História. Trad. Beatriz Sidou. São Paulo: Centauro. Edição original em alemão: 1837.

Hempel, C. G. (1942), "The Function of General Laws in History", Journal of Philosophy 39: $35-48$.

Herschel, J. F. W. (1831), A Preliminary Discourse on the Study of Natural Philosophy. Londres: Longman, etc.

Hetherington, N. S. (1996), "Plato and Eudoxus: Instrumentalists, Realists, of Prisoners of Themata?", Studies in History and Philosophy of Science 27(2): 271-289.

Hockey, T. (org.) (2005), Biographical Encyclopedia of Astronomers. Nova Iorque: Springer. 
Hoerl C., McCormack, T., \& Beck, S. R. (orgs.) (2011), Understanding Counterfactuals, Understanding Causation - Issues in Philosophy and Psychology. Oxford: Oxford University Press.

Hume, D. (2004), The History of England from the Invasion of Julius Caesar to the Revolution in 1688. The Online Library Of Liberty. Original em inglês: 1778. Disponível em: <http://oll.libertyfund.org/Texts/Hume0129/History/0011-1_Bk.html>. Acesso em 01/08/2012.

(2009), Investigações Sobre o Entendimento Humano e Sobre os Princípios da Moral. Trad. J. O. A. Marques. São Paulo: Unesp. Original em inglês: 1748.

Humphreys, W. C. (1967), "Galileo, Falling Bodies and Inclined Planes - An Attempt at Reconstructing Galileo's Discovery of the Law of Squares", The British Journal for the History of Science 3(11): 225-244.

JARDine, N. (2009), "Philosophy of History of Science", in TuCKER, A. (org.), A Companion to the Philosophy of History and Historiography. Oxford: Wiley-Blackwell, p. 287-296.

Jones, A. (1996), “On Babylonian Astronomy and its Greek Metamorphoses”, in RAGeP, F. J., RageP, S. P. \& Livesey, S. (orgs.), Tradition, Transmission, Transformation: Proceedings of Two Conferences on Pre-Modern Science held at the University of Oklahoma. Leiden: Brill Academic Publishers.

Kelley, D. H. \& Millone, E. F. (2005), Exploring Ancient Skies: An Encyclopedic Survey of Ancient Astronomy. Nova Iorque: Springer.

KIRK, G. S. \& Raven, J. E.(1957), The Presocratic Philosophers: A Critical History with a Selection of Texts. Cambridge: Cambridge University Press.

Kragh, H. (2001), Introdução à Historiografia da Ciência. Trad. C. G. Barbo. Porto: Porto Editora. Original em inglês: 1987.

(2007), Conceptions of Cosmos From Myths to the Accelerating Universe: A History of Cosmology. Oxford: Oxford University Press.

KRUPP, E. C. (2003), Echoes of the Ancient Skies: The Astronomy of Lost Civilizations. Nova Iorque: Dover. 
Kunn, T. S. (1957), The Copernican Revolution: Planetary Astronomy in the Development of Western Thought. Cambridge: Harvard University Press (1977), The Essential Tension. Chicago: University of Chicago Press. (1987), La Teoría del Cuerpo Negro y la Discontinuidad Cuántica, 1984-1912. Trad. M. P. Larrueca. Madri: Alianza Editorial. Original em inglês: 1978. (2001), A Estrutura das Revoluções Científicas. Trad. B.V. Boeira \& N. Boeira. $6^{\text {a }}$ ed. São Paulo: Perspectiva. Original em inglês: 1970.

LACEY, H. (1999), Is Science Value Free? Values and Scientific Understanding. Londres: Routledge.

LAKATOS, I. (1970), "History of Science and Its Rational Reconstructions", PSA: Proceedings of the Biennial Meeting of the Philosophy of Science Association, Vol. 1970: 91-136.

Latour, B. (1998), Ciência em Ação: Como seguir Cientistas e Engenheiros Sociedade Afora. Trad. I. C. Benedetti. São Paulo: Unesp. Original em inglês: 1987.

Latour, B. \& Woolgar, S. (1997), A Vida de Laboratório - A Produção dos Fatos Científicos. Rio de Janeiro: Relume Dumará. Original em inglês: 1979.

Laudan, L., Donovan, A., Laudan, R., Barker, P., Brown, H., Leplin, J., Thagard, P. \& Wykstra, S. (1993), “Mudança Científica: Modelos Filosóficos e Pesquisa Histórica”, Estudos Avançados 19: 7-90. Trad. C. Plastino. Original em inglês publicado em Synthese 69: 141-223, 1986.

LindBerg, D. C. (2002), Los Inicios de la Ciencia Occidental: La Tradición Científica Europea en el Contexto Filosófico, Religioso e Institucional. Barcelona: Paidós. Original em ingles: 1992.

Mackie, J. L. (1962), “Counterfactuals and Causal Laws”, in ButLer, R. (org.), Analytical Philosophy. Oxford: Oxford University Press, p. 66-80. (1965), "Causes and Conditions", American Philosophical Quarterly 2: 245-64. 
MAul, S. M. (2007), "Divination Culture and the Handling of the Future", in LEICK, G. (org.), The Babylonian World. Londres: Routledge, p. 361-72.

MAuskopf, S. \& Schmaltz, T. (orgs.) (2012), Integrating History and Philosophy of Science - Problems and Prospects. Dordrecht: Springer.

Merton, R. K. (1973), The Sociology of Science: Theoretical and Empirical Investigations. Chicago: University of Chicago Press.

Mill, J. S. (1974), Sistema de Lógica Dedutiva e Indutiva. Trad. J. M. Coelho. São Paulo: Abril Cultural. Original em inglês: 1843.

Miller, D. M. (2012), "The History and Philosophy of Science History", in MAuSKOPF, S. \& Schmaltz, T. (orgs.), Integrating History and Philosophy of Science - Problems and Prospects. Dordrecht: Springer, p. 29-48.

Mourão, R. R. F. (1987), Dicionário Enciclopédico de Astronomia e Astronáutica. Rio de Janeiro: Nova Fronteira.

Murcho, D. (2006), “Mundos Possíveis”, in Branquinho, J., Murcho, D. \& Gomes, N. G. (orgs.), Enciclopedia de Termos Lógico-Filosóficos. São Paulo: Martins Fontes, p. 5323.

Neugebauer, O. (1954), "Babylonian Planetary Theory", Proceedings of the American Philosophical Society 98 (1): 60-89.

(1969), The Exact Sciences in Antiquity. $2^{\mathrm{a}}$ ed. Nova Iorque: Dover.

(1975), A History of Ancient Mathematical Astronomy. 3 volumes. Nova Iorque: Springer-Verlag.

(1983), Astronomy and History: Selected Essays. Nova Iorque: Springer-Verlag.

Newall, P. (2009), "Logical Fallacies of Historians", in TUCKer, A. (org.), A Companion to the Philosophy of History and Historiography. Oxford: Wiley-Blackwell, p. 262-273.

Olmstead, A. T. (1938), "Babylonian Astronomy: Historical Sketch”, The American Journal of Semitic Languages and Literatures 55 (2): 113-29. 
OssendriJVer, M. (2012), Babylonian Mathematical Astronomy: Procedure Texts. Nova Iorque: Springer.

PANNEKoeK, A. (1961), A History of Astronomy. Nova Iorque: Dover.

PARKer, R. A. (1974), “Ancient Egytian Astronomy”, Philosophical Transactions of the Royal Society of London 276: 51-65.

PessoA JR., O. (2000), “Histórias Contrafactuais: O Surgimento da Física Quântica”, Estudos Avançados 14 (39): 175-204.

(2006), "Progresso Científico visto da Perspectiva das Histórias Contrafactuais", in STEIN, S. \& KUIAWA, E. (orgs.), Linguagem, Ciência e Valores - Sobre as Representações Humanas do Mundo. Caxias do Sul: Editora da Universidade de Caxias do Sul, p. 165-181.

(2008), "Descobertas Independentes por Caminhos Diferentes: O Caso da Lei da Reversão Espectral (1848-59)", in Martins, R. A., Silva, C. C., Ferreira, J. M. H. \& Martins, L. A. P. (orgs.), Filosofia e História da Ciência no Cone Sul: Seleção de Trabalhos do $5^{\circ}$ Encontro. Campinas: AFHIC, p. 347-356.

(2010a), Contrafactuais e Modelos Causais em História \& Filosofia da Ciência. Tese de Livre Docência apresentada ao Departamento de Filosofia, FFLCH-USP, São Paulo.

(2010b), "Estrutura Causal da Descoberta do Calor Radiante”, in MARTINS, R. A., Lewowicz, L., Ferreira, J. M. H., Silva, C. C., Martins, L. A. P. (orgs.), Filosofia e História da Ciência no Cone Sul: Seleção de Trabalhos do $5^{\circ}$ Encontro. Campinas: AFHIC, p. 474-481.

(2010c), "Modelo Causal dos Primórdios da Ciência do Magnetismo", Scientiae Studia 8: 195-212.

(2011), "The Causal Strength of Scientific Advances", in VIDEIRA, A.A.P. \& Krause, D. (orgs.), Brazilian Studies in the History and Philosophy of Science. Nova Iorque: Springer, p. 223-232. 
— (2013), "Como construir um Mundo Causalmente Possível”, 7 pgs. Submetido ao Manuscrito.

Platão (1997a), Tutte le Opere, Tomo 1: Edizioni Integrali con Testo Greco a Fronte. Vários tradutores. Roma: Newton \& Compton Editori.

(1997b), Tutte le Opere, Tomo 4: Edizioni Integrali con Testo Greco a Fronte. Vários tradutores. Roma: Newton \& Compton Editori.

Polanyi, M. (1962), Personal Knowledge: Towards a Post-Critical Philosophy. Londres: Routledge \& Kegan Paul.

Popper, K. (1975), A Lógica da Investigação Científica. Trad. P. R. Mariconda. São Paulo: Abril Cultural. Original em alemão: 1934. (Coleção Os Pensadores).

Ptolomeu (1984), The Almagest. Trad. G. J. Toomer. Londres: Gerald Duckworth \& Co.

Quine, W. V. (1969), Ontological Relativity and Others Essays. Nova Iorque: Columbia University Press.

RADICK, G. et al. (2008), "Focus: Counterfactuals and the Historian of Science”, Isis 99: 54784.

ReICHenbaCH, H. (1959), Modern Philosophy of Science. Londres: Routledge \& Kegan Paul.

RochBerg-Halton, F. (1991), "Between Observation and Theory in Babylonian Astronomical Texts", Journal of Near Eastern Studies 50 (2): 107-20.

RugGles, C. (2005), Ancient Astronomy: An Encyclopedia of Cosmologies and Myth. Santa Bárbara: ABC-Clio.

Ruggles, C. \& Urton, G. (2007), Skywatching in the Ancient World: New Perspectives in Cultural Astronomy. Colorado: University Press of Colorado.

Russo, L. (1997), La Rivoluzione Dimenticata: Il Pensiero Scientifico Greco e la Scienza Moderna. Milão: Feltrinelli.

SACHS, A. (1974), "Babylonian Observational Astronomy", Philosophical Transactions of the Royal Society of London 276: 43-50. 
Schaefer, B. E. (2006), "The Origin of the Greek Constellations", Scientific American (Nov. 2006): 96-101.

Schiaparelli, G. (1925), Scritti sulla Storia della Astronomia Antica, Tomo I. Bolonha: Nicola Zanichelli Editore.

(1926), Scritti sulla Storia della Astronomia Antica, Tomo II. Bolonha: Nicola Zanichelli Editore.

(1927), Le Più Belle Pagine di Astronomia Popolare. Milão: Ulrico Hoepli Editore.

Selin, H. (2000), Astronomy across Cultures: The History of Non-Western Astronomy. Dordrecht: Springer.

Sismondo, S. (2010), An Introduction to Science and Technology Studies. Oxford: Blackwell.

Steele, J. M. (2000), "Eclipse Prediction in Mesopotamia", Archive for History of Exact Sciences 54: 421-54.

(2008), "Eclipses: Calculating and Predicting Eclipses", in SELIN, H.(org.), Encyclopedia of History of Science, Technology, and Medicine in Non-Western Cultures. Nova Iorque: Springer, p. 734-38.

Swerdlow, N. M. (1998), The Babylonian Theory of the Planets. Princeton: Princeton University Press.

TERESI, D. (2002), Lost Discoveries: The Ancient Roots of Modern Science - From Babylonians to the Maya. Nova Iorque: Simon \& Schuster.

Thurston, H. (1994), Early Astronomy. Nova Iorque: Springer.

Tucker, A. (2009), "Causation in Historiography", in Tucker, A. (org.), A Companion to the Philosophy of History and Historiography. Oxford: Wiley-Blackwell, p. 98-108.

VAN DER WAERDEN, B. L. (1951), "Babylonian Astronomy, III: The Earliest Astronomical Computations", Journal of Near Eastern Studies 10 (1): 20-34.

VAn Helden, A. (1985), Measuring the Universe: Cosmic Dimensions from Aristarchus to Halley. Chicago: The University of Chicago Press. 
Vlastos, G. (2005), Plato’s Universe. Las Vegas: Parmenides Publishing.

WeINRYB, E. (2009), "Historiographic Counterfactuals", in TUCKER, A. (org.), A Companion to the Philosophy of History and Historiography. Oxford: Wiley-Blackwell, p. 109-19.

Whewell, W. (1857), History of the Inductive Sciences: From the Earliest to the Present Time, Vol. 1. Londres: John W. Parker. 